\title{
Ethnicity, Foreign Investments and Strong Pragmatic Government: Towards Interpreting Accounting Progress in Malaysia
}

\author{
Azham Md. Ali \\ Department of Accounting and Finance, Faculty of Management and Economics \\ Universiti Pendidikan Sultan Idris, 35900 Tanjong Malim Perak Malaysia \\ Tel: 015 48117771, Fax: 015 48117295, e-mail: azham@fpe.upsi.edu.my
}

Accepted: August 17, 2014

Doi:10.5296/ jpag.v4i3.6408 URL: http://dx.doi.org/10.5296/ jpag.v4i3.6408

\begin{abstract}
This work applies the interpretive paradigm (Burrell and Morgan, 1979) in understanding the accounting development taking place in Malaysia over a forty year period from 1957 to 1997. To understand accounting in action, the perspective emphasises putting accounting in its particular historical and environmental context and thus leads towards quite rich description of the activity in Malaysia. Following the interpretive approach, accounting here is considered not as a distinct and separable part of the total social system but as an integral to the sociopolitical structure of society (Samuels and Oliga, 1982; Hopwood, 1983; Chua, 1986; Hines, 1988; Morgan, 1988; and Dillard, 1991). This socially constituted view of accounting stresses that accounting is constantly changing and evolving within its dynamic environment. What constitutes the environment surrounding accounting development in Malaysia is comprised of the nation's social, economic and political arenas. Specifically, these environmental dimensions are represented by the following respective factors: ethnicity, foreign investments and strong pragmatic government. These environmental factors which consist of a set of socio-economic relationships and political conditions have the ability to either constrain or facilitate the accounting process. With interpretive research approach and the socially constituted view of accounting adopted in this study, data are obtained from primary and secondary source documentation and from personal interviews conducted with various parties who can be considered as having significant interests in the country's audit practice. From one accounting episode to another that totalled to eight, the impact of ethnicity, foreign investments and strong pragmatic government may be surmised. The factor of ethnicity seems to have shown its impact in the MIA lying low, rejection of the MIA-MACPA merger proposal, activation of the MIA, the rivalry between the MIA and MACPA and finally the setting up of the MASB and FRF. Foreign investments on the other hand appear influential in the establishment of both the MIA and the MACPA, the
\end{abstract}


MACPA thriving during the era of the New Economic Policy (NEP) while the MIA was lying low, and finally in the activation of the MIA later in 1987. As for the environmental attribute of government acting in a strong and pragmatic manner, this may be seen in all episodes except perhaps in the establishment of the MACPA. All in all, it may be inferred that racial concern and the operation of strong pragmatic government in contrast to the influence of foreign investments appear to have constraint progress in the manner that accounting has been developing in Malaysia. Their continuing debilitating impact is expected to continue as long as powerful elite comprising those in the government, corporate and accounting sectors stays intact. Although at one level it appears that changes have actually taken place, deeper analysis shows that much of this change is superficial. Accounting development has been implicated in broader ideological and political struggles in the society (Hopper et al., 1987). Thus, accounting in Malaysia cannot be interpreted as simply a technical phenomenon, but rather as a social activity imbedded in its social, economic and political context. The lessons and experience of the past and present suggest that in all probability the future of accounting in Malaysia will continue to be constrained by unresolved problems. Accounting in Malaysia seems to be a case of "the triumph of hope over experience".

Keywords: Ethnicity, paradigm, accounting process

\section{Introduction}

Burrell and Morgan (1979) claim that all social scientists approach their subject through assumptions about social science and the nature of society. Assumptions about social science or the study of human society can be thought of in terms of the subjective-objective dimension covering the four areas of ontology, epistemology, human nature and methodology. As for assumptions concerning the nature of society, they create another dimension comprised of concerns about the maintenance of social order with regulation and the need for radical change due to deep-seated structural contradictions in society. The placing of these two sets of dimensions together result in four separate views of social theory: radical humanist, radical structuralist, functionalist and interpretive. ${ }^{i}$ The interpretive paradigm which favours the holistic-inductive approach to research is characterised by the intersection of subjective and regulatory dimensions and uses the notion of "understanding" as the method to study human world by reliving the experience of others. As Hopper and Powell (1985, p. 89) put it, "[t]he focus is on individual meaning and people's perceptions of "reality" rather than any independent "reality" that might exist external to them."

Yanow (1994) explains that instead of the discovery of objective facts, the interpretist aims to understand human actions and interactions in their "context" due to his/her view that social institutions, policies, agencies, etc. are human creations, not objects independent of the humans. Also, she explains that the study of human meanings entails the discovery of multiple meanings or varieties of interpretations (by "situated knowers") of the subject of interest ("situated knowns"). The focus accordingly is on the carriers of meanings (known as the artifactual symbols) that come in the forms of symbolic objects, symbolic language and 
symbolic acts. Chua (1986) points out that an interpretist considers "knowledge" to have the following qualities: a high degree of clarity and compatibility with the principles of logic; plausible or common sense meaning derived from parties involved in knowledge creation; and consensually agreed upon by the actors concerned. The last two qualities show that the interpretist perspective recognises diverse understandings and the presence of societal relations entailing the need to attain relevant parties' definitions of situations and analyse how such awareness is intermingled with a wider social, economic and political structure. Thus, the perspective recognises the presence of a relative reality affected by changing social, economic and political environments. It is also concerned with actors' plausible or common sense views woven into a wider environmental context. A theory developed is assessed to be adequate when actors concur with the explanation of their intentions.

In trying to understand the development taking place in the accounting arena in the context of post-independence Malaysia from 1957 to 1997, following the interpretive approach, efforts are undertaken to identify the appropriate environmental context. This subject is discussed next. It is followed by discussion of the research strategies that were conducted in order to come to the "actors' plausible or common sense views." What comes right after is the discussion and analysis of eight episodes considered significant in bringing up the Malaysian accounting establishment to its "cluttered" state by third quarter of 1997 when the nation was becoming gradually affected by the emerging Asian Financial Crisis that began in Thailand in July 1997. The paper ends with the concluding section.

\section{The Environmental Context}

Following the interpretive approach, accounting here is considered not as a distinct and separable part of the total social system but as an integrated aspect of a unified social whole. Accounting in this respect is not understood as "technical" - a neutral set of practices but as an integral to the sociopolitical structure of society. Works in this genre include Tinker (1980), Cooper and Sherer (1984), Armstrong (1985, 1987), Burchell et al. (1985), Hopwood (1985), Berry et al. (1985), Puxty et al. (1987), Miller and O'Leary (1987), Loft (1986), Hoskin and Macve (1986) and Lehman and Tinker (1987). By contextualising accounting in its various aspects, they show accounting to be socially and historically specific. In short, it is a man-made system that is based on socially constructed reality and shaped by its different socio-political and economic environment. It is constantly changing and evolving within its dynamic environment (see Hopwood, 1983; Chua, 1986; Hines, 1988; Morgan,1988; Dillard, 1991; and Samuels and Oliga, 1982). Burchell et al. (1985) lament the neglect by accounting researchers of the intermingling of the accounting and the social. They mentioned (p. 382): “... little is known of how the technical practices of accounting are tethered to the social, of how wider social forces can impinge upon and change accounting, and of how accounting itself functions in the realm of the social, influencing as well as merely reacting to it." As for Puxty et al. (1987) who also lament the lack of emphasis on social context in studying accounting, they argue (p. 273) that a concern with the social context is important if accountants are to understand their position and roles in society and if the significance of accountancy is to be assessed. However, the "context" where accounting is taking place, as pointed out by Tinker et al. (1991), is both complex and conflict-based. 
Willmott (1990) in particular claims that economic factors and market relationships have to be considered together with other elements in the social context such as political programmes and the state-accountant relationship.

Exactly what constitutes the context surrounding accounting in Malaysia has found guidance from many works completed over the years. Indeed, numerous studies have been conducted on the environmental and/or cultural impact upon accounting and related areas in specific nations. These include Flanigan et al. (1994), Hagigi and Williams (1993), Demirag (1993), AlHajjar and Volz (1991), Harston (1991), Hudack (1989), Bloom and Naciri (1989), Foo See Liang (1988), Aguiree and Hagigi (1987), Carmony (1987), Bursal (1984) and Radebaugh (1975). But even after so many decades of research there exists little consensus as to the environmental factors impacting upon nations' accounting practice and professions. Perera (1989, p. 141) Pratt and Behr (1987, footnotes 1 and 2), Radebaugh and Gray (1993, Chapters Three and Four), Meek and Saudagaran (1990, pp. 150-154) and Adhikari and Tondkar (1992) have provided extensive listing of relevant works. Among the well noted works include those of Choi and Mueller (1978), Radebaugh and Gray (1993) and Nobes (1992). Choi and Mueller (1978) subjectively identify fifteen environmental circumstances which may influence financial accounting. These factors may be classified into three social, four political and eight economic (including business) variables. Radebaugh and Gray (1993) on the other hand identify four major environmental groups: educational, socio-cultural, legal and political and economic. Nobes (1992) discusses six factors causing differences in accounting across countries. These are the legal system; types of business organisations and ownership patterns; sophistication of the stock exchanges; tax laws; accounting profession's power base; and finally other forms of influences such as enactment of new laws and military or colonial conquests. In this paper, the selection of elements to constitute the environments has also relied on Smith (1976) who identifies three areas which he claims have the ability to impact a social process: socio-economic, political and cultural factors. The result is as follows: the context surrounding accounting historical development in Malaysia is comprised of the nation's social, economic and political environments. It is submitted that these environments which provide the spatial context within which accounting and for that matter all other activities are taking place are considered to be particularly marked by the following respective factors: ethnicity, foreign investments and strong pragmatic government. (In order to gain better understanding of these specific Malaysian environmental attributes, see also Appendix 1 that provides an historical overview of the country since the $14^{\text {th }}$ century.)

Ethnicity. The multi-ethnic character of the Malaysian population has come into being over the course of the last 150 years. Broadly speaking, the ethnic groups fall into two main categories: those with cultural affinities indigenous to the region known as Bumiputra ("sons of the soil") and those labelled as immigrants whose cultural affinities lie outside (Abdullah Taib and Mohamed Yusoff Ismail, 1982). The multi-ethnic character of the population ensures that there exists linguistic, cultural and religious diversity creating different world-views (Mohd. Taib Osman, 1985). The Bumiputra is comprised of three broad groups: the aborigines, the Malay-related and the ethnic groups residing in Sarawak and 
Sabah. The Malay-related group form a predominant ethnic group in the Malaysian Peninsular, a substantial minority in Sarawak and a smaller group in Sabah. Malays in the east coast of the peninsula, Sarawak and Sabah had long been there before other Malays came to join them from Sumatra and other islands such as Sulawesi in the latter half of 19th century and early 20th century. For all practical purposes, other ethnic groups who settled in the country after 1850 are also regarded as Malays. These include the Javanese, Banjarese, Boyanese, Bugis and Minangkabau who all came from the Malay Archipelago. The Constitution however defines a Malay on a cultural instead of racial terms. That is, a Malay is "a person who professes the Muslim religion, habitually speaks the Malay language, [and] conforms to Malay custom." (See also Syed Husin Ali, 1981, 1965 and Tham Seong Chee, 1983, Chapter One.)

The non-Malay Bumiputra residing in Sarawak has the Iban as its largest group while for Sabah, it is the Kadazan. They and over twenty other ethnic groups represent peoples of the same basic stock who came to the area during the time of Early Migration. They are largely animists although nowadays a significant minority has turned to Islam and Christianity. They make up more than 50 percent of Sarawak's population and about 66 percent of Sabah's. While members of the Malay ethnic group residing in the peninsula originated mainly from the surrounding Malay Archipelago, the immigrant population comprises mainly the Chinese from Southern China (see Strauch, 1986; Laurence K.L. Siaw, 1977; Ting Chew Peh, 1976; and Frankie, 1965) and Indians from Madras and Sri Lanka. The majority of the Chinese are Buddhists or Taoists. As for the Indians where about 85 percent are Tamils, they are divided between Hindus, Buddhists and Muslims. It was the British colonialists who brought in the Chinese and the Indians. Between 1800 to 1941, several million Chinese were introduced to the Malay Peninsular, Sarawak and Sabah to work as miners and merchants. In the early 20th century, thousands of acres of forest had to be cleared for rubber growing, and the Indian Tamils were next imported. Malays constituted 90 percent of the Malay Peninsular population in 1800, but by 1911 they accounted for only about 60 percent. And by the time of independence in 1957, there were more non-Malays than Malays in the Malay Peninsular in the population of 6.3 million (Kennedy, 1993, p. 222).

Tensions among the various races have been serious in the past (see Tan Chee Beng, 1987; Viswanathan Selvaratnam, 1983; von Vorys, 1975; and Chandrasekaran Pillay, 1974). To a good extent this may be viewed to be the outcome of the "divide and rule" tactic of the British colonial administration. This policy ensured that the various ethnic groups generally lived in their own neighbourhoods, followed different occupations, practised their own religions, spoke their own languages, operated their own schools and later formed their own political organisations. The Chinese through their control over retail trade became prosperous, urban middle class. The Malays, being farmers or owning rubber small-holdings, stayed poor and miserable in the villages. The Indians meanwhile were very much left to the mercy of the British rubber plantation owners. Some of these Indians however stayed in towns, working as labourers, clerks and merchants. So, the peoples were separated not just by race and the things they did or where they lived but more crucially by wealth. Even in a homogeneous society, extreme differences in wealth among its members tend to arouse envy 
and conflict. In Malaysia, what made it worse was the fact that the rich and poor were also separated by ethnic origins with the former viewed as immigrants while the latter, indigenous to the region. ${ }^{\text {ii }}$ Thus, Malaysia before and after independence had all the ingredients for social conflict and violence. And racial violence had indeed taken place in May 1969 in Kuala Lumpur. It took place during the time when unemployment was increasing and problem of peasant landlessness continuing (Jomo, 1986, p. 252). The Malays had difficulty in finding jobs and blamed the Chinese who were viewed as discriminatory in their hiring practice and seen (wrongly) as dominating the economy. The Malays were also unhappy with the UMNO-led Alliance government which they viewed to have failed to give sufficient attention to their needs especially in regard to their lack of participation in the modern urban sector of the economy (see Lim Mah Hui, 1988). Malay discontent was compounded by Chinese (and Indian) resentment over what they saw as the government advancing the interests of Malays over other races - e.g. by provision of "special privileges" and ethnic employment quotas (Jomo, 1986, p. 252). Therefore, for both Malays and non-Malays, their dissatisfactions were focused on issues that were basically ethnic in character.

More recently, however, the tensions between the Malays and the Chinese have become less salient. This could be because the country until quite recently was enjoying rapid economic growth in which all races had a share. However, the issue of race is noted here as it appears from documented sources that it remains important even after nearly three decades since the racial riots in 1969 (see Jesudason, 1997; Abraham, 1997; Ravenhill, 1995; Brown, 1994, Chapter Six; Norma Mahmood, 1994; Zakaria Haji Ahmad, 1993; Rigg, 1991, Chapter Six; Chandra Muzaffar, 1989, 1984; and Aliran, 1988b, Chapter One). It seems that, currently and for the foreseeable future, as long as there exist different races with different creeds staying in the country, the issue will never go away completely, although the actual extent to which the racial issue affects the manner in which things are done or occur would probably differ from what has taken place in the past.

Foreign Investments. The influence of the foreign capital can never be underestimated. Jomo (1986, p. 210) notes that there were in existent in the peninsula both local and foreign capital. Both were in competition to affect post-colonial economic development policy to serve their respective interests. However, he points out that the latter "especially [its] industrial capital, has generally been more successful in influencing government policies." The efforts to attract foreign investments were clearly shown within ten years or so after the Malay Federation gained independence in 1957 in the area of companies' operation: taxation. Thus, in its attempt to promote industrial, especially foreign investment in the country, the then government had been accused of providing excessive tax exemptions (David Lim, 1973, p. 261 and Edwards, 1975, Section 5.2). The number says it all: among the limited companies in the manufacturing sector in 1971, the effective rate of direct taxation on profits was 67.6 percent and 39.9 percent for local and foreign companies, respectively; as for all limited companies in 1971, the rates were 59.8 percent and 39.5 percent, respectively (Jomo, 1986, p. 222). And for the ten-year period from 1955 to 1964, the post-tax profitability of British manufacturing companies in the peninsula was substantially greater than that of 
British companies in the rest of the world (David Lim, 1973, p. 264). The subgroup of "other manufacturing" had a post-tax profitability almost three times that for the world as a whole, while the ratio in other manufacturing subgroups, including food, chemical and electrical engineering products, was almost double. All this apparently took place when the rates of reinvestment $^{\text {iii }}$ by foreign-owned companies was much less compared to local-owned companies. Hirschman (1971, pp. 26, 30, Table 6) says that for 1968, Malaysian-owned manufacturing enterprises had a reinvestment rate of 26 percent whereas it was 13 and 12 percent for British and American enterprises, respectively. As for Khor Kok Peng (1979, p. 192, Table 4.4), he reveals that during 1967-72, the reinvestment rates of local and foreign firms were 200 percent $^{\mathrm{iv}}$ and 34, respectively. Lindenberg (1973) discloses the same trend in the late 1960s for local- versus foreign- owned pioneer firms.

The need to attract foreign investments appears to have begun as soon as the country gained its independence from the British in 1957 (Jomo and Edwards, 1993). Jomo (1986, p. 218) mentioned that with a few exceptions, the growth of local manufacturing was effectively discouraged by colonial protection of British manufactures. With the country's independence, the government intensified efforts on increasing manufacturing industries to ensure that foreign exchange could be saved. The government also embarked on the industrialisation drive to avoid the nation's economy being too dependent upon tin and rubber. However, the import substitution strategy of the 1960s was replaced by the government in the 1970s with an export-oriented, labour-intensive industrialisation program. ${ }^{\mathrm{v}}$ The government aggressively promoted the latter through a program of incentives designed to attract foreign investment. Two main types of export-oriented industries were emphasised: first, resource-based industries involving the increased processing of older (eg. rubber and tin) and newer (eg. palm oil, timber) primary commodities for export; and second, electronics, electrical appliances and related equipments. The latter industry was much induced not only by the incentives offered to the foreign private sector, but also by the then movement of multinational enterprises to relocate various parts of their production processes in secure locations abroad offering lower wage and other costs. It involved sources of capitals which were previously not involved in Malaysia. In comparing the two types of industry, the latter has resulted in a far greater growth and employment generation.

While foreign investors have over the years continued to play a crucial role in the nation's industrialisation programme, their influence is not all positive. The weaknesses are particularly apparent in the low level of interindustry linkages and the predominance of a few labour-intensive industries (Anuwar Ali, 1994, p. 716; O'Brien, 1994). The Industrial Master Plan (IMP) unveiled in 1986 for the period 1986-1995 was expected to help in rectifying these weaknesses. Compared to the early years after independence, Malaysia from late 1980s onward took in burgeoning amount of FDI. While the net inflow of FDI into Malaysia averaged RM 200-RM 300 million annually from the 1960s to the early 1970s and hovered around RM 1 billion annually during the period 1974-79 before rising to a record level of RM 3.3 billion in 1982, since 1987 the amount of FDI has shot up tremendously: it was RM 1.1 billion in 1987, RM 1.9 billion in 1988, RM 6.8 billion in 1990 and RM 9.5 billion in 1991 (Lin See Yan, 1994, p. 569). Thus, Edwards (1994, p. 679 and Table 1) has 
pointed out that the role of MNCs was very significant in Malaysia compared to many other developing countries. In terms of the stock of FDI as a percentage of GDP, the rate increased from 25 percent in 1975 to 29 percent in 1985. He also said (p. 687) that even though the New Economic Policy (NEP) (to be mentioned later) had ensured that the share of foreign ownership of the total share capital dropped, ${ }^{\mathrm{vi}}$ by 1990 the book value of foreign shares had actually gone up by more than seven times while their prices rose by about 2.5 times from those in the year 1971.

Until very recently, domestic enterprises played a lesser role in industrialisation compared to foreign private investors. The latter from the time of the colonial administration played a significant role in the manufacturing sector of the country (Anuwar Ali and Wong Poh Kam, 1993; Anuwar Ali and H. Osman Rani, 1987; Raja Tan Sri Mohar Raja Badiozaman, 1979; Wheelwright, 1963). Jesudason (1989) argued that the government's encouragement of foreign investment in especially the manufacturing sector was a strategy to by-pass Chinese capitalists in the Malaysian economy, while Malay interests were to be served by enlarging Malay holdings through public enterprises in the trading, urban property, mining and plantation sectors. Others however mentioned that Malaysia had to rely on foreigners in its industrialisation process since the country was lacking in capital, entrepreneurial skills and technological capability to undertake high-risk industrial activities (Mohamed Ariff and Tan Eu Chye, 1994, pp. 667-68). Furthermore, the FDI ensured overseas market access to the country. The fact that foreigners are viewed to be crucial for Malaysia's industrialisation is a point voiced by numerous interviewees. In addition, they stress that in the 1990s foreigners should be attracted into the country not only because they are needed as in the past to play a significant role in the manufacturing sector, but also because their involvement is needed to promote greater expansion of the capital market as Malaysia hopes to become a regional centre of capital (see also Nor Mohamed Yakcop, 1994 and Abdul Khalid Sahan, 1994).

The Strong Pragmatic Government. The Prime Minister mentions in his writing that being pragmatic is what the leaders in this country believe in (Mahathir Mohamad, 1995). He has also stated that the governing political party has no specific ideology. He writes (Mahathir Mohamad, 1995, p. 13): "At least they cannot be identified with Capitalism, Socialism or Communism .... The only word to describe the political philosophy of the Alliance/National Front is pragmatism. They are always prepared and willing to borrow the differing elements of the current ideologies which in their estimation can help them and the nation they rule." Therefore, in the political field, there is not a liberal democracy as practised in the West. The Prime Minister writes (Mahathir Mohamad, 1995, p. 46): "Malaysian democracy accords the freedom to choose representatives of the people, and by extension, the Government. But it is not a liberal democracy. Certainly, it does not hold itself bound to accept every new interpretation of democracy that comes out of the west." In recent years, the political leaders in Malaysia have proclaimed that liberal democracy as practised in the western countries is incompatible with "Asian values" (see Bilahari Kausikan, 1997; and Joseph Chan, 1997). On the human rights issue in particular, the Prime Minister has mentioned (Prime Minister Speech, 19 May 1995): "Asian human rights need not be a fair copy of Western human rights. The individual and the minority must be allowed their 
freedom but such freedom must not deprive the majority of their rights." Accordingly, human rights as interpreted by the West are rejected because of its belief in the superiority of individual rights to the negation of the rights of the majority.

This is clearly seen in the case of freedom of speech where the Constitution itself says that it may be restricted in legislation "in the interest of security ... (or) public order." Thus, the Sedition Act ${ }^{\mathrm{vii}}$ amendments of 1971, which was passed after the racial riots in May 1969, prohibit public and legislative discussion of a number of issues. Also not surprisingly, in the country, there are laws which allow the government to detain suspects without judicial review or filing charges, such as the Internal Security Act (ISA) of 1960, the Emergency (Public Order and Prevention of Crime) Ordinance of 1969 and the Dangerous Drug Act of 1985. The government justifies the use of these laws to protect the peace and stability of the country and because of its concern over the long-standing racial tensions and endemic narcotics trafficking problems. Nevertheless, the government has also used these laws to detain persons when available evidence is insufficient to bring formal charges under the Criminal Code and more importantly to detain political opponents. When it concerns the press, its freedom is subject to the Printing Presses and Publications Act of 1984 whereby domestic and foreign publications must apply annually to the government for a permit. ${ }^{\text {vii }}$ The Act was amended in 1987 to make the publication of "malicious news" a punishable offence, expand the government's power to ban or restrict publications and prohibit court challenges to suspension or revocation of publication permits. These government prerogatives appear to create an atmosphere which results in much self-censorship among the media organisations of issues the government might consider sensitive. Press freedom appears to be limited too by the fact that leading political figures, or companies controlled by leading political figures in the ruling coalition, own all the major newspapers and all radio and television stations (see Lent, 1984). With freedom of speech and press freedom limited, it may be inferred that the government pragmatic nature is mixed up with that of authoritarian. The presence of a government lacking any apparent fear or respect of other parties in the country and believing in its own righteousness is signified by the following quotation from the writing of the present Prime Minister (Mahathir Mohamad, 1995, p. 52): "There must be a limit to any kind of freedom. And there must be someone to determine when the limit has been reached and to take action to stop it. What better authority than an elected Government to determine and to enforce the limit." Numerous scholars over the years have provided extensive discussion of the meaning of strong state in the context of Malaysia (see Simon and Feraru, 1995; Neher, 1994, Chapter Six; Crouch, 1992; Norma Mansur and Ahmad Nordin Zakaria, 1990; Simon Tan, 1990; Chandra Muzaffar, 1989 - Second Section, 1986; Johan Saravanamuthu, 1987; Mauzy, 1984; and Lim Kit Siang, 1982). By and large, in the political field, it is strong government, mildly authoritarian that is being practised, which in the West is viewed as comprising a high level of restriction over personal, political and intellectual freedom. At the same time that it is autocratic in nature, the government continues to hold regular elections for the people to decide who should govern them. Also there are always opposition parties around with opposition members in the Parliament.

That pragmatism is the all-binding principle is applied not just in the political field. 
In the economic field, the rival philosophies of private- or free-enterprise economy and centrally controlled or planned economy coexist. ${ }^{\text {ix }}$ The Prime Minister writes (Mahathir Mohamad, 1995, p. 20): "Its acceptance of the capitalist free-market system is not total. It is conditional; an adaptation of the system to suit local conditions. In the event it has worked rather well. Still, it continues to be flexible, modifying its practices as it goes along." Thus, the facts are these: there is overwhelming government management of economy and society with the government owning or holding equity in many businesses that operated in the private sector. At the same time, Malaysia, for example, has until recently no foreign exchange control; no limitations on profit remittance or repatriation of capital; and foreign companies are more than welcome. All in all, the Prime Minister has summarised it well of the all-encompassing meaning of a pragmatic government (Mahathir Mohamad, 1995, p. 20): "The absence of rigid ideological tenets frees the Government to do what is practical and beneficial rather than what is ideologically proper. And this it does in the political, economic and social fields."

By and large, the environmental context surrounding the accounting development consists of a set of socio-economic relationships and political conditions that constrain or facilitate the accounting process. By giving emphasis on the context of the accounting development, it fits with the interpretive research approach adopted in this study. This research approach also influences the collection of data that is discussed next.

\section{Research Strategies}

With interpretivism as the line of inquiry, human activity is seen as "text" consisting of a collection of symbols which expresses layers of meaning. "Meanings" people place on the events, processes and structures of their lives are defined by van Manen (1977) as people's "perceptions, assumptions, prejudgements, presuppositions." In getting to these "meanings", the work mainly employs two qualitative research methods: the collection of primary and secondary source materials yielding excerpts, quotations or entire passages and the in-depth interviews asking open-ended questions to allow participants to describe matters freely on their own terms resulting in direct quotations. ${ }^{\mathrm{x}}$ There were also numerous informal talks with a number of people who were at the peripheries of the subject under study to avoid the so-called the "elite bias" (talking only to high-status interviewees). Finally, a set of answers was utilised from an open-ended list of questions sent out to the former finance minister, Tun Daim Zainuddin. Filstead (1970, p. 4) says that the qualitative research approach in no way suggests that the researcher lacks the ability to be scientific while collecting the data. On the contrary, it merely specifies that for validity - and, consequently, for reliability - it is important to try to picture the empirical social world as it actually exists to those under investigation, rather than as the researcher imagines it to be. In the accounting field, numerous scholars argue that qualitative research methods provide rich descriptions of the social world, particularly the meanings attached to actions in the language of actors. In short, they claim that qualitative methods help in understanding how accounting meanings are socially generated and sustained. To mention just a few, these scholars include Humphrey and Scapens (1996), Ryan et al. (1992), Ansari and Bell (1991), Scapens (1990), Covaleski and Dirsmith (1990), Smith et al. (1988), Kaplan (1983, 1984, 
1986), Hopper and Powell (1985) and Hopwood (1983).

With the two qualitative research methods, the basic sources of raw data come in the form of "words", "phrases", "sentences" and "narrations" which can provide a more complete portrayal of this subject under study than "numbers". Blumer (1978) describes "words" and similar data as being capable of providing the "rich", "full" and "real" story, rather than the thin abstraction produced by "numbers". Indeed, these are the data considered appropriate in explaining social aspects which cannot be quantified in a universal manner (Ryan et al., 1992). Thus, what people say is a major source of qualitative inquiry, whether what they say is obtained verbally through an in-depth interview or in written form through a documentary analysis of primary and secondary source materials. The different approaches towards data collection were executed to put into practice the concept of triangulation to reduce systematic bias in research work (see Patton, 1990, p. 470; Miles and Huberman, 1994, p. 266). Interestingly, Neuman (1991, pp. 329-30) has suggested that triangulation is not only to increase the "sophisticated rigor" of the data collection and analysis, but also to help disclose the "richness" of social settings for a qualitative inquiry (see also Kvale, 1996, Chapter 12). He mentions that quantitative researchers would consider the inconsistent picture derived from data on the same social event collected by different methods, different researchers or at different times as "bias" or "error". This he says would not be the case for the qualitative researcher. He writes (p. 330): "But for a qualitative researcher such differences are anticipated and are a valuable source of information about social life. They are themselves an aspect of social life to be analysed."

Documentary Analysis. All the documents referred to lend insight into the perspectives, assumptions, concerns and activities of those who produced them. The primary written materials accessed and analysed in this study comprised mainly the annual reports of the accounting bodies of the Malaysian Institute of Accountants (MIA) and the Malaysian Association of Certified Public Accountants (MACPA) and government documents such as the numerous Malaysian Plans and the texts of speeches of the nation's Prime Ministers. The secondary written sources relied on to provide data on Malaysia's accounting are few and far between. There were conference materials at the ASEAN level where materials on Malaysia's accounting are discussed and a few others at national level. Books on Malaysia's accounting profession are not available except that by Gul (1983) which gives more coverage on accounting education in the country in the early 1980s. Works by Enthoven in the 1970s were also utilised, as were recent materials published in the nation's accounting journals, business magazines and popular newspapers. Needless to say, the last three mentioned sources provide a considerably greater volume of materials than the others mentioned. Also, numerous PhD's theses were referred to deepen understanding on various aspects of the study.

When it concerns the subject of the nation's social, economic and political environments and in particular the respective matters of race, industrialisation and strong pragmatic state, numerous secondary written sources were accessed including various authoritative sources published over the years in and outside of the country. The same was 
done in investigating development in the nation's history and in systems considered to be relevant to accounting process: corporations, government and capital funds. The individual sources are too numerous to be listed here. Those which were referred to extensively are specifically noted within the text or in the endnotes.

It must be recognised that much of the documentary materials provide mere description of what has taken place over the years with little critical or analytical comment. Thus, to borrow phrases made famous by Argyris and Schon (1974), more of "espoused theories" are discovered from these works than really the "theories-in-use" in for example the nation's accounting arena and corporate world. The "espoused theory" is what people say they do; it is the official version of how an organisation such as an MIA or an activity such as accounting operates. The "theory-in-use" is what really happens. Patton (1990, p. 107) mentions that interviewing decision makers and analysing official documents reveal the "espoused theory". Interviewing parties other than decision makers reveals "theory-in-use". This is also why the in-depth interviews described next are considered crucial in this study and that great effort was invested during each interview session - which took place just a few months before Malaysia was caught in the Asian Financial Crisis - for the discovery of "theories-in-use".

In-depth Interviews. The importance of the interviews is expressed well by Merino (1988, p. 188) as follows: "If historians are to provide valid explanations, then we must examine all available evidence, including the testimony of participant sources, to substantiate posited motives and causes" (see also Collins and Bloom, 1991 and Hammond and Sikka, 1996). The interviews took place within a period of six months (from February to July 1997) involving a sample of 31 individuals out of around 150 people and institutions invited to participate. Appendix 2 provides a list of interviewees who comprised individuals from various fields. It is notable that among those interviewed, four were former presidents of the MACPA, one a former president of the Malaysian Chapter of the Chartered Association of Certified Accountants (CACA) and another two at the time of the interview were presidents of international accounting bodies. Also, five members of the MIA council including its vice-president were interviewed. Just like any other qualitative inquiry, there are no rules followed for sample size (Patton, 1990, p. 184). It is viewed that the validity and insights generated have more to do with the information-richness of the individuals and institutions selected and the analytical skills of the researcher than with sample size. Thus, as noted Lincoln and Guba (1985, p. 202), in qualitative inquiry the size of the sample is determined by informational considerations. They write: "If the purpose is to maximize information, the sampling is determined when no new information is forthcoming from new sampled units; thus redundancy is the primary criterion." (Emphasis in the original.)

In short, a purposive sampling approach is used rather than a simple random selection to locate interviewees with the whole aim of attaining information-rich interviews which will illuminate the questions under study. After much effort invested by the researcher, both the accounting bodies, the MACPA and the MIA, gave assistance in identifying some of the people to be contacted. The specific kind of sampling strategy as executed here is what is termed by Goetz and Lecompte (1984) as "reputational case selection" where instances are 
chosen on the recommendation of experts. Though these accounting bodies' assistance is very much appreciated, the majority of the people and institutions contacted were short listed from the examination of the various reading materials mentioned earlier. The selected personalities and institutions were expected to clarify and substantiate the various issues examined by the study on the basis of their direct involvement with the nation's accounting arena. In particular, they were the leaders of the MACPA and MIA, officers from regulatory bodies such as the Registrar of Companies (ROC), the Treasury, the Central Bank and the Kuala Lumpur Stock Exchange (KLSE), other individuals from various chambers of commerce and professionals such as auditors and accountants, bankers, investment analysts and companies' directors. A number of these people may be holding more than one post due to their involvement across organisations. This very fact makes their participation invaluable as they could describe the various matters that they have had to encounter in their various roles. A number of individuals who from the various reading materials could be identified as having opinions on and interest in the nation's accounting were also included. They are those defined by Selltiz et al. (1976, pp. 99-100) as nonindigenous participants and objective observers. For a number of these personalities, their interests on accounting and related matters would be known through the statements that they or other members of the organisations which they were associated with had made through the media, papers presented in conferences, books or article written. This group would include academicians, media personnel and officers from consumer associations.

Prior to the field work, an outline of several areas for discussion were drawn up. From these areas of interest, some specific questions forming the "seeding points" for a wide-ranging conversation were then developed. The interview schedule comprising open-ended type of questions was actually put to use with a considerable degree of flexibility. That is, if an interviewee showed great interest in an issue and wished to develop it further, he or she was encouraged to do so. If on the other hand, he or she was not comfortable to say much or to claim to have little knowledge of the issue forwarded, the question was thus dropped. This led to the possibility that more information would be collected from some people than from others. Patton (1990, p. 286) mentions that for basic research such as the present one where the aim is to understand the holistic overview of a group of people, it is not necessary to collect the same information from each person. In general, the interview guide served as a basic checklist of subject areas to ensure that all relevant topics were covered during the interview. It presumed that there was common information that should be obtained from each person interviewed, but no set of standardised questions was prepared in advance. The wording and the sequence of questions were also adapted to specific participants in the context of the actual interview (see Patton, 1990, p. 283 and Kvale, 1996, Chapter Seven). In regard to the open-ended quality of the questions asked, the aim was to enable interviewees to express their own understanding in their own words. The interviewer never supplied and predetermined the phrases or categories that must be used by respondents to express themselves. The focus was on learning interviewees' viewpoints by recording their terminology and judgements and capturing the complexities of individual perceptions and experiences. As Patton (1990, p. 278) notes succinctly, the purpose thus is to allow the interviewer to enter into the participants' perspective using the assumption that the 
perspective of others is meaningful, knowable and able to be made explicit.

Not having a structured interview format is viewed to be a more effective way of establishing a better understanding of accounting development within its historical and environmental contexts, due to among other things the implicit assumption behind the use of structured interviews that questions and responses are taking place in a context-free framework. Utilising structured interviews would also prevent participants from posing their own questions and introducing lines of inquiry not envisaged by the researchers. Nevertheless, there are limitations with semi-structured, open-ended interviews. This is because of the tendency of certain individuals (even when it is agreed that they are not going to be directly identified in the report for certain views they expressed) to exhibit opinions that are "politically acceptable" to others. Moreover, this type of interviews does not negate the possibility that participants adopting a manipulative stance and, deliberately or otherwise, feed information for power-related or political purposes to the researcher (see also Van Maanen, 1979). During the field work, the researcher in more than a few times experienced a number of these limitations of semi-structured interviews. As a result, he was forced to look for ulterior motives of the interviewees when such data were collected to make sure that specific interventions were executed.

Douglas (1976) discusses various intervening steps that an interviewer could undertake in facing people in field sites who nearly always have reasons for omitting, selecting or distorting data and for deceiving the field worker (not to mention deceiving themselves). A number of these steps can be executed during field work, including sharing knowledge of "what's going on" and seeing whether the respondent concurs and summarising a state of affairs and then asking the interviewees to deny it. Bronfenbrenner (1976), Guba (1981) and Stake (1976) consider giving "feedback to informants" to be an important step. This effort often however discovered differences in stories narrated. But as Miles and Huberman (1994, p. 276) put it succinctly: "Don't expect that informants will always agree with you or with one another. If they always did, life at the site would be more conflict free than you probably found it to be. People often have widely varying perceptions of the same phenomenon." Note also that Miles and Huberman (1994) provide an extensive discussion on enhancing the validity and reliability of field data. A number of these tactics were in fact implemented during the field work including continuous probing during the interview sessions and triangulation of views from several different sources.

The majority of the interviews took from one and a half to two hours to complete. Also, the majority were recorded on tapes though in most cases sections of the interviews were left untaped for the interviewees had asked for that to be the case. Except in one case where the latter half of the interview was conducted at one of his residences, the rest of the interviews were conducted in either the interviewees' offices or the organisations' conference rooms. In three cases, the interviews were conducted with two interviewees each. In two cases, the interviews were conducted in two separate sessions. During the interviews, little note-taking was undertaken to ensure full concentration on the matters being discussed. But within the next twelve hours after most interviews, a summary and reflection of what had taken place was prepared by talking to the tape recorder. Full-length summaries interspersed with quotes 
where necessary were prepared for each interviews later on. The objective everytime was to retain as much as possible the essence of the original data of "accounting in action". Nevertheless, it is readily admitted that one concern with this type of data gathering is the loss of data through taping and producing a summary.

The study of a complex phenomenon such as this one on accounting development in its historical and environmental contexts demands in-depth and detailed research work in and out of field. The decision to adopt the qualitative research methods fits not just with the interpretive research paradigm, but also with the everyday reality of human life marked by various complications, struggle and whatever other specifics. By and large, the interpretive framework aided by qualitative data is most appropriate for examining a nation's accounting development because it recognises that accounting is a cultural product, not a natural phenomenon.

\section{The Accounting Impact of Ethnicity, Foreign Investments and Strong Pragmatic Government}

Over the years, numerous developments have taken place in the nation's accounting field. From both interviews and documented sources, those considered significant are (in the order of their discussion next):

- The establishment of the MIA through the passing of the Accountants' Act 1967;

- The forming of MACPA under the Companies Ordinance 1940 as a company limited by guarantee in July 1958;

- The MIA lying low in the 1970s and which went on in the 1980s until its first AGM in 1987 ;

- The MACPA thriving throughout the time when the MIA was inactive;

- The rejection of the proposal for "merging" the MIA and the MACPA by the federal cabinet in June 1985;

- The activation of the MIA with its first AGM in September 1987;

- The rivalry between the MIA and MACPA during the first decade of an active MIA;

- The setting up of the Malaysian Accounting Standards Board (MASB) and its parent body the Financial Reporting Foundation (FRF) with the passing of the Financial Reporting Act 1997.

Each one of these eight historical episodes is analysed next to check the impact of the social (ethnicity), economic (foreign investments) and political (strong pragmatic government) factors that surround the accounting development.

The Establishment of the MIA. When the Malaysian Parliament passed the Accountants Act 1967 in September that year, the MIA came to existence as a statutory body. Section 6 of the Accountants Act notes five functions of the MIA including the responsibility to regulate the practice and to promote the interests of the profession of accountancy and to determine the 
qualifications of persons for admission as members. The Act resembled the Singapore Society of Accountants Ordinance 1963 which in turn was based upon the New Zealand Society of Accountants Act, the main difference being that the Malaysian Act was "much briefer" and thus "less explicit" than the Singaporean Ordinance (Goh Joon Hai, 1970/71, pp. 27-28). The MIA 1967-1987 Annual Report (p. 14) showed that the head of the MIA named as its chairman was D. Mortimer who was "elected" on 22 November, 1967. The following year on 31 May, 1968 Dato' Shamsir Omar who was the then Accountant-General was appointed as the president of the MIA. ${ }^{\text {xi }} \mathrm{He}$ who went on to hold the post of Accountant-General for 21 years until July 1989 had also acted as the MIA president until 9 April, 1987 when Haji Hanifah Noordin took over the post.

Also, in the MIA 1967-1987 Annual Report (p. 9), it was noted that the reason behind the establishment of the MIA by the government involved the need to have a local body "to regulate and control the practice of the accountancy profession and to ensure that only suitably qualified persons are admitted to the profession." It appeared that the government was aware that such a body was essential since a lot of individuals calling themselves accountants or practising public accounting in the years following independence had a variety of educational backgrounds and qualifications. The House of Representatives' Parliamentary Debates (Vol. IV, No. 12, Col. 2409 dated 25 Aug. 1967) had disclosed the following remark made by the then assistant minister of finance, $\mathrm{Dr} . \mathrm{Ng}$ Kam Poh:

The position of the accountancy profession in Malaysia at present is not entirely satisfactory in that although many accountants are members of long established and reputable associations and have within the last few years between them formed the Malaysian Association of Certified Public Accountants for the purpose of maintaining adequate standards of competence and ethics in this country, there are many who wish to be considered as accountants but who belong to accountancy associations imposing lower standards or whose members could be considered under qualified except for a measure of practical experience.

Next he stated that the objective of the Bill was to make provision for the adequate control of the accounting profession as a whole, and this control was to be entrusted to the MIA to be established under the Bill. In particular, the MIA is required to maintain a register of accountants. Reference made to the Accountants Act 1967 shows that those who are not registered members would be found to have transgressed Sections 22 and 23 when they hold themselves out as public, registered or licensed accountants or adopt, use or exhibit these titles or others such as auditors, tax consultants and tax advisers. ${ }^{\text {ii }}$, ${ }^{i i}$ Any transgression would mean the person is liable for a fine maximum RM 1000 or imprisonment for up to one year for the first offence and with subsequent transgression he or she is liable for a fine maximum RM 2000 or imprisonment of two years. In the ensuing debate, it appears that high hopes were placed by other Parliamentarians on the MIA. For example, an MP from Bukit Bintang, Tan Toh Hong, prior to his giving a rather long speech of the essential 
functions played by accountants in the nation's economic development, mentioned the following: "The long-felt need to register accountants and control the profession is at last being fulfilled." And in the middle of that speech he mentioned "... Sir, this Bill is timely, and I am sure that when this Bill comes into operation, the standard and quality of accountants in Malaysia will always be safeguarded." And he ended his speech by saying "[w]ith the passing of this Bill, I am sure, that our society will continue to be assured of better services from well-qualified and trained accountants."

The Forming of the MACPA. The MACPA is the only local accounting body whose members were recognised under the Accountants Act 1967. The Malaysian Society of Incorporated Accountants or its other name the Malaysian Society of Accountants (MSA) was excluded, but its members at the time the MIA was formed in 1967 were issued licenses under the Accountants Act and were thus licensed accountants. The MACPA was established through the initiative of the private sector. In less than a year after the independence of the Malay Federation, on 26 July 1958, twenty local accountants who were formerly members of the Malayan branch of the Association of Chartered and Incorporated Accountants (ACIA) and the Malayan branch of the Association of Certified and Corporate Accountants (ACCA) came together and incorporated the Malayan (later Malaysian) Association of Certified Public Accountants (MACPA) in Singapore under the Straits Settlement Companies Ordinance 1940 (CERPASS, Dec. 1967, p. 51). The MACPA was set up as a company limited by guarantee with the objective of advancing the status and development of the accounting profession in Malaysia and to provide the opportunity to those aspiring to qualify as an accountant to be trained under local law and practice (The Malaysian Accountant, July-Sept. 1988, p. 16). Thus, to satisfy that latter objective, the MACPA in February 1961 instituted the examination and articleship system of training accountants and registered its first batch of students (The Malaysian Accountant, July-Sept 1988, p. 10). The first MACPA examination - "Intermediate" - was held in December 1963 and the other two "Final Part I and II" - in December 1965. All took place with the assistance of the Overseas Accountancy Examination Advisory Board (OAEAB) established by the Chartered Accountants Joint Standing Committee of the Institutes of Chartered Accountants of Scotland, England and Wales and Ireland. This support by the OAEAB was extended until 1969 (Enthoven, 1977, p. 323). ${ }^{\text {xiv } x v}$ As for the training program, a student must sign a training contract for a period of three or four years with a member of the MACPA in public practice (Abu Hassan Kendut, 1986, pp. 4-5). During the training contract the student worked in the office of the MACPA member. He or she was paid a salary and other allowances in the form of textbooks, paid study leave, and examination and tutorial course fees.

The first three presidents of MACPA were westerners. They were R.D. Stewart (1958/59) from the audit firm Turquand, Youngs \& Co, W.M. Piercy (1959 to 1961) from Evatt \& Co. in Singapore and H.R. Villiers (1961/62) from Peat, Marwick, Mitchell \& Co. in Kuala Lumpur (MACPA 1977 Annual Report, p. 3). The next five included four Chinese Malaysian and a British - Fred Weatherly - who has a permanent resident status. The first Malay to become president of the MACPA, after nearly a decade of presidents who were British and Chinese Malaysian, was the late Datuk Abdul Razak Yusof for the years 1967 to 
1969. MACPA was modelled upon the ICAEW and is a good example of those accounting professional bodies described by Parker (1989) as following the British institutions of professional accountancy. Said Dr. Nawawi Mat Awin (The Malaysian Accountant, Jan. 1981, p. 45): "Besides examinations, the founders of MACPA drew extensively on the experience of the English Institute in establishing the foundations of the profession, particularly in professional education, standards and discipline." Perhaps all of this was inevitable. As stated by the Committee on International Accounting Operation and Education, 1976-78, of the American Accounting Association (1978, p. 72), "[w]hen there is no accounting profession, the [developing] country usually looks to its former colonial motherland for a model." The very fact that the MACPA was modelling in particular its examination and training scheme upon that of the ICAEW was noted by Megat Abdul Rahman, the then vice-president of the MACPA (Megat Abdul Rahman, 1980, p. 3). He stated that "[i]n Malaysia, the 'articleship' system (now known as Stream I) is a direct copy of that of the English Institute." He also reveals (p. 2) that "[t]he MACPA education structure was inevitably based on the English Institute of Chartered Accountants (ICAEW)."

Discussion. The fact that the Malaysian society right after the gaining of independence in 1957 was in need of quality services from qualified accountants was never in any doubt. This need emerged due to the policy of the then government to manage the economy in the same manner as that of the former British colonial rulers. ${ }^{\text {xvi }}$ In other words, there was no nationalisation of the business operations of the British and other foreigners. In fact, much of the profits garnered from rubber plantations and tin mining operations continued to be channelled to UK and other foreign investors. The numbers say it all of what took place before, a few years after and at independence in the nation's modern economy - where the corporate sector was dominated by rubber estates and tin mines whose owners were European, predominantly British (Vreeland et al., 1976, p. 337) and where the concerned publicly owned companies were managed by merchant agency houses (Kennedy, 1993, p. 206; Junid Saham, 1980, Chapter Five) which provided integrated services of management, commodity marketing, shipping arrangements, insurance of cargo and financing: Prior to independence of the Malay Federation in 1957, in 1953, 700 European-owned estates in the Malay Peninsular were managed by 20 managing agencies, of which 11 were merchant houses (Puthucheary, 1960). In addition, about 25 persons, some of whom were directors of merchant houses, sat on the boards of directors of nearly 200 rubber companies which owned nearly a million acres of rubber plantation. As for tin mining, in 1954 three managing agencies had vast authority over tin production. These were Anglo-Oriental (40), Neill and Bell (14) and Osborne and Chappel (10) which managed 64 of the 108 dredges in the Malay Peninsular on behalf of a total of 47 companies that accounted for 73 percent of total European-owned mining output (Jomo, 1986, p. 173). Also prior to the nation's independence, in 1955, 60 percent of the peninsula's imports and between 65 percent and 75 percent of its exports were in the hands of these British trading firms (Puthucheary, 1960, p. 75). Later, at the time of independence in 1957, the estates managed by the agency houses occupied about 65 percent of the entire cultivated area of Malay Peninsular. Also several years after 
independence, in 1965, three mining agencies, Anglo-Oriental (11), Osborne and Chappel (10) and Associated Mines (4) controlled the operations of 25 of the 43 public-limited tin-mining companies (Sumitro, 1968/69, p. 171). Some of these mining agencies were subsidiaries of the British-based holding companies. All this continued to be the case until the early 1970s: about 60 percent of the share capital of limited companies was owned by the British; in agriculture and fisheries, it was as high as 75 percent; in mining and quarrying about 72 percent; and in commerce and manufacturing, it was 63 percent and 59 percent of total share, respectively (Tun Hussein Onn Speech, 20 Feb. 1974, as found in Pillai, 1984).

Besides letting the foreigners to continue to be in control of the nation's economy, in its efforts to diversify the nation's economy which for so long had been dependent upon the rubber and tin productions, the post-colonial state was interested in attracting investments from overseas (Vreeland et al., 1976, p. 299; Linderberg, 1973). Thus, in its pursuance of an aggressive strategy of diversified industrial development, the Pioneer Industries Ordinance was passed in 1958 to provide various incentives to manufacturing firms. The government also established the Malayan (now Malaysian) Industrial Development Finance (MIDF) in 1960 and the Malaysian Industrial Development Authority (MIDA) in 1965 to stimulate large-scale industrial developments. Industrial estates provided with roads, water and power to encourage both heavy and light industries were also laid out beginning 1966. Not surprisingly, in 1959, when the top 156 companies accounted for more than half of all sales and employed about a third of the sector's labour force, foreigners - those with residences overseas - owned half the share capital in the top 83 companies (Wheelwright, 1965). Nearly a decade later, in a study using 1968 data, it is found that 77.1 percent of shares in pioneer firms were held by foreigners (Lindenberg, 1973). This percentage was greater than the 59.6 percent foreign share in manufacturing as a whole in 1970 (Mid-Term Review of the Second Malaysia Plan, 1973, p. 83, Table 4.7). The manufacturing sector developed rapidly and in fact became the most rapidly growing sector of the economy (Vreeland et al., 1976, p. 331). It was in such an economic environment where foreign investments were crucial that the accountants in turn were needed to play out variety of functions and which led to the need of the existence of an accounting body such as the MIA. But the MIA alone was not sufficient. So, it was not surprising that right after the nation gained its independence from the British, the then government had actually embarked in a pragmatic manner on a number of other steps to ensure the continuing active involvement of foreigners in the nation's economy then.

Among these was to have the Companies Act 1965 passed by Parliament and became effective on 15 April, 1966. The Malaysian Act which demanded companies to disclose more than ever before drew mainly on two sources (Walton, 1986): the Victoria Companies Act of 1961 and the British Companies Act of 1948. ${ }^{\text {xvii }}$ The former in turn was based upon UK Companies Act 1908, 1929 and 1948 while the latter on UK Companies Act 1929. The Companies Act 1965 was promulgated to bring together company legislations which prevailed in the component states in 1963 when Malaysia was formed. ${ }^{\text {viii }}$ The Parliamentary Debates (Vol II, no. 8, 9 Aug. 1965, Col. 1564) shows specifically that the Companies Act 1965 had two objectives: to protect investors and to attract foreign investors into the 
country. The Companies Act fitted with the nation's business environment then where the shareholders of companies and their creditors were largely foreigners. The government was interested in diversifying the economy, and the Companies Act appears to have been used as a "carrot" to attract foreigners to invest in the manufacturing sector. Thus, the pragmatic government in the 1960s went to considerable lengths to attract the foreign investors.

Besides the passing of the Companies Act 1965, the then government had embarked on a number of steps to ensure that the new nation would get its adequate supply of local accountants/auditors,. The then finance minister noted (CERPASS, June 1966, p. 1): "As a Minister of Finance, I would like to see within the next few years a rapid increase in the number of qualified accountants in Malaysia, accountants who will be second to none in their expertise .... In the rapidly expanding economy of Malaysia accountants will be a vital necessity and their services will be in ever growing demand." Thus, the Rural and Industrial Development Authority (RIDA) established by the government in 1958 had organised very early on the Training Centre for rural youth in stenography and bookkeeping. This RIDA Training Centre (which was in 1965 renamed as the MARA College of Business and Professional Studies and in 1967 as the Institut Teknologi MARA) in 1960 established the School of Accountancy offering courses in bookkeeping as single unit subjects. This school in 1965 offered the Diploma in Accountancy (DIA) for students who had completed the Cambridge Overseas School Certificate. This DIA programme was the "first" formal accounting study to be started in the country (Gul, 1983, p. 16). Also, the University of Malaya, then the only university in the country, had already sixteen students graduated with a Bachelor of Economics with Accounting specialisation in 1969 - after first introducing courses in accounting in the Department of Economics in 1961 (The Accounting Journal, 1970/71, p. 8). In each of its first three years of existence, the Accounting Division of the Faculty of Economics and Administration had well over 100 students.

The efforts by the government to ensure the existence of an adequate supply of accountants was matched by that of the private sector with the setting up of MACPA in 1958. The establishment of the MACPA and in particular its ICAEW-like examination and training scheme appeared to fit well with the then investment environment, with the British pretty much in control. The professional training and examination programmes that the MACPA embarked upon right after its formation appeared warranted now that the country had gained independence and accordingly was no longer in the position to accept non-citizens, i.e. the British accountants, to be practising as auditors in the country. As mentioned by Parker (1989, p. 18), the existence of a self-regulating local professional accounting body had developed rapidly only after the achievement of independence because "[u]nder colonial rule development was sometimes slowed down by, for example, restricting public company audits to members of British bodies." In Malaysia, it appeared that the concerned professional accounting body had indeed developed to some extent - but this was in British image in more than one sense.

The formation of the MIA by the government and the MACPA by the private sector gave evidence that the concerned parties had found that accountants had important roles to play in the nation's economy. In particular, their presence together with that of a number of 
other factors should be able to maintain the active involvement of foreign interest in the nation's economy. Unfortunately, on the part of the government, it was not that long after the MIA was formed when it appeared to have a change of mind on this very subject. Proof of that may be found in the fact that the MIA was laying low in the 1970s. To some extent race and government acting in a strong pragmatic manner seem to have brought such calamity to the MIA. The MIA had appeared to only wake up from its long slumber later in 1987 when it first conducted its first AGM. It was however a different case altogether in regard to the MACPA. It thrived - unfortunately in a manner that had brought much uneasiness on the part of many concerned parties in the country then.

The MIA Lying Low. For much of its first two decades of existence, the MIA had remained inactive. In a set of untitled bounded documents found in the MIA library, stamped on its first page as "Confidential" and dated 1 October, 1988 and which appears to have been forwarded to the then finance minister by the MIA council to gain his approval for the various amendments suggested for the Accountants Act 1967 (from hereon it will be referred to as the "MIA 1988 Bounded Document"), it was stated (p. 4) that from its formation in 1967, the MIA was acting as a mere registration body managed by the audit firm Price Waterhouse until 1981 and later after 1982 by the MACPA. The registering role of the MIA in those two decades was also well articulated by the MIA president, Haji Hanifah Noordin, just before the first MIA's AGM in 1987 (Business Times, 10 Sept. 1987). He said that “.... the earlier members of the [MIA] council not be entirely blamed for the inactive state of the MIA because in the earlier years it was felt that it should only be involved in its limited role of registering accountants in the country." xix From both the documented sources and interviews, a variety of answers can be suggested as to why the MIA was largely inactive for two decades. The matter of race and the fact that the government was acting in a pragmatic manner entered the picture in the answers provided by some interviewees. Documents inspected have however failed to support these reasons. The official documented view why the MIA was laid dormant not long after its formation may be found in the MIA 1967-1987 Annual Report (pp. 9-10). It says that the body

... has confined itself to playing the regulatory role to complement the functions of the MACPA, which has, since its incorporation in 1958, been actively involved in promulgating and developing standards of accounting practice, training of students and conduct of professional accountancy examination. It was the intention of the Council then not to undertake a parallel line of activities as that of the MACPA to avoid duplication of efforts and resources and confusion as to which set of standards that members of the profession should follow.

This explanation does not seem logical however simply because not all members of the MACPA are members of the MIA. The MIA "is" the national body and all qualified 
accountants were to be its members. In contrast, the MACPA only caters to a section of this accountant population known as the CPAs. Thus, the efforts and resources of the MACPA were dispensed for the benefits of their members to the exclusion of those who were not their members but were however members of the MIA. If the official reasons of avoiding duplication of activities and confusion were accepted, it appears however that still another type of confusion arose. This is portrayed in the following quotation derived from a paper presented in a seminar by none other than the then MACPA president, Dr. Nawawi Mat Awin, more than ten years after the MIA was formed (Nawawi Mat Awin, 1979, p. 10):

... in Canada there is no public confusion as to who accountants are. In Malaysia, we cannot be sure when press reports speak of an "accountant", whether he is a member of the MACPA or of the MIA, or of some other body or even if he is qualified at all. But the usual thing is to point a finger at the MACPA whenever there are any reports of alleged wrongdoing by an accountant .... there have been well-publicised cases where the "dramatist personae" are not our members at all but public presumption is that they are. Our writ does not extend to them and yet our reputation is affected in the public mind.

This very confusion was also mentioned in the same seminar by the then MACPA vice president, Megat Abdul Rahman. He pointed out that in the country there was a case of a divided accounting profession creating confusion in the public mind. He said (Megat Abdul Rahman, 1979, p. 9): "To delineate as to who is associated with which accounting group or body is an amazing task, for, a large number of members in MACPA are also members of MIA. There are accountants registered with MIA who are not members of MACPA." The "official" view that the MIA was not active in order to avoid confusion and duplication of efforts was also noted by the MIA president himself in the MIA's Berita MIA (Jan. 88, p. 1). But later in the run up to the MIA's council seats election in 1993 where both the MACPA and CACA (who since the MIA's activation in 1987 were in control of the MIA council) competed intensely, an MIA council member said that the MACPA's main aim in winning the seats was to re-assert its former controlling position in the MIA (The Star, 8 Dec. 1993). He was also quoted to say the following: "The MACPA was controlling the MIA council from 1967 to 1987 until Datuk Hanifah Noordin [the MIA president] and a group (of us) managed to activate the council in 1987 and gave it independence." It is notable that this very point which had been made a year earlier by an New Straits Times (NST) journalist, Shaik Osman Majid, in his column (NST, 3 Feb. 1992) has also found support in the interviews conducted. Specifically, the big six (then big eight) audit firms wanted to monopolise the audit market in the country. An active MIA with its own examination and members bigger in number compared to the MACPA (which was and still is in the hands of the big audit firms) could ultimately mean that there would be more competition for these big audit firms. So, these firms were alleged to have acted to ensure that the MIA would end up acting as a mere registering body for two decades. Thus, the blame for the MIA to be dormant for two decades could then be squarely placed at the door of the leaders of the MACPA who came 
from the big audit firms. Nonetheless, the interviews had also found that other parties including the person of the Accountant General and the government might also be considered culpable for what happened to the MIA.

Unofficial Views for Laying Low. In regard to the person of the Accountant General, a number of interviewees mentioned that he who was the president of the MIA then had strongly believed that the MIA was supposed to be acting as merely a registration body for accountants. A few interviewees associated with the MACPA also claimed that to be a registration body was all that the MIA was expected to be under the law. A top partner of a big six firm who also held a significant post in the MACPA mentioned:

The MIA is established not to be a full-fledged accounting body. The original intention of the people promulgating the Accountants Act 1967 was to have the MIA to be merely a registration body with the MACPA, the association representing qualified accountants. So what we are going to have in the MIA-MACPA relationship is meant to be like in the case of engineers and medical doctors in this country [where] their respective associations were matched in the government side by their registering bodies which are called Institute of Engineers and Malaysian Medical Council.

But when he was told during the interview that the Accountants Act 1967 appeared to have drafted the MIA to be a full-fledged accounting body, he agreed without further ado that that was indeed true. It was another matter however with an interviewee who was a prominent member of the business community and who previously had held a significant post in both the civil service and the MACPA. When he was told that it just could not be possible that the MIA was supposed to be a mere registering body due to the fact that the Accountants Act 1967 included mention of the MIA conducting an examination, he claimed that that examination was merely to enable the MIA to grant accounting professional qualification to the local accounting graduates, allowing them the opportunity to register with the MIA. He was adamant that the MIA was never considered by the authorities to have a role as a full-fledged accounting body. Nonetheless, the view that MIA was expected to act as a full professional body is supported by none other than his colleague in the MACPA. Subimal Sen Gupta, a council member of the MACPA who later became the MACPA president in 1982 mentioned (Report on the 3rd Asean Federation Accountants Conference, 8-11 September, 1982, p. 119):

... the Malaysian Association of Certified Public Accountants which incidentally is one of two accounting bodies in the country, the other being the Malaysian Institute of Accountants. The MACPA is the professional body which, as you may be aware, is also a body that sets its own examination which students have to pass before they can be admitted to membership. 
Also, since 1975, members of recognised overseas professional bodies, before they are admitted to membership, have to sit for and pass two papers in the MACPA exams covering local company law and local taxation. The Malaysian Institute of Accountants was set up by a statute and was given functions very similar to that of the MACPA including that of the registered body in the country. (Emphasis added.)

This quotation, from a leader of the MACPA itself, indicates there was no doubt that the MIA was no different to the MACPA in regard to the functions that it might play. Also, it appears that those people who argued otherwide had conveniently forgotten that the Accountants Act 1967 as mentioned above was based on Singapore Society of Accountants Ordinance of 1963 that in turn was based on similar Act implemented in New Zealand years earlier. Both the Singapore Ordinance and the New Zealand Act resulted in the emergence of full-fledged accounting professional bodies with both the power to regulate and promote the profession. Thus, this very view that the MIA had a limited role in the nation's accounting arena may be considered quite a weak one as to why the MIA laid dormant.

Another reason forwarded by a number of interviewees as to why the MIA laid dormant concerned the government which acted in a strong pragmatic manner and which was racial in conduct. They claimed that the government saw the need for the accounting graduates of the University of Malaya and MARA Institute of Technology to be recognised as qualified accountants. In other words, as a result of the MACPA's reluctance to recognise fully local accounting programmes, the MIA was established to ensure that there was a body to provide full recognition allowing the graduates to hold the post of accountants in the government service. With the recognition given soon after the MIA was established there was no reason to have the MIA to be active. ${ }^{\mathrm{xx}}$ Therefore, the MIA and the Accountants Act 1967 were merely "charades" in getting University graduates to be recognised as qualified accountants. One of the leaders of the MACPA also mentioned that the government after forming the MIA and ensuring that the MIA had given recognition to the accounting graduates of MARA and Universiti Malaya was unconcerned to have the MIA active for twenty years because the "percentage of Malay accountants then were quite small." Thus, there was also a racial basis for the MIA to be left dormant.

To be more exact, the MIA was left dormant due to the government's reluctance to see an organisation dominated by those who were not Bumiputra (who as a matter of fact formed the highest number of local accountants then as it is now) who would only create problems for the government. In other words, the government tried to avoid the presence of an active MIA that might be turned into a troubling Chinese-based organisation by its members the majority of whom were already Chinese Malaysians. With the background of the racial riots just a few years earlier, the government in the 1970s was not prepared to risk such an occurrence. Note that with the activation of the MIA in 1987, it appears that there are indeed a few signs that the Chinese-controlled MIA have created problems for the Malay-controlled government. $^{\mathrm{xxi}}$ In the case of the MACPA, though a clear majority of the members was non-Bumiputras, at the council level the Bumiputras held a majority of the seats. It was also 
claimed by an interviewee that personalities from the Malay dominated government sector had found it easy to deal with them rather than with what would possibly be an MIA dominated by the non-Bumiputra - this he said was proven in the late 1980s and the 1990s in what seemed to be a strong relationship between the government sector and the MACPA leaders but a weak one between the former and the Chinese dominated MIA council. Related to this point of a racial basis to explain why the MIA was left dormant for two decades, an interviewee who appeared to be very well informed about what went on over the years mentioned that there was no need in the 1970s and later in the second half of the 1980s - when the NEP was being implemented - for a strong accounting profession when the Malays in the country were "nowhere" in economic terms. This to him appeared to be the government's stance in "neglecting" the profession then. To him there was no need to follow other countries' manner of developing the accounting profession when the Malays were still poor and miserable. It was only after the economic condition of the Malays had improved that things like a strong accounting profession would be considered appropriate for the nation. Until then he said who would care what really was happening to the accounting profession? Certainly not in the case of the mostly impoverished Malays and thus the same for their representatives in the government. This very view signifies that if there really were a party who had to shoulder the blame for the MIA being left inactive for two decades, it was neither the leaders of the MACPA nor the person of the then Accountant-General. Instead, it was the government, itself, which did not seem to care about the importance of such a body and, as stressed by a few other interviewees, was pursuing a different "priority" at that time. Nevertheless, it is interesting to note the following from the former finance minister Tun Daim Zainuddin written replies to the list of questions sent to him:

The inactivity of MIA from 1967 (Incorporation year) until 1987 was not because of the lack of support from the Malaysian Government. Rather, it has much to do with the willingness of the accountants in Malaysia to agree to forge together into a single professional body capable of representing the interests of their profession in Malaysia. To this extent, their views and stand would be more appropriate other than authoritative position.

Still another reason why the MIA had failed to be active was uttered by two interviewees. This reason may be related to the environmental factor of a government acting in a pragmatic manner. These interviewees claimed that the aims of the then government in having the MIA established were to produce accountants in a manner different to the articleship as implemented by the MACPA and to have more Bumiputra recognised as qualified accountants. Also, the MIA was to be a body to look after the interest of accountants in the fast developing commercial and industrial sectors which appeared to have been neglected by the MACPA which focused on public accountants. Then "for whatever reason" they claimed that the MACPA leaders felt that it could also encompass these roles plus numerous others, leaving the MIA as a mere registering body while the MACPA which "was controlled by the (then) big eight" was more and more behaving like a national accounting body. Thus, for 
example, in 1975 the MACPA introduced the Development Scheme with the Stream II and Stream III. The former concentrated on articleship in industries, commerce or government offices. As for Stream III where in July 1978 the MARA Institute of Technology whose students were all Malays was chosen by the MACPA as the first institution in producing CPAs through formal study, the MACPA had shown that it was now getting serious in producing more Bumiputra accountants too. Thus at the end, as claimed by these interviewees, there appeared to be no good reasons left for the government to want the MIA to be active. ${ }^{\text {xii }}$

The final view as to why the MIA laid dormant for around two decades was probably the weakest one. Numerous interviewees had mentioned that the MIA had failed to be active because the MIA then did not have the "people" to become active. Related to this view was the suggestion that the MIA members then were quite satisfied with the work done by the MACPA $^{\text {xxiii }}$ or were mainly interested in making money and not in ensuring that the MIA fulfilled its functions. Added to these was the fact that the local accountants viewed associating with foreign-based accounting bodies as of higher-status compared to being associated with a local body the MIA. ${ }^{\text {xiv }}$ Thus, there was no interest to see the local body became active. Instead these people would make sure that local branches of the foreign bodies played an active role to support and regulate activities of the members. These views can be questioned however because it was found from several other interviewees that from the 1970 s to the early 1980s, numerous people had in fact tried very hard to get the MIA to be active. A former leader of the Malaysian Chapter of the CACA, ${ }^{\mathrm{xxv}}$ who together with the MIA president were appointed by the then minister of finance in the mid-1980s to sit in the MIA council prior to its activation in 1987, mentioned that in the 1970s and the early 1980s, he wrote a lot of letters to the MIA and "everybody" including the Accountant-General to ask "Why the MIA was dormant?" He also sent out one petition after another but nobody bothered to even respond. He said that he and his friends did everything possible except bringing the people concerned to court! ${ }^{\mathrm{xxv}} \quad$ In his opinion and a few others interviewed, the MIA was inactive for two decades not because the members were not trying hard enough. It was because the authorities did not care to see the MIA to be active. The MIA vice-president interviewed also mentioned that around the middle of 1980s, he and a few other parties were lobbying quite heavily for the MIA to be activated, particularly because they saw that a few MIA council members who died in office did not have others to take over the council seats that they left behind. Also, another member of the MIA council mentioned that the MIA members in the 1970s and early 1980s had filed requisitions to MIA's registrar Tan Sri Dato' Jaafar Hussein - for the MIA to organise an AGM. But the Tan Sri did not bother to act. He said that the accountants from the southern state of Johor where he came from were very vocal in this matter.

There are indeed more than a few reasons for the MIA to have been lying low during the 1970s and later until the late 1980s. But regardless of the actual reasons for the MIA lying low, the consequences were real and had been reasonably documented. These included the proliferation of unqualified (bogus) accountants, the shortage of qualified accountants and disciplinary chaos (see Azham Md. Ali, 2001). The fact that the MIA was 
left dormant for two decades had also provided the MACPA with the chance to thrive. After the MACPA's secretariat had moved from Singapore to Kuala Lumpur in March 1970, the following years saw the association playing the role of an active accounting body worthy to be in competition with that of the statutory accounting body MIA. It even went to the extent of conducting a series of talks with the MIA to "merge" the two bodies. The MIA 1967-87 Annual Report (p. 14) noted that it was on 7 December, 1972 that the MIA council had begun to hold discussion with the MACPA council on "the amalgamation of the two bodies to represent the accountancy profession in Malaysia." "xxvii And the MACPA Annual Reports for the years 1981 (p. 20), 1982 (p. 21), 1983 (p. 23) and 1984 (p. 22) disclosed the various efforts taken by the MACPA to ensure that the "merger" would eventually take place. It is notable that the MACPA was involved in several other areas too. The MACPA official journal, The Malaysian Accountant (July-Sept. 1988, pp. 10-11), revealed the various activities of the MACPA during the 1970s and 1980s.

The Thriving (But Insufferable) MACPA. Among the activities conducted by the MACPA while the MIA laid dormant included those which may be categorised into two fields: professional training and examinations and accounting/auditing standard settings. In both areas, MACPA had successfully alineated itself from many parties in the country. The government did not seem however to show any interest - perhaps it understood that the presence of a thriving MACPA regardless of what it entailed was necessary to cater to the interests of foreign investors. In this regard, the government may be said to have acted in a pragmatic manner.

Professional Training and Examinations. It was one of the leaders of the MACPA itself, Megat Abdul Rahman, who claimed (Megat Abdul Rahman, 1980, p. 2): "The role played by foreign-trained accountants in the development of the accountancy profession in Malaysia cannot be overstressed."xxviii Nonetheless, in January 1976, the MACPA had enforced a new membership admission ruling requiring foreign trained accountants to sit the qualifying exam, comprising two papers on Malaysian Taxation and Company Law, before they could become members of the MACPA. ${ }^{\text {xix }}$ Thus, it turned people away from the association, and the MACPA with this very act had also been accused of being elitist and acting like a closed shop. An interviewee who himself could be considered a leader of the MACPA said: "The people are not given any attention by the MACPA. Instead, the MACPA is more like a closed shop. They want to protect their interest and therefore they make their standards more stringently." Also as noted Yap Leng Kuen in The Star (23 Aug. 1988) in referring to the foreign-trained accountants: "Since 1975, it had been difficult for these accountants to get into MACPA, because they had to sit for two papers - company law and taxation. They are now unhappy that MACPA seems to be holding onto its forte which some of them have branded to be 'elitist' in nature." Besides enforcing the new membership admission ruling, from 1976 onward, the MACPA enforced new minimum entry standards for students registration with the MACPA. If earlier it was the Malaysian Certificate of Education (MCE) with five credits, 
including English and Mathematics, now it was at least two passes at Principal level in the Higher School Certificate (HSC) plus credits in English and Mathematics and a pass in Malay Language at the MCE level (Megat Abdul Rahman, 1980, p. 2). Also, from August 1975, the MACPA began a system of practising certificates. That is, its members who would like to practice public accounting now needed to attain the relevant public accounting experience for between one to two years under the supervision of MACPA practising members before they could get an MACPA practising certificate. Megat Abdul Rahman (1980, p. 6) wrote that the period of approved experience varied from 12 months for members qualifying under Stream I to 24 months for those qualifying under Streams II and III and for those admitted by virtue of being members of foreign bodies.

With all these actions of the MACPA beginning from the last half of 1970s, it was not surprising that the country was beset with the problem of shortage of accountants. The then vice-chancellor of the University of Malaya had noted (The Accounting Journal, 1977, p. iii) (Translated): "Our country needed very much a big number of accounting graduates who are professionally qualified. The shortage is clear not just in the private sector but also in the public sector." Also, the Committee on International Accounting Operations and Education (1976-768) of the American Accounting Association (AAA) (1978) issued a report entitled "Accounting Education and the Third World" where the issue of shortage of accountants was discussed. Prof. C.L. Mitchell who was assigned by the committee to conduct the assessment on Malaysia wrote that the country was having a great demand for accountants compared to that for doctors to the point that the former earned higher incomes compared to the latter. Later in 1981, the then Auditor-General, Tan Sri Dato' Ahmad Noordin Zakaria, mentioned that the shortage of financial personnel in government had affected the smooth running of its activities (Ahmad Noordin Zakaria, 1981, p. 25). He also disclosed that an additional of 1,971 accountants were needed for the duration of the Third Malaysian Plan, 1976-1980. Gul (1983, p. 13) had clearly placed the blame on the MACPA for what was happening. He said that the MACPA efforts in the training of accountants were not appropriate for a fast developing country that needed an increasing number of accountants in both the private and public sectors. He also noted that for the Third Malaysian Plan (1976-1980) an increase of 111 percent on accountants was needed compared to that of doctors 38 percent, and lawyers 35 percent. Gul (p. 20) next claimed that the responsibility of educating accountant for the country's need has fallen on the shoulders of the universities and colleges. But even in this case the MACPA was not being much supportive. In fact, it may be argued that its efforts to restrict the entry of potential accountants into the field (bringing much benefits to its few members) is also reflected in its reluctance to provide full exemption from exams to students graduating from local universities with degrees in accounting. The MACPA required these students to sit on some papers before they could ever hope to become CPAs.

The act of giving limited recognition to local accounting graduates ensured that not many of them were able to turn out as CPAs after studying at the universities (Megat Abdul Rahman, 1979, p. 4). Again, Gul (1983, pp. 21-30) who disagreed with the MACPA policy on giving limited recognition to local accounting graduates explained that based upon his 
analysis of the accounting degree programmes offered by the University of Malaya, Universiti Kebangsaan Malaysia and Institut Teknologi MARA (ITM), they had more than adequate coverage for complete MACPA recognition. He (p. 49) expressed his disagreement with the MACPA by saying that while the MIA provided full recognition of the accountancy course in various institutions the MACPA had been "tardy". Indeed, the MACPA's limited recognition of the local accounting graduates was much regretted from very early on by the authorities. See the Editorial to The Accounting Journal (1971/72, p. 7 ) and the remark made in another issue of the journal (1977, p. v). Also Prof. Beedle from Canada in his speech on 27 October, 1974 pointed out that the MACPA's reluctance to give total exemption to the University of Malaya graduates was not what was expected and hoped for by the authorities such as the former ministers of education and finance (The Accounting Journal, 1974/75). ${ }^{\mathrm{xxx}}$ He also said: "The MACPA has said, (perhaps with some reluctance - maybe with trepidation, rather like the virgin spinster who fears rape by the over-eager suitor, but certainly not with the ardent response of the young lover) - "Yes, we will grant the University some additional privileges - some additional recognition - but do not expect us to indulge in an all-embracing betrothal - a fulsome consummation of marriage."”

When a long time council member of the MACPA was questioned in the interview as to why the MACPA was reluctant to recognise fully local accounting graduates as qualified accountants, he mentioned what was also pointed out by another two of the MACPA leaders interviewed. That is, the MACPA could not put aside its requirements for articleship, exams, etc. because the body believed strongly that accounting/auditing was not so much a knowledge-based activity but rather a skill-based one. The CPA tag could only be attached to names of those who were experts in the accounting/auditing field. In short to gain that tag it was not through being educated in universities but through doing practical things in accounting firms. He also mentioned that the MACPA was firm in its belief NOT to provide automatic recognition to accounting graduates for the very act of giving automatic recognition would be a "dilution of the standard of the profession", which in turn could bring down the quality of auditing. He claimed that if the MACPA was to grant recognition indiscriminately it would increase the cost of auditing, which could ultimately bring adverse consequences for the nation's economy. He denied that the MACPA was trying to be an elite body.

By not giving full recognition to the local accounting graduates who are largely Bumiputra has also ensured that very few among the CPAs in the country are Bumiputra. This was readily disclosed by an MACPA council member. Roughly a year before the NEP came to an end, he disclosed that Bumiputra accountants made up only 7.5 percent of the MACPA members while only 14 percent of its registered students were Bumiputra as of 31 July 1989 (Business Times, 5 Aug. 1989). Chinese and Indian accountants represented 83.3 percent and 5.9 percent of MACPA members respectively, while its students were 79.5 percent Chinese and 4.9 percent Indian. It means thus that the effort of the government under the NEP to restructure the society whereby among others 30 percent of each established professional groups should be comprised of Bumiputra is not supported by the MACPA - the only local accounting professional body with its examination and training 
programmes available for the local population to join. The conduct of the MACPA in not expanding the number of Bumiputra accountants did not seem to have attracted any open criticism in the 1970s. It was however a different story altogether in the late 1980s after the MIA was revived in 1987 and the altercation between the leaders of the MIA and MACPA was reported widely by the written media. In 1988, the newspaper Utusan Malaysia (21 July and 1 Aug.) published two letters which mentioned several issues including the failure of the MACPA to expand the number of Bumiputra accountants. The letter published on 1 August, 1988 mentioned first of all that the recent MACPA celebration of its 30th Anniversary with the leaders of the body remarking on their pride in the achievement of MACPA to date was without foundation. Mockingly, the writer asked how many Bumiputra accountants the MACPA had been able to produce. He or she next said scathingly that half of the MACPA council were Bumiputra who did not bother to implement government policies and national identity. He or she pointed out that they did not take the advantage of their position to do what was right and at the same time they did not realise that they were in fact being used by the non-Malays in the organisation. ${ }^{\text {xxi }}$

From interviews conducted with several leaders of the MACPA, a typical view was as the following: "The MACPA should not be blamed for failing to increase the number of Bumiputra accountants. The MACPA could not do much really because the Bumiputra entrants are of "low quality" compared to the Chinese entrants. As a consequence, these Bumiputra students are unable to pass the exams even after several attempts!" One of these interviewees had also said: "It is difficult for the MACPA to increase the number of accountants when there are so many Malays compared to the Chinese who do not fulfil the minimum requirements needed to enter the profession in the first place. And for those Malays who are able to sit for the exams, the majority failed miserably. What could the MACPA do in such cases?" He and the others also pointed out that all the brightest Malay students had already left the country to study overseas leaving these "low quality" ones behind! So they claimed what choice had the MACPA got other than to fail those who did not deserve to pass the exams based upon the quality of their answers?

Accounting/Auditing Standard Settings. In 1974, a study sponsored by the KLSE concluded that the participants of the market comprised those who placed little reliance upon financial statement data, which explained the minimal financial disclosure practised by the listed companies (Mitchell, 1974, p. 1). Some blame for this situation was placed on the MACPA which was seen as the country's "auditor's association" (p. 6). Mitchell wrote that some "observers" considered that the auditor's association held a biased and restricted view of disclosure problems. Thus, in referring to the MACPA's Statement No. 1 issued in June 1972, he mentioned (p. 6) that it "... represents the initial step of the long march of progress." Within the few years after Statement No. 1, the MACPA issued three more statements. All these statements said Megat Abdul Rahman (1980, p. 4) were based on ICAEW statements. In October 1975, the MACPA was admitted as a member of the International Accounting Standard Committee (IASC). ${ }^{\text {xxii }}$ Following membership of the IASC, the MACPA by the late 1970s embarked on the introduction of the International Accounting Standards (IAS). 
The IAS 1 to 4 were adopted at the beginning of 1978 (The Malaysian Accountant, July 1986, p. 11). Nevertheless, it appears that there were many problems in the early years of the implementation of the IAS. Some of these problems were the results of the MACPA's haste in their introduction and its lack of any guidelines in applying the rules (Cooper, 1980, p. 1). The MACPA crammed into 3 years what many countries had spread over six years in applying the first ten IAS. It was also claimed that companies were not comfortable providing greater disclosures. As a result, there was a lot of non-compliance by companies and a great diversity of accounting practices between industries and between companies in the same industry in these early years for both listed and unlisted companies (Cooper, 1980; Megat Abdul Rahman, 1980, p. 5).

The Editorial to The Malaysian Accountant (1980, pp. 45-46) mentioned that small audit firms were having difficulty getting their clients who were small businesses, and particularly the family-owned businesses, to comply with the IAS. The owners/managers of these businesses believed that to have their accounts prepared in accordance with the Companies Act was sufficient. The Editorial further stated that, as nearly 99 percent of the 50,000 small businesses then employed book-keepers who were ignorant of IAS instead of qualified accountants, there was little expectation that the IAS issued by the MACPA were in fact being implemented. Finally, the Editorial laid out various practices inconsistent with IAS 1 to 8 (pp. 46-49). When reference is made to the MACPA Annual Reports for the years 1982 (p. 20), 1983 (p. 22), 1984 (p. 21), it is clear that the MACPA president then who was Megat Abdul Rahman was having difficulty in promoting IAS compliance from MACPA members. So it is not surprising too to find that in 1982, Subimal Sen Gupta, an MACPA council member who later became its president, mentioned that some of the standards adopted by the MACPA had met with a "sea of opposition" not just from businesses, company finance directors and accountants, but also from a lot of auditors themselves who felt that the MACPA was going too far (Report on the 3rd ASEAN Federation Accountants Conference, 8-11 September, 1982, p. 122). He claimed that the view of these parties was that certain requirements were sensitive for disclosures like turnover, inter-company transactions and so on. He further stated that the coming merger between the MACPA and MIA would create a "new body" and any standards set by the new body would have the backing of statue. Standards would have "more authority" leading towards "very, very few non-compliance in the future". Five years later in 1987 when the merger had already failed to take place, Gupta, then the MACPA president claimed that now that the MIA had adopted all the IAS, companies no longer had the opportunity to choose between accountants and auditors who were expected to comply with the IAS and those who were not (The Malaysian Accountant, July 1987, p. 3). Next he said: "With this distinction removed, I, therefore, urge all accountants in this country, particularly the members of the MACPA to comply with all standards of the Association, both in technical and ethical fields ...."

With much problems faced by the MACPA in ensuring that concerned parties complied with the IAS, it was perhaps inevitable that the MACPA later in the 1980s had appeared to be slowing in its adoption of the accounting standards and auditing guidelines. Yong Hang Chang (1988, p. 138) mentioned in his PhD thesis that the MACPA at the time of 
his writing had adopted IAS 1-14, 16-18, 21 and 23 and rejected IAS 15. As for the IAS 19, 20, 22 and 24-26, they were still under consideration. With this revelation, it should not be a surprise to discover remarks made by Gul (1983) that inadequate accounting standards had contributed towards there being insufficient financial disclosures for the KLSE to function properly and accordingly to gain the confidence of potential investors. Gul also wrote (p. 38) that the lacking of disclosure appeared to have discouraged some investors from getting involved in the KLSE and thus provide the capital needed in an expanding economy. $\mathrm{He}$ claimed that the amount of information found in external reports for most companies was often of little use for investment decisions and that investors were uncertain about its reliability. Gul summarised the situation as follows (p. 47): "Accounting practice in the country in its present form is not conducive for the economic development of the country. The lack of reliable up-to-date accounting information both for external as well internal purposes is a serious impediment to our economic development efforts .... The present quality of Accounting Education, Research and Practice in Malaysia is relatively unsatisfactory."

Discussion. The fact that the MIA was dormant may be attributed to more than a few factors including ethnicity and the government acting in a strong pragmatic manner. But while the MIA remained largely uninfluential, the privately organised MACPA with its power limited to only a fraction of the total number of accountants in the country had conducted itself in whatever way it felt was right - with hardly any interference or much expectation from the government. And sadly what the MACPA felt right had in many cases turned out to be "wrong" for others. All in all, it appears that "anything goes" was the basic story behind the sorry state of accounting profession in the country during this period. Hence, the accounting arena during the 1970s and much of the 1980s did not appear to be what was envisaged in the 1960s when the MIA was formed. The only way perhaps to explain this is that the accounting establishment then was facing an environment totally different to that prior to the occurrence of the 1969 racial violence and the subsequent implementation of the NEP.

In a matter of days, following the release of the 1969 general election results where the Chinese-dominated opposition registered impressive gains at the polls, the Malays and the Chinese fought on the streets of Kuala Lumpur resulting in 196 people dead and hundreds more injured. The unofficial estimate of the total dead however was as high as six or seven hundreds. A lot of properties were also looted and burned down (see Bass, 1973; Parker, 1973; Stephen Hong-Chye Chee, 1971; Goh Cheng Teik, 1971; and, National Operations Council, 1969). Thus, what appeared to have worked before including the continued strong foreign ownership of the country's assets now appeared to say the very least, unhelpful, for holding the country together. In the political field, it took the constitutional amendment of 1971 to set forth new rules of political behaviour for the 1970s and beyond. And in the socio-economic field, the NEP was launched. The policy was incorporated within the First Outline Perspective Plan (OPP1)(1970-90) issued by the government in 1973. The goals of the NEP to be achieved by 1990 were to eradicate poverty - regardless of race and irrespective of geographical location - and to reduce imbalances in income, employment and ownership of assets among the various races in the country. ${ }^{\text {xxiii }}$ As a result, the role played 
by the government in the nation's economy became very important. The government was in short in direct participation in the nation's economy "on behalf" of the Malay people.

Numerous strategies were implemented (see Azham Md. Ali, 2001) Among the notable ones included the establishment of various trusts that used government funds to purchase foreign-owned shareholdings on behalf of the Bumiputra population. In the case of rubber and tin production, the traditional bedrock of the economy, where foreign investment and management had been dominant for several decades, it now gradually shifted to Malaysian or more specifically Bumiputra control (Kenzo Horii, 1991; Keiko Saruwatari, 1991). In fact, in a period of seven years after the launching of the NEP in 1971, the state had taken ownership and control of almost all the large plantations: Sime Darby, Guthries, Boustead, Highland and Lowlands, Barlow and Harrisons and Crossfield (Lim Mah Hui, 1988, p. 24). Also, in 1976, the government took control of the largest tin-production in the world. As for the financial institutions, by 1976 the state had a share of at least 40 percent in each of the three largest domestic banks: Bank Bumiputra, Malayan Banking and United Malayan Banking Corporation (Khor Kok Peng, 1983, p. 121). And by 1980, the state owned 77.4 percent of the local banking industry and 50 percent of the total banking industry (Lim Mah Hui, 1988, p. 24). Thus, the government had basically direct control over much institutional credit and this in turn signified its influence not just over its enterprises but also over the rest of the business community. The part played by the government as the nation's banker was quite crucial, considering the fact that the stock market was nothing of consequence to any party during this time - just like what it was before. It was more a place for gambling by the very rich. ${ }^{\text {xxiv }}$

It was in this kind of distinctive social-economic and political environments that accounting and accordingly the MIA were treated as if they were no more relevant by the authorities who now played the various roles of regulators, bankers, shareholders, managers, employers, etc. Nevertheless, since foreign investment was considered by the government as a crucial ingredient to the fulfilment of the NEP goals of poverty eradication and restructuring of society, the MACPA, controlled by the internationally affiliated audit firms whose clients would include these foreign investors, was left free to do what it felt necessary in developing the accounting profession. Thus, it may safely be said that the government in this regard was acting in a pragmatic manner.

From interviews, it was found that foreigners had certainly faced no problems in dealing with those from the MACPA. Thus, it seems that the support provided by foreigners, in particular those who came in to invest in the country, had ensured the continuing active existence of the MACPA during this time period. It is not difficult to infer the influence coming from these foreign investors. This is because while acting as the primary engine of growth of the economy, the government then did not forsake the need to continue attracting investors from overseas to develop the manufacturing sector. Thus, for example, free-trade zones (FTZs) were introduced in several states in 1974 to enable manufacturers to import free of duty machinery, raw materials and component parts and to export finished goods with a minimum of customs formalities (Rajah Rasiah, 1993). The industries located in the FTZs contributed to the expansion of manufactured exports as the share of manufactured products 
exported came to be 11 percent of total exports in 1973 compared to mere 3 percent in 1960 . As a whole, in the manufacturing sector, foreigners invested substantially in accord with the government's encouragement and the various incentives offered. The involvement of these investors in the manufacturing sector ensured that a large proportion of the corporate sector of the economy was in foreign hands - even after the restructuring of their corporate ownership following the dictate of the NEP.

At this stage, it may be concluded that the fact that the MIA was largely left idle in its first two decades of existence leaving the MACPA to thrive taxingly signified the authorities lack of concern with the need for the healthy functioning of the nation's accounting sector. Those in power certainly have quite "personal" reason (as opposed to those mentioned earlier) for neglecting the accounting profession: they did not want the presence of accounting practitioners represented by a strong and respected MIA to make their life unnecessarily difficult given the "underhand" acts that they committed (or had to commit) to ensure the goals of NEP (or "their own") were fulfilled at "whatever" price. This very point was made clear by the leader of Aliran, the NGO for "freedom, justice and solidarity" in Malaysia, Chandra Muzaffar (1989, p. 99) when he tried to explain the reluctance of national leaders to act on those responsible for corrupt activities. ${ }^{\mathrm{xxx}}$ He writes: "To expose their misdemeanours would be to expose the New Economic Policy's not so subtly concealed agenda of creating Malay capitalists, whatever the costs and the consequences. Ethics have to be set aside for the time being - so it has been argued in certain official circles - to facilitate the rapid growth of a Malay capitalist class." In this regard, the character of a government acting pragmatically may be traced once more with no difficulty.

However, the need for change in the treatment provided to the accounting profession had finally emerged not long after the federal cabinet headed by the Prime Minister Dr. Mahathir Mohamad rejected the proposal to "merge" the MIA and MACPA in 1985. This came in the form of the activation of the MIA in 1987. As a result, another era of accounting development in the country seemed to have emerged. The rejection of the proposed merger provided the picture of the impact of ethnicity and strong pragmatic government on the accounting arena, while that of the activation of the MIA signified the influence of not just ethnicity and strong pragmatic government, but also that of foreign investments.

The "Rejection" of the MIA-MACPA Merger Proposal. The proposal for the merger envisaged the amendment or if necessary, the repeal of the Accountants Act of 1967 and the liquidation of the MACPA and the incorporation of a new body under an Act of Parliament. This new body was to be named Malaysian Institute of Chartered Accountants (MICA) (Megat Abdul Rahman, 1979, pp. 14-20). On the surface, the rejection seemed surprising. After all, several documented sources had mentioned that it was in 1979, when he was still the Deputy Prime Minister holding the post of Acting Prime Minister, the Prime Minister Dr. Mahathir himself had mentioned that it did not make sense to have a multiplicity of bodies in the profession, particularly in a small nation like Malaysia (Abu Hassan Kendut, 1986, p. 12). Similar remarks attributed to him were also noted in the Editorial to The Malaysian 
Accountant (July 1981, p. 5). In a letter published in the same issue of The Malaysian Accountant (p. 4), the following was noted as what was exactly mentioned by him: "The Government wants to see the development of a Malaysian accountancy profession with the capacity to serve the increasing needs of the nation to the highest internationally comparable professional standards and to effectively regulate the activities of its members for the maintenance of such standards. A strong unified profession will be better able to achieve this and look after the interests of its members." When the rejection was made by the federal cabinet on 17 June 1985 (Business Times, 12 Oct. 1988), following was given as the reason: there was no need for MICA for there was already in the country an accounting body entrusted with all the needed task to spearhead the accounting profession in the form of the MIA (MIA 1967-1987 Annual Report, p. 11). Not surprisingly perhaps, those from the MACPA were not happy with this turn of event. In the year following the merger rejection, the then MACPA president mentioned (The Malaysian Accountant, Oct. 1986, p. 4): "The MACPA also regrets that the proposals for the merger with the MIA have not met with the approval of the cabinet. After several years working towards this objective, the Council of the MACPA is of the firm view that there is no alternative to a Single National Body of Accountants in Malaysia and seeks the support of the Ministry of Finance in achieving this objective." $x x x v i$

It is interesting to note however that from interviews it was found that there was no "outright" rejection by the government. A number of interviewees indicated that it was the accounting bodies themselves that did not want unification - in the form that the government would like. In other words, the federal cabinet was actually ready to accept the merger in a quid-pro-quo kind of arrangement. It was the accounting bodies' insistence that all matters follow their wishes that resulted in the so-called "merger" failing. As one of the interviewees had insisted: "It was not the government that rejected the merger, for it was the two bodies which did not want the merger to go through." So what happened was that the government would have agreed for the "merger" to take place if the new merged body MICA - would have in its schedule list of recognised accounting bodies a number of government sponsored accounting bodies and qualifications (where majority of the people involved happened to be Malays). The inclusion of these bodies and qualifications would ensure that those involved could be taken in as public accountants and in turn would have them permitted to audit companies. But as one leader of the MACPA put it: "To have these people to come in as full-fledged members is just unthinkable! Regardless of the fact that powerful government ministers are behind them." It could not be ascertained however from the various interviews how many accounting bodies and qualifications exactly were involved and what they were. A few interviewees recalled only one body: the Institute of Cooperative Auditors (ICA) sponsored by one of the government ministries. As for the accounting qualifications, several mentioned accounting degree programmes from local higher institutions. In other words, the MIA and MACPA was asked by the government to have the merged body MICA to provide automatic recognition to the accounting degree holders - after their three years of earning the relevant practical experience and with no need to sit for any professional examinations organised by the body. 
In regard to the ICA in particular, one of those interviewed had mentioned that its members came about through "political appointments". Four federal cabinet ministers were in fact involved in their appointments as auditors. Thus, both the MIA and the MACPA felt that it was "too high a price" to have the ICA included in the schedule of approved accounting bodies of the Accountants Act in order to get the merger approved. A number of interviewees also mentioned that the MIA and MACPA leaders were fearful that politicians through ICA and their other sponsored bodies would later interfere with the operations of the new merged body MICA - if it were formed. One interviewee however did not stress this "fearful" factor that resulted with no merger taking place. Instead, he mentioned that the leaders of the accounting bodies were trying to avoid the case of having too many public accountants around working as company auditors which could lead to stiff competition in the audit market! To recapitulate, many of the interviewees stressed that both the MIA and MACPA wanted very much for the merger to take place - but not at the "price" of expanding the list to include the ICA and other accounting bodies or qualifications whose people involved were majority Malays. As a result, the government was forced to reject the merger proposal. This revelation was made by a number of interviewees and may be considered a commonly held view. It is notable that during the same year when the federal cabinet rejected the "merger" proposal, the Associate of the Institute of Cooperative Auditor - ICA's professional qualification - was recognised by a government agency, the Public Service Department (PSD), as equivalent to the advance diploma in accountancy from MARA Institute of Technology. There is thus the very high probability that this particular account of the so called government's rejection of the merger proposal is more reasonable (though there appears to be no documented sources found to have said so directly) than that of the straightforward reason that there already existed in the form of the MIA a mechanism for the unification of the accounting profession.

Discussion. It may be safely said that the merger deal of 1985 did not go through for reasons which were racial in content: first, there was no agreement between the government and the leaders of both MIA and MACPA on the subject of giving recognition to at least one accounting body (whose members were majority Malays) in the supposedly new merged body; and second, these parties did not agree on the matter of turning local accounting graduates (majority Malays) to qualified accountants automatically. That the racial explanation may to a good extent account for the reason why MICA had failed to emerge may be more acceptable than any other explanations is further stressed by the very fact that the government's move to have the ICA and other bodies or qualifications included in the schedule list of the new merged body was not really to increase the number of external auditors - after all when the merger proposal was presented to the federal cabinet, the country was in the depth of the worst economic recession to that date (to be mentioned later) where many companies had to close down their businesses and the government thus was having problem in financing its many activities. Instead, it seemed the government made the counter proposal for it was desperate to raise the number of Malay qualified accountants in the fulfilment of the NEP which was about to come to an end in a few years time. That the 
government had such an aim may be deduced from the revelation made in the "MIA 1988 Bounded Document" (p. 6) of what took place around shortly before the MIA-MACPA merger had failed to take place: the government was "horrified" and "saddened" to discover that up to 1984, there were less than five percent of the total qualified accountants in the country who were Bumiputra. In other words, the number of Bumiputra accountants was unacceptable considering the fact that over half of the population were Bumiputra.

The fact that the government during the NEP era was taking a serious view of this matter may be found from other documented sources. In 1979, the then Prime Minister, in closing the Bumiputra Economic Congress, stated that Bumiputra comprised only 7.6 percent of all accountants (Megat Abdul Rahman, 1980, p. 3). A decade later, it was the then finance minister, Tun Daim Zainuddin, who mentioned that it was so sad to have a mere 9 percent Bumiputra who were members of the MIA (Akauntan Nasional, Aug. 1989, p. 25). And this percentage he noted was the lowest among all professions in the country, where in law, it was 18 percent, medicine 21 percent, engineering 23 percent and architecture 31 percent. During the same year, the Prime Minister in the Parliament disclosed that the inequilibrium between Bumiputra and non-Bumiputra within a selected number of professional groups was quite clear: it was a ratio of 1:3 (Berita Harian, 29 June 1989). He also said that among the various groups - architect, accountant, engineer, dentist, doctor, veterinarian doctor, lawyer and surveyor - the accountant had the lowest percentage of Bumiputra at 11.5 percent or 514 out of 4,466 total accountants. All in all, it may safely be concluded that in the mid-1980s, the government which was well aware of the problem of a small number of Bumiputra accountants had thus made a pragmatic move to increase that number by making the appropriate counter proposal to that from the MIA and MACPA. The merger would have taken place if only the two accounting bodies had agreed to the government proposal. And with the merger possibility no more in sight, it appears that the government had next directed the MIA to be activated so that it might play the role of the national accounting body as envisaged by the Accountants Act 1967 (Akauntan Nasional, July 1992, p. 5).

The Activation of the MIA. In September 1987, the MIA members had their first AGM. A number of Chinese Malaysians from the CACA (MC) were elected to sit in the MIA's fifteen-person council. The part played by the government in having the MIA activated is never disguised. In 1991, in the MIA booklet entitled "Who is an Accountant?" which was distributed to schools and institutions of higher learning, it is stated (p. 17) that "[t]he government, concerned about the state of the profession as well as the problem of unqualified accountants, directed that the MIA be activated so that it could play the role of the national accountancy as envisaged under the Accountants Act." The following year, the MIA president said (Akauntan Nasional, Aug. 1992, p. 25):

25 years ago our wise leaders enacted an Act of Parliament which give birth to the MIA dedicated to the ideal of unity for all accountants in the country. This ideal became an elusive dream through 20 years of dormancy of the MIA. 20 years after the birth of the 
MIA, our leaders reaffirmed their commitment to this ideal by waking MIA from its long slumber since its birth in 1967.

Therefore, it appears from these quoted remarks that the initiator for the activation of the MIA was the government - not the members of the MIA or any other parties as mentioned by a number of interviewees. This and the exact reasons for the MIA to be activated were revealed in the "MIA 1988 Bounded Document". The significance of the matter of ethnicity and that of foreign investors is clearly seen. First, it stated (pp. 5-6) that when the then federal cabinet rejected the MACPA proposal for the merger of the MACPA with the MIA, the MIA was "directed" by the government to be active. The document went on to state that the government did so because of the state of the then accounting profession reflected in various financial scandals which resulted with a loss of confidence in the profession among the general public and "foreign" businessmen. This document also stated that the government would like the MIA to be activated due to the proliferation of unqualified accountants who had caused the government to incur millions of ringgit of losses as a result of their falsification of their clients' accounts. It clearly said that the government was hoping that with the MIA activated, efforts would be directed towards increasing the number of Bumiputra accountants and the use of the Malay language in the accounting profession. And as mentioned above, it also pointed out that the government was "horrified" and "saddened" to discover that up to 1984, there were fewer than five percent of the total qualified accountants in the country who were Bumiputra.

It is notable also that in his written reply to questions sent to him, the former finance minister, Tun Daim Zainuddin, mentioned simply the following on the question "Who initiated the activation of the MIA?": "The Government of Malaysia." $\mathrm{He}$, on the night before the inaugural AGM of the MIA in 1987, had also mentioned what appeared to be the goals set by the government for the MIA to achieve (The Malaysian Accountant, Oct-Dec. 1987, p. 8): "As the Minister responsible for implementing the Accountants Act it is my hope that members of the Institute will make MIA an effective professional body responsible for looking after the professional standards, education and training and supervising over the professional conduct of members." He continued saying that cases of fraud in the corporate and financial sectors in the country had raised questions on the function played by the auditors. He pointed out that the auditors owed professional duty to the investing public to point out any illegal activity in the company and come out with appropriate audit reports. He stressed the following picture of what the government envisaged for the accounting profession: "As for the government, it would like to see an accountancy profession that is capable of providing professional work of the highest standard in serving the various needs of the sophisticated business community and to earn the trust and respect of society."

From those interviewed, very little however was mentioned about the MIA being activated to put to right the conduct of Malaysian accountants. Many interviewees had however mentioned that the real reason behind the activation of the MIA was nothing more than to have the MIA increase the number of Bumiputra accountants. One of the interviewees 
associated with the MACPA put it this way: the government had the motivation to help in activating the MIA because more and more Malay accountants had now came out from local and overseas higher institutions. The MIA would then be the right vehicle for the government to get these Malay accounting graduates registered and thus be recognised as qualified accountants in the country which aimed under the NEP for 30 percent of all professionals in the country to be Bumiputras by 1990. ${ }^{\text {xxxii }}$ A few others also pointed out that the MIA was activated because the government wanted it to deal appropriately with the unregistered accountants proliferating in an economy that was then about to take off. Somehow no one suggested that the MIA's activation had anything to do with the role of external auditors in dealing with white-collar crime.

The interviews had also uncovered various other reasons for the MIA to be revived which may be grouped under the heading "embarrassingly personal" in nature rather than had much to do with the national interests! These reasons included the MIA was used as a platform by one or two personalities as stepping stones for "better things in life" and that it was a vindictive act by certain personalities over their unhappiness with the MACPA leaders. From the viewpoint of those people interviewed who identified these "personal" reasons, there was little belief that national interests in the form of increasing the number of Bumiputra accountants, wiping out unregistered accountants, etc. were really the reasons behind the move to activate the MIA. A number of them also claimed that that the motivation for the MIA to become active was really from the accountants at the ground level and not the then finance minister or other parties in the government. Several interviewees identified these accountants to be local members of Australian accounting bodies, while others claimed that they were accounting graduates from local higher institutions. The reason these accountants wanted to revive the MIA was described in the interview by a council member of the MIA in the following manner:

For years the MIA members had not been happy to see the MIA lying low and letting the MACPA to take over things. And for years many accountants in the country were not happy with the MACPA which has been acting like a 'close-door' entity believing that their members are better than everybody else who are not chartered accountants or CPAs. It is wrong for the MACPA to close its 'door' to others simply because there are so many accountants in the country who could not get into the MACPA though they are well qualified to do so.

An interviewee who could be considered one of the leaders of the MACPA mentioned that local accountants mainly in the form of ACCA and ASA fellows who were not members of the MACPA were jealous of the MACPA members who controlled the market for public accounting in the country. This jealousy he claimed brought them to push for the activation of the MIA. What could perhaps be a little more controversial was the view disclosed by one interviewee: the MIA when it was activated was not considered by the government to be in the position to take over the various tasks done successfully by the MACPA to that date. From the government side, he said the MIA was to be a mere regulatory body with the main 
task of registering qualified accountants and ensuring more Bumiputra could be registered as accountants. The rest of the activity was to be left with the MACPA. The reply made by the then deputy minister of finance in October 1988 in the Parliament to a question by an MP on the subject of merger between the MIA and MACPA appeared to support this very stance. The then deputy minister of finance said that the government had decided on 17 June 1985 the date when the merger was rejected - that the MIA should continue to oversee the MACPA and other professional accounting bodies (The Star, 12 Oct. 1988; Business Times, 12 Oct. 1988). Both bodies he claimed had different functions and responsibilities. He also said that through the Accountants Act 1967, the MIA was set up to monitor, regulate and coordinate the accounting profession for the purpose of safeguarding public interest and ensuring high professional standards. Thus, as long as the MIA acted as a supervisory and coordinating body and did not compete with subordinate organisations, there would be no need for the MIA to merge with any other organisations. ${ }^{\text {xxviii }}$

Discussion. Following the occurrence of racial riots in 1969 and the implementation of the NEP in 1971, the MIA laid low and the MACPA thrived. But in the later half of 1980s, after the MIA-MACPA merger did not come about after years of discussion, the MIA came alive. Based upon available evidence presented above, it may be surmised that the activation of the MIA may be attributed to all three environmental factors: ethnicity, foreign investments and strong pragmatic government. While the presence of these environmental attributes were crucial in having the MIA activated, just like in the case of the MIA lying low, there was the occurrence of certain events that seemed to have prompted of such eventuality. In all probability, whereas in the case of the MIA lying low, the occurrence of the 1969 racial riots and the subsequent implementation of the NEP may be said to be the responsible prompters, the activation of the MIA may be directly connected to the occurrence of the two economic recessions in the 1980s. These recessions - especially the second one that took place in the 1985-86 compared to that of the first 1981-82 recession - had resulted with the private sector made to replace the public sector as the engine of growth. After a decade where the government played the role as the main engine of the nation's economy resulting with billions of ringgit of borrowed money allocated to various trust agencies which in turn made it possible for the establishment of hundreds of government companies (an estimated 900) in a variety of economic activities, the recessions had shocked the government and jolted it into introducing a number of new policy measures. Thus, in 1982, the government implemented a Structural Adjustment Programme (SAP) to reduce its external debts and the size of the government while increasing the role of private enterprise in the economy. Among the strategies promulgated included a substantial reduction in public development expenditure through the freezing of public sector employment for a number of years and the curtailing of development expenditure from 1983-onwards (Ismail Mohd. Salleh, 1994, pp. 621), tighter control over the NFPEs, privatisation and more incentives for and relaxation of rules on private investments. The following year, the Prime Minister unveiled the concept of Malaysia Inc., based on a partnership between the government and the private sector, to build a nation viewed as a giant corporation in which the two sectors have the task of ensuring the nation's 
success and sharing the benefits derived (Prime Minister Speech, 28 Feb. 1991; see also Mahathir Mohamad, 1985). To implement Malaysia Inc., since 1983, consultative panels have been established in most government agencies comprising representatives from both the public and private sectors to provide effective channels of communication between the two sectors (see Abdullah Abdul Rahman, 1991, p. 445). Later, the Fifth Malaysian Plan (1986-1990) emphasised public sector consolidation, rationalisation and completion of ongoing projects. It renounced new major public sector initiatives and instead placed greater emphasis on the private sector, calling for the "privatisation" of a number of government-held companies.

Perhaps just as important, at the wake of the 1985-1986 economic recession, the government intensified its efforts to attract foreign investors to the country's manufacturing sector. Thus, almost all NEP requirements were waived for export-oriented manufacturing industries. There was the de-emphasising of the restructuring prong of the $\mathrm{NEP},{ }^{\mathrm{xxxix}}$ which led to a more liberal treatment of private enterprise, especially direct foreign investment, and a softening stance towards restructuring the ownership of share capital of companies and raising the threshold for manufacturing companies so that they escaped the net of the Industrial Coordination Act (ICA) (Zainal Aznam Yusof, 1994, p. 597). ${ }^{\mathrm{xl}}$ With a few facets of the NEP pretty much set aside and the private sector was now to play the role of the engine of the economy, the government in the second half of 1980s began a series of programmes to facilitate the expansion of private sector business. These included the implementation of the various strategies to upgrade the operation of the KLSE, ${ }^{\text {xli }}$ changes taking place in the operations of the ROC ${ }^{\text {xlii }}$ and Inland Revenue Board (IRB) ${ }^{\text {xliii }}$ and a major amendment made to the Companies $\mathrm{Act}^{\mathrm{xli}}$. It was in such financial and regulatory context where now the private sector was to play the main engine of the nation's economy to replace that of the government that the MIA was found fit by the authorities to be activated to play the needed roles as promulgated in the Accountants Act passed two decades earlier.

Unfortunately, the MIA in the next ten years after its activation had not been that successful in showing the results that authorities and other interested parties had hoped to see (see Azham Md. Ali, forthcoming). In fact, it may be argued that the MIA had failed to achieve much as a regulator of the profession. Instead it had been preoccupied with various efforts to promote the profession. There was also no evidence that the MIA had in fact been trying very hard to increase significantly the number of Bumiputra accountants. Resources had instead been wasted in one rivalry episode after another with the MACPA and in fighting the unregistered accountants in quite a distressing manner. It appears that the rivalry between the leaders of the MIA and MACPA that began not long after the MIA's inaugural AGM in 1987 had culminated nearly a decade later with the passing of the Financial Reporting Act of 1997 which led to the establishment of the MASB to overtake the MIA's authority over the setting of accounting standards in the country. The episodes of the MIA-MACPA rivalry and the establishment of the MASB form the last two episodes of accounting development. In the case of the rivalry discussed next, the matter of ethnicity is argued by a number of interviewees to have played a role in bringing it up. In addition, the character of a government acting in a pragmatic manner may be traced. 
MIA-MACPA Rivalry. Less than a year after the MIA's inaugural AGM in 1987 where a total of nine CACA members compared to four from the MACPA were elected to sit in the MIA's fifteen-person council, the then president of the MIA went to the media mentioning that a group of people consisting of "officials of a smaller accounting body" were "out to do mischief" (NST, 22 Apr. 1988). He mentioned that these mischief makers ".... are quite big. They have vested interests because they feel they are not represented in the council." These people he said were collecting proxies to vote against the MIA proposed changes to be tabled at the EGM which was to take place in April 1988. A few days later he said that the "rival accounting group" did not want to see the MIA playing a greater role (The Malay Mail, 25 Apr. 1988). Needless to say, the then MACPA president when asked by reporters denied that it was the party referred to by the MIA president (The Star, 27 Apr. 1988). However, a few days later in the Utusan Malaysia (30 Apr. 1988), it was reported that the MIA told the newspaper that the parties which lobbied MIA members by conducting meetings to gain these members' support for their stance came from a professional accounting body which had been successful in influencing several large accounting firms to support their actions. And in the "MIA 1988 Bounded Document", it was stated specifically that the body was the MACPA (pp. 41-42):

Prior to the day of the EGM, a number of MACPA members came together to collect proxies in order to defeat the resolutions. MIA has got proof which shows that a number of meeting was held at the MACPA building to arrange the collection of these proxies. A number of MACPA council members have also attended these meetings. (Translated.)

Looking at what transpired during the EGM, there was no doubt that it was those from the MACPA who were the "trouble makers". As noted Yap Leng Kuen (The Star, 23 Aug. 1988), some MACPA members objected to various proposals to amend the Accountant Rules 1972. Four MACPA members consistently asked for polls, despite a clear cut majority by a show of hands and the fact that they knew they would be defeated every time. Later in July 1988, the then MACPA president came out with the proposal of the forming of an "accounting standards consultative committee" to develop and issue accounting standards and auditing guidelines (NST, 23 July 1988). In response, the MIA's chairman of the Financial Statements Review Committee (FSRC), Lee Hwa Beng, accused the MACPA of "usurping the statutory powers of the MIA". But, a few days later, the then MACPA president was quoted in the NST (26 July 1988) to say the following: "We have provided 30 years of excellent service, and we will continue to do so .... Like all other professional bodies, we have a role to fulfil. We have to ensure that professional standards set are maintained. We will continue to provide a forum for continued education and training." He was supported by Abdul Wahab Jaafar Sidek who mentioned the following (The Malaysian Accountant, July-Sept 1988, p. 15): “... the MACPA does not intend, as well does not need, to usurp the powers of any organisation .... the MACPA has, over the last 30 years, proven itself beyond any reasonable doubt." In response to all this, on the very next day, the MIA president was reported in the NST (27 July 1988) to have said that the MIA rejected the MACPA proposal. And he also asked the MACPA "to confine its activities to its members". He said that only the MIA had the statutory power to set the country's accounting and auditing standards. He 
pointed out that the MACPA “.... had to allow the MIA to take over the centre stage which was occupied by the MACPA during the MIA's dormancy." He also said that the time had come for the MIA to take over the centre stage. He was quoted to say that ".... while the MIA was very thankful and appreciative of the role the MACPA played in the past, the time had come for the MIA to play a major role in the profession in Malaysia." In the following month, he was reported to have said the following to the Malaysian Business (16 Aug. 1988, p. 20): "I am telling them (MACPA) in no uncertain terms that we now are the boss. No more the big brother-small brother relationship .... In fact, MIA is now the landlord, MACPA the squatter."

In an interview with one of the MIA council members, he noted similar things mentioned by the MIA president and which appears to be the crux of the continuing problem between the MIA and the MACPA. He claimed that the MIA was never against MACPA. He pointed out that "problems" arose when one MACPA president after another wanted the MACPA to play a bigger role which was only suitable for the MIA as the national accounting body to play. He also mentioned that the MIA did not actually care whether the MACPA was revamped or not; what the MIA would like to see was for the MACPA to stop "projecting" to the world that it was "the other" national accounting body. As far as the MIA was concerned, the MACPA could still be around as one of the "[Accountants Act 1967] schedule bodies" whose members' qualification was recognised by the MIA. He pointed out that among the accounting bodies recognised by the MIA, the MACPA was in fact the smallest in terms of membership. Thus, he stressed that the MACPA leaders should stop promoting the association as another national accounting body next to the MIA. This he said was not true in the past and certainly not true presently due to fact that a limited number of qualified accountants in the country being members of the MACPA.

The rivalry between the CACA-controlled MIA council and the big-six controlled MACPA council came to public attention with the MIA's EGM in April 1988. It was followed by a few other rivalry episodes which appear to have culminated with the formation of the MASB by the government to take over the accounting standard setting responsibility from the MIA in mid-1997. One of these rivalry episodes took place at the end of 1988 (NST, 8 and 17 Dec. 1988) and the other at the end 1993 (NST, 9 and 18 Dec. 1993; The Star, 8 and 15 Dec. 1993) when the opposing groups of members coming from the MACPA and the CACA were vying to have their members fill the six seats in the MIA council. In the case of the former, both parties had mentioned to the media that they aimed to control the MIA council because that would give them a better opportunity to look after their interests (The Star, 16 Nov. and 8 Dec. 1988). As for the latter, the rivalry appeared to be more serious where members of the MIA were personally approached to secure their vote and proxy votes were collected from those unable to attend (NST, 18 Dec. 1993). As claimed by an MIA council member, the MACPA which supported six accountants for the seats was out to "take over" the MIA (NST, 9 Dec. 1993). He was also reported to say that the MACPA's main aim in doing so was "... to re-assert its former controlling position in the MIA ...." (The Star, 8 Dec. 1993). In the same news report, the MIA president was reported to say that the group of six accountants was backed by some of the big six audit firms in the country. $\mathrm{He}$ accused these 
accountants who called themselves "reformers" as using certain issues to tarnish the image of the then MIA council. ${ }^{\text {xlv }}$ Besides these two episodes, one more took place in 1992 with the involvement of a third party the ROC. ${ }^{\text {xlvi }} \quad$ Also in 1992, another episode of rivalry began which only came to an end in 1994. From an interview with two MIA council members, it was only the involvement of the finance ministry that stopped the two accounting bodies from having their differences settled by the court. ${ }^{\text {xvii }}$

From both documents inspected and interviews, various possible reasons for the rivalry were found. From the former, it appears that the rivalry may be nothing more than competing attempts by two interested parties which wanted to be the sole leader in the nation's accounting arena. Yap Leng Kuen (The Star, 23 Aug. 1988) argued that the MACPA when incorporated in 1958 had appeared to consider itself as the de facto leader of the accounting profession in the country. The proof that that was the case may be found in several documented sources. In the late 1970s, the then MACPA president, Dr. Nawawi Mat Awin $(1979$, p. 5) had remarked: "At 21 , the MACPA is a truly comprehensive, truly national body of accountants. Recognised nationally and internationally, its activities cover a wide range ...." A few years later, the then MACPA president, Abu Hassan Kendut (1986, p. 3) said what appeared to be the case of the association viewed as a national body for accountants:

... the accountancy profession in Malaysia is governed by two separate bodies, the MACPA which is seen as an active professional body promulgating accounting standards and enforcing strict ethical rules of professional conduct, and the MIA (Malaysian Institute of Accountants) which is a government body created under the Accountants Act, 1967. The two bodies admit their members under somewhat different requirements and enforce somewhat different rules and regulations on the practice of the accountancy profession.

Even if the MACPA leaders do not believe that their association is quite in reality the de facto leader of the nation's accounting profession, that still seems what they want to be the case and what they are working on. In the MACPA 1985 Annual Report (pp. 13-16), the then MACPA president made this revealing remark: "A Public Affairs Committee was formed immediately after the last AGM to take charge of the PR aspects of the Association's activities. The Committee has developed a scheme, to be launched in stages, to increase public awareness of the accountancy profession and to position the Association as the leader in the profession." (Emphasis added.) But now after thirty long years with the MIA revival in 1987 as the statutory body to oversee the development of the profession, the MACPA leaders had suddenly found their association placed in a secondary role. This is a fact that the association leaders resented very much and which they would like to overcome with whatever means possible. Hence, in the "MIA 1988 Bounded Document" (pp. 44-46), the following was revealed: the MIA's problem with the MACPA began when a section of MACPA candidates were defeated in their attempt to sit at the MIA council at the first MIA's AGM in September 1987. Their dissatisfaction on not being at the helm of the MIA had led them to use all the power and influence to obstruct the MIA council from fulfilling the objectives of the MIA as stated in the Accountants Act 1967. This included making suggestion to the government to return the MIA back to its position before the activation as 
the registration body. Later, during the month following the MIA's inaugural AGM, exactly two days after the MIA council informed the MACPA council that they were setting up their own secretariat, the MACPA president and his fellow council members who were quite upset with the move called off the joint committee arrangement with the MIA (Berita MIA, January 1988, p. 12). ${ }^{\text {xlviii }}$

If from documents inspected there appeared to be relatively simple explanation for the trouble between the MIA and the MACPA, from interviews, it seems however that the rivalry has some deep-seated basis involving among others MACPA's closed-shop policy over the years and issues such as big versus small audit firms, chartered accountants versus certified accountants and race (Malay-controlled MACPA versus Chinese-controlled MIA). The presence of the first three reasons in contrast to the last one have certainly found substance from various documents. In the case of the MACPA's closed-shop policy, it appears that the CACA (MC) since the 1987 council's election had members who formed the majority in the MIA council membership. ${ }^{\text {xlix }}$ There appeared to be the fear on the part of the CACA members that if that did not happen, the MACPA which could then be in control of the MIA council would later come out with a rule demanding prospective members of the MIA to fulfil certain requirements such as sitting for some papers before they could be members of the MIA. ${ }^{1} \quad$ If that were to happen it would create unneeded obstacle for the CACA members to practice as public accountants or to be able to even call themselves accountants in the country. This fear had much substance for after all in the paper presented by the then MACPA vice-president, Megat Abdul Rahman (1979, p. 17), which discussed the proposal to merge the MIA and MACPA to form MICA, it was stated that members of foreign accountancy bodies would only be accepted as provisional members of MICA subject to "various limitations". These limitations were:

- They will not be eligible to enjoy the full membership rights.

- They will be considered for upgrading to associate status upon passing the necessary examinations and making up for any lack of experience which relate to local conditions.

In the July 1983 issue of the CACA Malaysian Chapter's official journal, The Certified Era, there were a number of remarks showing that the leaders of the CACA (MC) were more than a little worried about what would "hit" them if the MIA were to actually merge with the MACPA in 1985. It appeared that they were afraid that MICA would cause obstacle to CACA members (who would have to join MICA to allow them to be known and practice as accountants in the country) similar to what they had already experienced with regard to the MACPA from 1976-onward, with its various demands for foreign and local qualified accountants to sit for some papers, etc. before they could be its members. For example, in an interview with The Certified Era (July 1983, pp. 40-41), Datuk Sam Ah Chow who was then sitting in the Board of Advisors of CACA (MC) was asked what were his views on the proposed MACPA-MIA merger, he said:

In principle, the formation of a single National Body of accountants is good. What I am afraid of is the restrictions placed on foreign trained accountants on their admissions to the new body .... we should continue to keep the door wide open to foreign qualified 
accountants .... Other professional bodies in Malaysia like engineers, architects and lawyers still keep their doors open to foreign trained professional so long as they have recognised qualifications acceptable to the bodies.

Also in the same issue of the journal and under the heading "From the Secretary's Desk", it is notable that the then secretary of the CACA (MC), Soon Kwai Choy, who later became the MIA's vice president, made a number of intriguing remarks related to the MIA-MACPA merger proposal. One of them was the following (p. 15): "Menacing dark clouds hover above us in view of the uncertainty of the MIA/MACPA merger. Around those dark clouds we believe, there must be silver linings. It is this positive mental attitudes that Certified Accountants seem to possess in abundance that will take us through difficult straits. We have been through tougher times ...."

While the MACPA's closed-shop policy may be considered to have led to the rivalry, issues such as big versus small audit firms and chartered accountants versus certified accountants could also be considered to have played their role. Several interviewees mentioned that the conflict between the CACA-controlled MIA and MACPA was very much like those that took place between the accounting bodies in Australia, UK and other Commonwealth countries. It was not something so unexpected to have taken place in Malaysia. As noted by an interviewee who was a chartered accountant, the rivalry took place because certain people in the MACPA, including the few top Malay partners in the big six audit firms who were chartered accountants, viewed themselves as being of a higher status than those from the CACA (MC) who were certified accountants or for that matter any other accountants who were not of their chartered kind who were partners from small and medium sized audit firms. If indeed the problem between the MIA and MACPA actually originates from the age-old conflict between those of certified accountants (who are in charge of the MIA) and those of chartered accountants (in control of the MACPA council), one may consider that it is nothing to be surprised about. But from interviews with a number of MACPA leaders, they were those who stressed that the problem between the two bodies had racial intonation. That is in the sense that the rivalry was concerned with the vying for control of the majority of seats in the MIA council by two races: the Chinese Malaysian said to be educated in their mother tongue who were members of the CACA (MC) and whose leaders were now in control of the MIA council versus the Malays who were in control of the MACPA council. One of the leaders of the MACPA mentioned that the MIA now was in the hands of the Chinese Malaysian CACA members. When it was pointed out that the Chinese appear to be in control of the MACPA too due to their higher number in the association, he pointed out that at the MACPA council level, the Malays who were top partners of the big six still had the upperhand. So one could not say that what happened in the MIA was also happening in the MACPA.

It is notable that one other interviewee who could not be considered from either the MIA or the MACPA sides had also mentioned the significant influence held by the Chinese CACA members over the MIA. He early on said that the present like the past appeared to be very sad for the MIA. He then claimed: "Even today the MIA has not yet been able to project itself as the national accounting body." He said that this was because the MIA was flooded 
with the ACCA graduates who were mainly Chinese Malaysian. Thus, the CACA was in control of the MIA which in turn led to the situation where the MIA adopted a lot of the CACA-Chinese culture instead of what was supposed to be the national culture! He claimed that in the early years before and just after activation, the few MIA's Malay leaders headed by the Datuk Haji Hanifah were working on using the CACA to develop the MIA. There was the "win-win relationship" practised by the MIA president with the CACA leaders. Very soon after however the CACA leaders were using the MIA to advance the CACA! He claimed that the MIA's Malay leaders presently were in a hopeless situation. The hope he said was now placed in the local graduates who were largely Malays to come into the MIA as members to lessen the influence of the CACA's Chinese Malaysian leaders and members over the activities and strategies of the MIA.

Though more than a few interviewees stressed that the matter of race could explain why there were problems between the MIA and the MACPA, the two top CACA personalities in the MIA council who were interviewed had disclosed that from their viewpoint "race" was never a factor. One of them mentioned that what the MACPA had with more Malay people in the council was mere "facade!" He stressed that the Malay accountants were only "a front!" That was not the case with the MIA Malay council members. He also claimed: "The MIA has done more for the Malays than what the MACPA has done so far!" He mentioned that at the present time the MIA council was looking forward to get thousands of Malay accounting graduates to be its members.

It may be hard to deny that there is racial intonation to the rivalry between the MACPA and CACA (MC). But in deeper collection it could also appear that this racial factor has unnecessarily been made to look more serious than it really is by mainly the MACPA leaders and their supporters to gain support from the Malay politicians and other interested parties for what they all along are fighting for: the continuing dominance of the big six audit firms over the accounting profession in the country. The very fact that a number of the MACPA leaders are using the racial issue to be the basis of their rivalry is itself rather awkward. It is not as if over the years the MACPA leaders could in fact be considered "champions" of the Malay cause. As noted above in regard to for example the expansion of the number of Bumiputra accountants, the MACPA over the years could be said to have failed to take real actions on this issue. In the case of the CACA-controlled MIA council, over the years since MIA's activation in 1987, there are signs that they are somewhat sensitive to the needs and aspirations of the Bumiputras in the country. Nevertheless, an interviewee who is well informed about what was going on in both the MIA and MACPA claimed forcefully that there was no difference between what the CACA-controlled MIA and the big-six-controlled MACPA had done on this very subject matter. He also stressed that race should not be considered a factor in the problem of rivalry between the two bodies. The Chinese Malaysians he said were in control of both the MIA and MACPA. And both he claimed were not that sympathetic to the Malay cause. He revealed that from the point at which the MIA was activated the CACA members on the MIA council were not supportive of the efforts to promote the Malay Language and to increase the number of Bumiputra accountants. He also pointed out that the MACPA leaders over the years had failed to raise the number of 
accountants in the country and to ensure the greater use of the Malay Language among local accountants. He was very critical of the powerful Malay accountants in the MACPA who had failed to help the government in raising the number of Bumiputra accountants. He stressed that the MACPA was synonymous with the big six audit firms which in turn were owned by the non-Malays except in the case of the audit firm Hanafiah Raslan Mohamad (HRM). All in all, it appears that the MACPA leaders know that they would not gain support if they were to claim openly that they are fighting to ensure the dominance of the big six or that of the continuing purity of their "blue blood". So, they raise the racial issue, which in places other than Malaysia would perhaps not even be considered a reason for conflict between the chartered accountants and certified accountants. In Malaysia race is always an issue able to influence the people, and certain leaders of the MACPA have conveniently taken aboard the racial factor in their rivalry with the CACA (MC).

Discussion. The public display of the disagreement between the leaders of the two accounting bodies gained much publicity in 1988. As spelt out by Pauline Almeida (Malaysian Business, 16 Aug. 1988, p. 17), what happened surprised non-accountants. She wrote: "It thoroughly bewilders the public but the press loves the spectacle." She went on to quote the remarks made by a senior partner in a big audit firm: "'We used to be a gentlemanly lot' .... 'We preferred to crunch the numbers quietly and leave the talking to the lawyers. Now the profession has degenerated into politics - with a couple of jokers wondering how to outplay each other.'“ And yet the government which was noted as being responsible in getting the MIA activated did not seem to have done anything significant to improve the situation. Thus, Pauline Almeida, commenting that people were questioning the government's stance on the problems that arose between the leaders of the two accounting bodies, wrote (Malaysian Business, 16 Aug. 1988, p. 19):

As yet, there has been no official statements that openly indicate the taking of sides. That the Government would like to see unity has been made clear both a year ago by finance minister .... and more recently by deputy finance minister. But the situation is still shrouded in speculation. Loke's [deputy finance minister] careful words that no one accountancy body recognised by the Accountants Act is 'superior or inferior to the other' sheds little light.

Nearly a decade later, the Editorial to the business journal Malaysian Business (1 Aug. 1996) under the heading "A Profession Divided" referred again to the rivalry problems of the MIA-MACPA and made suggestion as to the role that the "authorities" should play in this matter. The Editorial began with the remark that "[i]t is a real shame that the accountancy profession in the country is divided" and ended with the following: "The authorities on their part, must make it clear they recognise only one national accountancy body. There can be no compromise on this."

The failure on the part of the government to do anything of consequence in regard to the rivalry problem is perhaps not surprising. This is because the government as a whole seems to have also shown little interest in the bigger issue of the failure of the MIA to be a true regulator of the accounting profession (see Azham Md. Ali, forthcoming). The government which could perhaps be expected to resolve this very matter in a decisive 
manner appears to have done little - until perhaps the ROC, from early 1997, sent its few officers to go around the country to check audit working papers of the audit firms. ${ }^{\text {li }}$ In fact, from early on, the government seemed to have confused matters so much on what exactly that it expected the MIA to do in the accounting arena. That is, while the then finance minister on the night before the inaugural AGM of the MIA in 1987 clearly delineated what was expected of the MIA (mentioned above), about a year later, at the time when the media was having a field day reporting on the public quarrels between the leaders of the MIA and the MACPA, his deputy made a remark in Parliament (which was also mentioned above) that gave the picture that the MIA was not expected to be a full-fledged accounting body. From several documented sources, it seems that the government was not happy with the MIA in its early years after activation and had in fact initiated some actions but never brought those to fulfilment. The government's half-hearted reaction to the MIA's self-regulatory failure in particular and the quagmire in the profession in general may be found in speeches delivered by the then deputy finance minister Loke Yuen Yow in July 1988 (which may be found as Appendix 12 in the "MIA 1988 Bounded Document") and later in 1990 (Akauntan Nasional, Oct. 1990, p. 21) and also the speech by the then finance minister himself in September 1989 (Akauntan Nasional, Sept. 1989, pp. 21-23). After the finance minister stepped down in 1991, it seems that not much could perhaps be expected from his successor. The person who replaced him as a whole who was also holding the post deputy prime minister had not been critical at the performance of the MIA as a regulator. In fact, he seems to have a high regard in Malaysia's audit firms (The Malaysian Accountant, June 1994, p. 14) and standard of financial reporting (Akauntan Nasional, Sept/Oct 1991, p. 23). It appears that since he took over from Tun Daim Zainuddin, only once - in the very year when he got hold of the post that he acted critical of the audit executed by local auditors (Utusan Malaysia, 19 Sept. 1991).

The failure of the government to solve the various problems in the accounting profession including that of the rivalry between MIA and MACPA has lend credence to the viewpoint forwarded by Belkaoui (1974, as reported by Samuels and Piper, 1985, p. 141). He said that a class elite in many developing countries is interested in maintaining secrecy. Thus, the financial reporting system was purposely made to be weak so that it was easy for this elite to maintain secrecy for their own gain. In the context of Malaysia, it may be surmised that those in power who should be able to make a difference have failed to do the necessary because it is not within the interest of these parties to see the emergence of a strong and respected MIA. Hence, just like in the case of the MIA lying low in the first two decades of its existence, these parties who continue to behave in a "pragmatic" manner have purposely failed to ensure that the MIA is capable of fulfilling its regulatory and other roles in the nation's accounting arena and instead is embroiled with the MACPA in one rivalry episode after another. Their lack of clear motivation and effort to ensure that MIA is not troubled by the MACPA and thus reaches its potential as a national accounting body may be associated with the fact that the state and those closely associated with it, such as the political parties and individuals, have seen little benefit from having an effective MIA due to their very strong and direct presence in the corporate sector. In fact, it might very well hurt their interests if there were to exist strong and respected accounting profession in the country. 
By late 1980s and early 1990s, even after a significant proportion of the economy has been transferred - under the so-called "privatisation" exercise - from the government to the private sector needing what is proclaimed to be an effective accounting profession, what appears to be the case is that much of the private sector is still in the hands of those associated closely with the government sector (see Edmund Terence Gomez, 1997; Jomo, 1995). This section of the private sector may even be considered as an "extension" of the government sector whose reigning politicians and political parties have for years been deeply involved in the business sector (see Edmund Terence Gomez, 1994, 1990; Leigh, 1992; Ho Kai Leong, 1988, Chapter Six; and Gale, 1985). There is merely a superficial rearrangement of ownership (Craig, 1988). Just as important as this very fact, the percentage of shares offered for sale in a number of privatised entities has also not reach above thirty percent of the total shares (Mohd Sheriff Mohd. Kassim, 1992): MAS, 30 percent; MISC, 17 percent; STM, 23.9 percent; and TNB, 22.8 percent. Therefore, through partial divestment of equity of government-owned entities, the government is still, at least in the case of those companies above, their major shareholder. Thus, it may safely be said that the need for a strong and respected accounting profession helmed by the MIA is still not as acute as would be expected if indeed a "new" political economic context had emerged after the two recessions in the 1980s. In fact, it appears that a weak accounting profession that is troubled by one rivalry episode after another and devotes more attention to promotional aspects than regulation suits certain parties, notwithstanding the rhetoric by a few among the power elite who stressing the need for improvements in practice, stricter enforcement of rules and regulations, etc. ${ }^{\text {lii }}$ It is a fact that for an activity such as accounting to reach its potential requires transparency in conduct, and a situation in which those making decisions can be held accountable. All these requirements do not fit the Malaysian environment as succinctly described in mid-1997 by the Editorial to the NST (7 June 1997):

At the pace of its economic growth, Malaysia, too will feel the vice of corruption sooner or later. Like others before it, this country will also try to look the other way, and do as much as it can to avoid rocking the economic boat. Like their Asian peers, politicians will trust to the moral superiority of a few good men to keep the others in line. And there is always the argument against washing dirty linen in public, the stubborn loyalty of politicians to their compatriots, and an equally obstinate belief that corruption is confined to an indiscreet minority. In politics, hard choices require courage and often pose uncertain risks - which is why politicians will try to postpone them until their hands are forced. The instinct of self-preservation will usually urge politicians to control the damage done by disclosures of corruption, rather than attempt to root it out. (Emphasis added.)

There were six reasons disclosed by the Editorial why corruption could be considered to have gone unhampered, and as disclosed by the Anti-Corruption Agency, corruption had been on the rise over the last 20 years and stiffer punishment was needed (New Sunday Times, 8 June 1997). Thus, it appears that what has happened in the accounting arena with the MIA continued to be embroiled with the rivalry problem with the MACPA has been deliberate and intended to deflect attention from creating a "culture of accountability" or full public disclosure, because interested parties - acting in a pragmatic manner - do not want to face the 
unnecessary "complication" of explaining themselves to anyone in their pursuit of gaining economic ascendancy.

On the whole, the rivalry problem between the MIA and the MACPA may or may not have racism as one of its main contributing factors. However, the environmental impact coming from a pragmatic government is clear in the manner that the problem continued to be unsolved by the end of the first decade of the MIA's active existence. With the laying out of Vision 2020 by the Prime Minister in 1991 (to be mentioned later), it appears that there is a continuation of the environmental influence on the accounting arena as found in the final episode of accounting development described next. Specifically, the influence from outside comes in the form of racial concern and strong pragmatic government over the establishment of the MASB and its parent body the FRF by the government.

The Setting Up of the MASB and FRF. The MASB and FRF commenced operations on 1 July 1997 with the passing of the Financial Reporting Act 1997 about six months earlier (NST, 11 July 1997). The finance minister had appointed Raja Datuk Arshad Raja Tun Uda, the executive chairman of Price Waterhouse, as the chairman of the MASB, while Tan Sri Wan Azmi Wan Hamzah, chairman of five KLSE listed companies, as the chairman of FRF. The former was one of the nine governing "members" of the Securities Commission and a former MACPA president, while the latter was a former MACPA council member. The Financial Reporting Act 1997 mentions that the MASB would have eight members comprising the chairman, Accountant-General and six others with experience in financial reporting and in one or more of the following areas: accounting, law, business and finance. Five out of these eight members shall also be members of the MIA. The Board is assigned three advisors coming from three regulatory authorities: Securities Commission, Central Bank and Registrar of Companies. As for the FRF, it comprises 18 individuals including a chairperson appointed by the finance minister. Six out of these 18 individuals are the following people or their representatives: secretary general of the Treasury, Central Bank Governor, Securities Commission chairman, Companies Registrar, KLSE executive chairman and MIA president. Another nine come from public listed companies (4), accounting firms (4), law firm (1). It appears that all the big six audit firms were represented with one in both the MASB and FRF through Raja Datuk Arshad, another four in FRF and the last one in MASB (Business Times, 9 July 1997). The functions of the MASB as listed in the Financial Reporting Act 1997 Act are extensive and include the issuance of accounting standards, reviewing pre-existing accounting standards to be issued as approved accounting standards and the development of a "conceptual framework". As for the FRF, it has the following four functions: to provide its views to the Board; to review the Board's performance; to manage the Board's financial affairs; and to perform any other function as the finance minister may authorise and which is published in the Government Gazette.

The MIA was against the formation of the MASB. The opposite was true when it concerned the MACPA. This was found from not only interviews, but also documented sources. The MIA's opposition was understandable: with the formation of the MASB, the ministry of finance would effectively pull out from the MIA the task in setting accounting standards. Thus said an interviewee who was a former president of the MACPA with glee: 
"The MIA is opposed to the idea of the MASB like mad!" During an interview, an MIA council member mentioned that the MIA had made a presentation at the ministry of finance to lobby against the setting up of the MASB - to no avail. In the presentation, the MIA "begged" the ministry to say what was wrong with the MIA in its accounting standard-setting efforts. The MIA also argued that it was the best party to handle accounting standard-setting since it did not have any vested interest in whatever way a standard came up to be. The MIA in short would be the independent party suited for such a task and not the MASB which would be comprised to some extent with parties from the listed companies, etc. who might do things to their benefits but which could damage the country somehow. With the creation of the MASB, several MIA council members stressed that the government was incorrect in taking away the accounting standard setting responsibility from the MIA. Now it appeared to at least one of them that the MASB was under the influence of big companies to the point that it would endanger the public interest.

From documented sources, it appears that the MIA's opposition began not long after the then finance minister in mid-1994 put forward the idea that there was a need to have an "independent" accounting standard setting body which was able to produce high quality accounting standards and whose standards were accepted by many including preparers, auditors and users of financial statements (The Malaysian Accountant, June 1994, pp. 14-15). This may be seen by the fact that later in the same year after this remark was made, the idea of forming Malaysian Accounting Standards Review Board (MASRB) was announced by the then minister of domestic trade and consumer affairs (The Malaysian Accountant, Feb. 1995, pp. 13-14). The MIA seemed to have played a role in getting the then minister to come out with this announcement because the minister's MASRB seemed to have gain the support from the MIA president. Thus, when the then MACPA vice-president mentioned that there was a need for the MASRB to be "not unduly influenced by any single group" (Business Times, 12 Dec. 1994), the MIA president responded by saying the following (Business Times, 19 Dec. 1994):

Any board formed under any other legislation, however independent it is dressed up to be, can only be viewed by investors - foreign and domestic alike - with suspicion as it would champion the vested interest of the members concerned. The vested interest can be that of the Government, big corporations or the auditors of big corporations who normally have their clients' at heart.

Ultimately the MASRB idea was scrapped. From the interview conducted with two MIA council members, it was found that the finance minister had instructed the ministry of internal trade and consumer affairs to stay away from the accounting standard-setting field since the former would do all that was necessary. With the idea of the MASRB rejected, the activity towards and against the formation of the MASB took centre stage. The NST (11 Sept. 1995) reported that in August 1995 the MIA had convened an EGM to discuss the issue of the MASB. The same news report had also quoted the MIA president as saying: "In the interest of the public and the country as a whole, we do not agree that the proposed MASB 
should be independent of the accounting profession and the institute." He proposed that instead of forming the MASB, it would be better to have the MIA's Accounting and Auditing Standards Committee to be upgraded as a Board with that of a review board was also set up to form an Accounting Standards Advisory Board (ASAB). The ASAB he said would greatly enhance the consultative process in accounting standards setting which many claimed was lacking at present. He also said that the ASAB would be comprised of the following: Accountant-General, ROC, chairman of SC, governor of Central Bank, chairman of the Federation of Public Listed Companies (FPLC), chairman of the National Chamber of Commerce and others which the authorities believed should be included. As if the MIA's concern and suggestions were not of any importance to the government which itself was responsible in having the MIA formed three decades earlier and which later in the 1980s was instrumental in having it activated, during his 1996 Budget Speech in the following month, the finance minister announced that his ministry would set up FRF and MASB as part of the government's continuing strategy to develop the capital market (NST, 28 Oct. 1995).

Early the following year, it was the turn of the MIA to ignore these remarks of his. The MIA members had passed a resolution at its AGM demanding their leadership make representations to the government to oppose the proposal (Accountancy, Nov. 1996). In January 1996, the Editorial to the MIA's official journal, Akauntan Nasional, spelt out the MIA's view in regard to the MASB. After saying that recently the MIA was elected to the Board of IASC which in its opinion meant that "Malaysia is held in high esteem internationally", it went on to say that at the local level the MIA did not get similar treatment. It further said the following: "A public announcement on the formation of the independent accounting standards board was made while the Institute strongly believes that the accounting standards setting process should remain with accountants .... The Institute is indeed facing an issue which affects the very core of the accountancy profession ..." In the same issue of the Akauntan Nasional (Jan. 1996, p. 6), the Companies Registrar who came under the ministry of internal trade and consumer affairs whose minister earlier announced the idea of MASRB was reported to have said among others that the setting of accounting standards should remain with the accountants via the MIA which had no vested interest and should not be meddled in by any other party. He also pointed out that though standards needed to take into account differing views, their quality and point of principles should not be compromised and that the wider "interest" of the investing public should come before those who would need to apply the standards. He stressed that the involvement of various parties would result in accounting standards losing their objectives. In the midst of stiff opposition from the MIA, the Securities Commission (SC), which appeared to be the body making the initiative for the formation of the MASB (Securities Commission 1995 Annual Report, p. 3), arranged for Sir Bryan Carsberg, the secretary-general of the IASC, to issue a set of statements to the local newspapers in 1996. In the NST (16 Oct. 1996) the following remarks by him "released" by the SC in Kuala Lumpur were reported: "The proposed formation of the Malaysian Accounting Standards Board indicates the need for standards to have a wider, public ownership beyond the narrower interest of the accounting profession .... This certainly accords with the worldwide trend in standards setting .... The Financial Accounting Standards Board is organised like that in the United States. The same happened in the United 
Kingdom ...."

From several documented sources, it appears that the MIA in trying to have the finance ministry to abandon the idea of the MASB had also initiated changes in the manner that its accounting standards were set out. Among others public hearings and fora have now been implemented. ${ }^{\text {liii }}$ Needless to say, these efforts by the MIA did not change the decision by the finance minister regarding the MASB. This could be due in considerable measure to the involvement of the MACPA leaders who included the top Malay audit partners from the big six firms. These auditors are those who have the interest of their big company clients in mind and who accordingly do not want to see the problems caused by the MIA on the goodwill accounting standard (described in Appendix 3) to recur. Furthermore, the MACPA leaders appeared to have been more than happy to ensure the MASB would come into existence due to the opportunity that the MASB would provide them with a means to side line the MIA in the area of accounting standard-setting. Perhaps as to be expected, not even a single documentary source has been found stating "directly" that the MACPA was heavily involved behind the scene. The best that gives hints on the association may be found in the MACPA 1995 Annual Report (p. 38) where the president said:

In reflecting the major issues facing the profession, I believe the most important challenge is the reform of the organisational and regulatory structure of the profession so that it is better placed to serve the members, the community and the nation. Your council has already undertaken some initiatives towards this objective, and I am hopeful that these will come to fruition in the years ahead. (Emphasis added.)

In the following year, the then MACPA president could also only state publicly the following (The Malaysian Accountant, June/Aug 1996, p. 17):

... the Minister of Finance has announced the establishment of a Malaysian Accounting Standards Board to formulate accounting standards and to identify areas of regulation and enforcement. The Association supports this development as it will ensure greater compliance with accounting standards by all parties who are responsible for the preparation of and reporting on company accounts. That will lead towards greater transparency to financial reporting.

Though hardly any written sources available pointing out the direct involvement of those from the MACPA in getting the MASB formed, from a number of other documented sources it may be safely concluded that the MACPA leaders were bound to be extensively involved behind the scenes. ${ }^{\text {liv }}$ In addition, the interviews revealed that the leaders of the MACPA had definitely played an important role in getting the MASB to be established by the finance ministry. Several MIA council members had claimed that to be the case; however, only two MACPA leaders elaborated on the role played by the MACPA. One of these two mentioned that several MACPA leaders went to the finance minister some time before the MASB came into existence in 1997 to talk about forming the MASB-like body which they argued was working wonderfully in the US and the UK. He claimed that the MACPA leaders' made that move because they resented the MIA's action in recent time which needed the big six audit firms to do the nitty-gritty work of accounting standards-setting while ensuring that 
leadership of the profession was in the hands of the audit partners from the smaller sized audit firms. He also claimed that the MACPA was very interested in having the MASB formed because "[t]he MACPA saw the MASB as a 'counterweight' to the MIA." $\mathrm{He}$ pointed out: "With the MASB, the MACPA has very cleverly cut the MIA's power by half!" He claimed that the MIA itself due to several episodes in accounting and auditing standards-setting had inadvertently helped the MACPA in getting the idea of the MASB through to the finance minister. These blunders he argued were not exactly unexpected of the MIA since the MIA did not have the "right people" in the area of accounting and auditing standard-setting. He claimed that majority of those sitting in the MIA's accounting standard-setting committee were from small audit firms which had limited interaction with big businesses. Another leader of the MACPA who also claimed that the big six was very influential in having the MASB established mentioned: "With the MASB, we have the presence of the very much needed non-accountants in accounting standard-setting. In addition, it is now the government which is in control and not some renegade accountants running amok in setting accounting standards in the country." He claimed that the government did not have much confidence in the accounting standard-setting effort of the MIA, and referred to three recent cases where the MIA's standards (two of them) and statement (one) were withdrawn due to some parties' criticism after they had already been enforced by the MIA. The two standards were related to goodwill accounting and to the expanding of auditor's responsibility for items appearing in a company's annual report. As for the accounting statement, it concerned certain items to be disclosed in consolidated income statements.

All in all, the involvement of the leaders of the MACPA in the process to form the MASB can thus be viewed as quite extensive. This extensive involvement should not perhaps be surprising since for years there appears to be quite a close relationship between the leaders of the MACPA and various government departments and agencies. This is in contrast to what is happening between the leaders of the MIA and those in the government. The close bond between the MACPA and the government may be seen from the following remark made by the then MACPA president which appeared in the MACPA 1983 Annual Report (p. 24):

I am happy to say that our Association continues to have close rapport with Bank Negara [Central Bank] of Malaysia, Ministry of Finance, Registrar of Companies, Director General of Inland Revenue, Director General of Insurance, Association of Banks and Finance Companies, Kuala Lumpur Stock Exchange, Auditor-General, Accountant-General, and Department of Cooperatives in matters where the Association could make meaningful contributions. On behalf of our members and Council I would like to express the Association's deep appreciation to these authorities for the confidence they have shown in us.

Similar remarks may also be found in numerous other MACPA Annual Reports (see for example the MACPA 1985 Annual Report, p. 18; the MACPA 1989 Annual Report, p. 29; and the MACPA 1990 Annual Report, pp. 23-24.) In the first half of 1990s with the stepping down of Tun Daim Zainuddin as the finance minister, it appears that the MACPA has been working harder to establish a much closer relationship with the government (see the 
MACPA 1992 Annual Report, p. 24; MACPA 1994 Annual Report, p. 19, p. 25). The close association of the MACPA and the government is certainly not seen in the case of the MIA and the government. In the MIA 1989 Annual Report (p. 7), the MIA president stated the following: "The Institute is being approached and consulted on various matters affecting the profession and the economy of the country, albeit not to the extent the Institute would like it to be." Later in 1993 he was quoted to say (NST, 5 May 1993): "Our regulatory role has been undermined by the lack of cooperation and understanding from certain Government departments and agencies." In that news report he also said that although the MIA was appointed by Parliament to represent all accountants in the country, it did not receive due recognition as the national body of accountants. This he said was especially evident in dialogues, representations and meetings when recognition had been persistently accorded to the MIA's component body (MACPA of course!). He said that the MIA should be viewed as the "sole" medium for communication and discussion for the accounting profession. $\mathrm{He}$ urged the government departments and agencies to recognise MIA's position as the national accounting body. Also in 1993, Tony Seah, an MIA council member and a chartered accountant mentioned that one of the problems faced by the nation's accounting profession was the lack of support from the government. He stated that the MIA as a professional body should be able to contribute to the promulgation and implementation of government policies which affected the nation's accountants and the public. He then said the following (Tony Seah, 1993, p. 7): "The problem then is how do we get the government departments and the government to listen to us and for us to be consulted. The challenge must be to position ourselves in the right place for consultation and more importantly for our views to be considered."

No documented sources were found that may explain the reason(s) for the detached relationship between the MIA and the government which culminated in the formation of the MASB by the government. However, the interviews have found a number of reasons including one which is quite racial in nature. In interview two of the MIA council members claimed that they could not compete with the MACPA which seemed to have more influence in the government sector because the MACPA had been active longer compared to the MIA. As a result, the MACPA had cultivated a network of supports in the various government ministries, agencies, departments, etc. It is hard to believe however that this explanation on its own is sufficient. Thus, one interviewee who may be considered as one of the leaders of the MACPA claimed that the finance minister was unhappy with the MIA council members because its leaders had the tendency to "politicise" issues and because of their public statements on various issues. He even claimed that the minister did not believe that the MIA should have the power over accounting standard-setting. He claimed the minister could not say this openly because the MIA was established by a Parliamentary Act. He also claimed that the finance minister had a warm relationship with the MACPA and thus supported the formation of the MASB and did not really have a good relationship with the MIA for a reason more racial in nature. The MIA was known by the finance minister to be in the hands of the ACCA accountants who were mainly Chinese whereas that of the MACPA was controlled by Malay chartered accountants who were top partners of the big six audit firms. He pointed out that although it was true that the MACPA had many Chinese, the council was in 
the hands of the Malays. This he claimed had made the Chinese Malaysian members of the MIA quite antagonistic towards the MACPA and in turn pushed the finance minister who was a Malay to be supportive of the Malay-controlled MACPA council.

The extent to which these arguments are true could not be definitively ascertained due to the fact that there are no written documents found which mention them. Other interviewees were also reluctant to say what really went on between the MIA council members and the finance minister. However, with the formation of the MASB where the influential individuals associated with the MACPA appear to be given the upper hand compared to those in the MIA, the finance minister and thus the government showed that they have little concern for the MIA and its opposition. In addition, the fact that the person who uttered those words bringing in race as one of the factors to be considered was closely involved with not just the MACPA but also those in the government could only strengthen the possibility that much of what he claimed to be the case was indeed based upon informed inside knowledge of the feeling of those in the government. In other words, his arguments can be regarded as credible. But just like in the case of the MIA-MACPA rivalry, the possibility that "race" is not quite a significant factor is still there because it appears that another strong reason exists as to why the finance minister is close to the MACPA leaders and not those of the MIA: the finance minister and his colleagues in UMNO and UMNO itself are known to be closely associated with big businesses which may be easily affected by the "wrong" policies of the MIA (as illustrated in the case of MAS 6 described in Appendix 3). Since the MACPA leaders have also significant interest in the fate of their big company clients, there exist mutual interests between these leaders and the finance minister. Thus, race as an argument for the finance minister to be on the side of the MACPA leaders may not be so significant as that which is more materialistic in nature: the continuing prosperity of all those who are already in the position of privilege in the Malaysian society and in particular in the Malay community.

Discussion. It was in February 1991 when the Prime Minister unveiled the government's future broad policy priorities to make sure that Malaysia will become a fully developed and industrialised country by the year 2020 (Mahathir Mohamad, 1991). This long-term plan is called Vision 2020. ${ }^{\text {lv }}$ To achieve a developed economy status by 2020 , a sustained annual growth of 7 percent from 1990 to 2020 is planned by continuing with the policy priorities implemented in the 1980s, such as privatisation, greater foreign direct investment (FDI), capital market reforms and reliance on the private sector for economic growth. In regard to the capital market reforms in particular, these need to take place so that the capital market could play a greater role in funding the operations of businesses. ${ }^{\text {lvi }}$ It is notable that in 1995, the "disclosure-based regulation" which gives great emphasis on high standards and levels of disclosure had replaced the "merit-based regulation" when amendment was made to the Securities Commission Act of 1993 (see the Securities Commission 1995 Annual Report, pp. 85-90). Hence, the following year, in the midst of stiff opposition from the MIA over the idea of MASB, the finance minister mentioned that for the country to strive for "disclosure-based regulation" of its capital markets to lead towards "a financial reporting environment of international standard", the financial reporting standards "must" be accepted 
by the business community and not just by the accounting profession (NST, 8 Oct. 1996). He also argued that in many countries the accounting profession together with the preparers, users and regulators had recognised that high quality accounting standards would emerge with the active participation of the relevant parties and that the process being made "independent" of any particular interest group including the accounting profession (Business Times, 8 Oct. 1996). He stressed that a mechanism was needed that allowed the involvement of all relevant parties in the financial reporting process. What he had conveniently forgotten to state was however starkly cleared to those from the MIA. As mentioned by a member of the MIA council in the interview, Malaysia appeared to be the only country where the government went on to set up an accounting standard-setting body though there already existed an accounting body formed through Parliamentary Act to do the task. He said that from a study conducted by the MIA, it was found that only New Zealand came close to what Malaysia was now having with the MASB. However, he stressed that the body in New Zealand was to "review" financial statements and not to set accounting standards. He also said that accounting standard boards were formed only by countries like the US, the UK, and Australia where there were multiple accounting bodies operating which did not agree among themselves regarding the standards to be adopted.

This very fact that was for one reason or another not told to the Malaysian general public makes it quite probable that the setting up of the MASB is very much an effort to satisfy hidden agenda. Specifically, the real reason is to ensure that big six audit firms controlled by the Malay partners are able to reestablish their dominance in accounting standard-setting following the taking over by the MIA of the MACPA role as the body to represent the nation's accountants after the activation of the former in 1987. Now that they are in charge of the MASB and the FRF would in turn ensure that the interests of the big businesses controlled by the government or its affiliates could go undisturbed. This very interests were nearly damaged when the MIA issued MAS 6 on goodwill accounting a few years earlier (see Appendix 3). The fact that those from the big six have established close bonds with those in the government, in particular the finance minister, is a general knowledge. Years ago, it was the audit firm Hanafiah Raslan Mohamad (HRM) which came to be in the government's goodbook. In fact, HRM would not have even been set up in 1964 without the encouragement coming from Tun Abdul Razak who was then the deputy prime minister (later the second Prime Minister) (Malaysian Business, 16 Aug. 1988, p. 13). When the 1970s arrived with the government played out a much bigger role in the economy, HRM, being the only "Bumiputra accounting firm" around, was hired to audit the burgeoning number of public enterprises and other government entities (Malaysian Business, 16 Aug. 1988, p. 13). From 1973 to $1988 \mathrm{HRM}$ was the local affiliated firm for Touche Ross International. In 1990, it merged with Arthur Andersen \& Co creating close to 1,000 personnel and making it the Malaysian member firm of the Arthur Andersen worldwide organisation. The merger created the biggest local practice in terms of revenue, personnel and geographical coverage (The Star, 13 Apr. 1990). It is notable that Arthur Andersen/HRM was the audit firm which famously made a donation of RM 1.7 million in 1997 to the International Islamic University (IIU) for the setting up of the Arthur Andersen chair (NST, 26 Feb. 1997). This donation that in terms of the ringgit amount involved appeared to have never been made before by any 
audit firm to a local higher institution was in addition to a half million ringgit that it donated to the IIU in 1994. The one who received the RM 1.7 million whose picture came out in the NST (that is in those days owned by those who were also closely associated with him too) was none other than the finance minister who held the post of president of IIU. From interviews, it was found that the audit firm Price Waterhouse has taken over the position of HRM in being very close to those in the government. Its executive chairman as mentioned above is one of the commissioners for the Securities Commission and head of the Malaysian Accounting Standards Board (MASB). This person was also a classmate of the finance minister during their schooling days at the "Eton" of the East (Malay College Kuala Kangsar). The closeness of the relationship between the two was not found in documented sources. However, the former has hinted publicly on the strong bond between MACPA and the finance minister by saying the following at the end of his speech as the then president of the MACPA at the MACPA 36th Annual Dinner with the finance minister and wife in the audience (The Malaysian Accountant, June 1994, p. 14): ${ }^{\text {lvii }}$

To the Most Honourable Dato Seri Anwar Ibrahim who has given close attention to the Association and to the Datin Seri who has always given her cooperation by attending the various functions of the Association, I like to say millions of thank. These gestures will be forever treasured. Your kind support and advice will indeed be one of the pleasant memories of the Association that I will greatly cherish for many years to come.

Note that it was also on the same occasion that the finance minister had showered praises on the country's (big) audit firms. He said (The Malaysian Accountant, June 1994, p. 14):

The accounting fraternity in Malaysia has come a long way since the early days of independence, when much of the industry, like the rest of the economy then, was dominated by foreign firms. Since then, the industry and the country in general has grown. And in the process, the industry has matured and attained a definite Malaysian character, with local firms playing a leading role in shaping the future of the industry. Indeed, local accounting firms have gained international recognition for their high standards of professionalism and expertise, standards that are amongst the best in the region.

As if the fact that MASB and FRF are handed to the big six audit firms is not enough to ensure that these firms got back their eminent position in the nation's accounting arena thus ensuring the continuing protection provided to big businesses that they audit, with the passing of the Financial Reporting Act, the finance minister himself (whose affiliates are known to be heavily involved in the corporate sector) is given considerable authority over the practice of financial reporting in the country. For example, Section 15 notes that the minister's directions to the Foundation and the Board in regard to their respective functions and authorities need to be "listened" to and that both the FRF and MASB will have to report their activities to him when they are required to do so "from time to time". And Section 29 of the Financial Reporting Act 1997 notes that "[t]he Minister may make such regulations as may be expedient or necessary for carrying out or giving effect to the provisions of this Act." Thus, it may safely be said that besides ethnicity, the character of the government of being strong and pragmatic may be found in all this discussed so far. 
The government's pragmatism and high handed manner may also be traced in the way that it handles the subject of the enforcement of the accounting standards issued by the MASB. It was in 1994 when the finance minister first raised the subject of an "independent" body to develop accounting standards that he said the following (The Malaysian Accountant, June 1994, pp. 14-15): "I believe the time has come for us to consider the establishment of an Accounting Standards Board backed by a body which can ensure stronger arrangements for securing compliance and which has the financial resources." And later during his 1996 Budget Speech mentioned earlier, he said that the establishment of MASB to formulate accounting standards and identify related areas of regulation and "enforcement" would ensure a high level of financial reporting and disclosure in the corporate sector (NST, 28 Oct. 1995). And yet there is no direct statement in the Financial Reporting Act 1997 or elsewhere on the enforcement activity of the Board whose standards (as stated in the Financial Reporting Act 1997) are compulsory for any published accounts of a business entity in Malaysia and its overseas subsidiary or associated companies where the latter's accounts form the consolidated accounts in Malaysia. The best that may be found was the remark that the finance minister had made in 1996 where he mentioned that the FRF and MASB would be supplemented by appropriate compliance and enforcement mechanisms of the ROC, Central Bank and SC (Business Times, 8 Oct. 1996). Unfortunately, he did not go into detail how they would conduct these very important activities. With the ROC having little expertise in accounting and auditing, nothing much has been heard on the Central Bank's enforcement activity ${ }^{\text {liii }}$ and the fact that to date the SC has hardly shown any interest in companies' financial reporting, it is uncertain as to how far these regulators will be effective in their enforcement activities. Overall, there is a threat that with or without the MASB, the future state of financial reporting - assuming little intervention from the recent "Asian Financial Crisis" - will continue much as it was when the MACPA and later the MIA controlled regulation of practice.

Perhaps the government's pragmatic manner in not ensuring that the MASB's accounting standards would be properly enforced may be understood by the very fact mentioned earlier that came from Belkaoui (1974): the propensity of a class elite in many developing countries to ensure the financial reporting system is weak so that it was easy for them to maintain secrecy for their own gain. In other words, in the context of Malaysia, those in power and their affiliates - whose very strong and direct presence in the nation's corporate sector is not a secret - have failed to ensure that standards issued by the MASB to be properly enforced so that the status quo may be maintained. It is true that the stock market has been quite active in recent years. But it is also true that Malaysia just like other High Performing Asian Economies (HPAEs) still find that their bond and equity markets had played a relatively small role in financing their business activities (World Bank, 1993, pp. 223-227). ${ }^{\text {lix }}$ In the case of Malaysia in particular, the World Bank (Table 5.8, p. 225) notes that in 1986-91 period, the financing of its nonfinancial corporations came primarily from internal sources (58.8 percent) and loans (36.8 percent), while the equity market supplied a mere 1.8 percent and no percentage was shown at all under the bond market. So, when the stock market is not the major entity contributing funds to companies, as noted Radebaugh and Gray (1993), the accounting practices will tend to be more conservative and disclosure will 
be limited. ${ }^{\mathrm{lx}}$ Also note that Meek and Saudagaran (1990, p. 150) propose that disclosure levels tend to be higher when there is a large number of capital providers, when their information needs are diverse, and/or when they have a remote relationship with the business. On the other hand, disclosure levels are lower when businesses rely on relatively few sources of capital with similar information needs and which maintain a close relationship. Under the latter situation, the capital providers have direct access to whatever accounting information is needed and extensive public disclosures are not necessary. And for that matter in the case of Malaysia, there is no real and urgent need to have the MASB's accounting standards to be strictly enforced.

Capitalism per se does not require full disclosure in financial reports. This is especially the case when the capitalism one refers to is the cooperative, insider or crony type (see Yoshihara Kunio, 1988). All in all, it may safely be said that the fact that Malaysia's corporate environment and culture is not yet in a position to have the accounting standards of the MASB to be strictly enforced has led to a situation that although a new accounting body is now in the picture, its effectiveness in ensuring companies' compliance would not be expected to be much better than its predecessors the MIA and the MACPA. Sterling (1974), Hopwood et al. (1988) and Burchell et al. (1985) among others mention the significance of government and the state in accounting related matters. Sterling provides the picture of interference by an otherwise neutral government compared to the latter two which suggest that the state - through its involvement in the administration of war, the management of national economic planning and concerns for greater accountability - has been actively involved in the development of accounting practices. In the case of Malaysia, it may be deduced that the government's pragmatism has ensured that its involvement over the years in accounting matters is half-hearted. In other words, its participation is related directly to the creation of the various modern institutions themselves such as the MIA and MASB, and not to the need for their effective and appropriate administration. As a result, the so-called changes occurring in accounting are more ephemeral than real, structural rather than in-depth.

By and large, the aspiration to be a developed country by the year 2020 is mixed with the quality of a nation steeped in the old debilitating ways and where the mentality and actions of many participants in the social, economic and political life seems to be leading not to a developed nation status but instead to continue with the old manner of doing things. The nation's accounting arena at the onset of the "Asian Financial Crisis" in 1997 in particular is mired in its past, present and future outlooks. Much of the activity appears to be the result of the fact that a very small section of the society holds so much power in the political and economic sector. Notwithstanding their rhetoric, it may safely be said that they have little interest in seeing changes in the status quo. As Rohwer (1995, p. 281) in his acclaimed work on the rising of East Asian nations had noted, "... elites do not normally reform themselves or do things to threaten their own position." On the state of accounting standards applied in these countries in particular, he stated (p. 292): "For the most part, regulation and disclosure standards are not at rich-world levels; even when they look good on paper, the standards are not forced with the same zeal that they are in the West." It may be concluded that as long as very little actually changes in the manner that political and 
economic power are distributed among members of the Malaysian society, the so-called change from a predominantly command-economic system in the 1970s (where the MIA laid low while the MACPA thrived) to a more capital-market economic system in the late 1980s and beyond (where the MIA revived but troubled by the rival MACPA) would not really make much difference in the manner that accounting developed in the country. It is submitted here that accounting in Malaysia just a few years prior to the emergence of the new millennium is fraught with the uncertainty of a nation that is looking to the future with much hope and expectations but whose ties with the past are still very strong. Accounting like the country itself remains at a crossroads.

\section{Conclusions}

With interpretivism as the line of inquiry, the emphasis is on the context surrounding the subject matter under study and the relative reality of concerned parties. It should lead to a broader if not an alternative conception of accounting compared to that written from a functionalist perspective in a normative manner. Specifically, this work tries to understand how political, economic and social conditions and related institutions have impacted accounting development in Malaysia. In other words, accounting is understood to be interrelated with the dynamics of the wider sociopolitical and economic context of which it is an integral part. This is the very view where knowledge of accounting is enhanced by looking at accounting, the discipline and its research, as socially constituted (Lehman, 1985, Chapter 3). Under the socially constituted approach, it is considered that there exist various forces that shape and direct accounting practice under different social regimes. Accounting is not a natural phenomenon that is independent of human beings, rather it is a man-made system that is continuously changing within its environment. Accounting is in short considered as social practice imbedded in a socio-historical context. In the context of Malaysia, specifically it is found that distinct environmental factors have impacted accounting activities. Racial concern and strong pragmatic government in contrast to foreign investments appear to pull back any hope for much progress in the manner that accounting has been developing in the country. Thus, as stated by Hopper et al. (1987), accounting development has been implicated in broader ideological and political struggles in the society.

In the setting up of the MIA by the government and the ICAEW-mirrowed MACPA by the private sector, the environmental attribute of foreign investments appears influential. This perhaps is to be expected when the nation's economy under the immediate post-colonial government had changed little from that under the British colonial administration. The British and other foreigners were still in control. Furthermore, the investments that were needed in manufacturing were also coming from relatively the same sources: the British and other foreign capitalists. But with the launching of the NEP in the early 1970s, where the government now played quite a significant role in the nation's economy, in the next one a half decade, the MIA laid low while the MACPA thrived in a rather taxing manner. Both episodes may be attributed to the environmental factor of strong pragmatic government which did not see the need for the presence of a strong and respected MIA, but which considered an active MACPA whose activities catered to a section of the nation's accountants population 
was needed in the interests of foreign investors. The MIA lying low may also be attributed to some extent to the environmental attribute of ethnicity, while in the case of the thriving MACPA, foreign investments.

With the occurrence of the two economic recessions in the 1980s, the government was forced to hand over the role of being the engine of the nation's economy to the private sector. Therefore, where before growth was based on expansionary public expenditure, from at least the mid-1980s onward most of the economic growth was to be due to private sector activities. It was within this economic context that the nation saw the MIA-MACPA merger proposal rejected by the federal cabinet in 1985 and subsequently the revival of the MIA in 1987. The rejection of the merger proposal may be attributed primarily to the ethnicity strong influence. In the case of the activation of the MIA, all three factors seem to have come into the picture. In particular, with its activation in the 1987, the MIA was implicated in the effort towards having greater involvement of the private sector, including those from overseas, in the nation's economy due to the proclaimed need for a strong and respected accounting profession for such an economy. The MIA was also needed to be active to ensure that it would play the needed role of giving full recognition to local accounting graduates, who are in the majority Bumiputra, and thus lead to greater Bumiputra participation in the accounting profession. For these reasons, it may safely be said that the government also showed it was acting in a pragmatic manner. There did not seem to be any all-binding ideology providing guidance here. It was all what considered fit to take place to match what went on in the nation's socio-economic political environment then.

But after a decade of being active, the MIA had not seemed to be a significant partner in attracting foreign investments into the country and it surely had failed to achieve much in getting more Bumiputra to be recognised as qualified accountants. Instead, the activation of the MIA had ensured that the MIA for the next ten years was wasting its resources in one rivalry episode after another with the MACPA. This rivalry as claimed by a number of interviewees may be attributed to the presence of racial factor. Just how far race is the real issue is not that easy to decipher. What however is very hard to deny is the outcome of this rivalry: the setting up of the MASB and FRF by the government in mid-1997. Having the MASB and FRF set up does not however seem to mean that the actual state of the nation's corporate financial reporting would improve. This is because of the apparent neglect by those in authorities in ensuring that the formation of the MASB to issue accounting standards is coupled with the need to have it or other related entity to enforce the standards. Thus, the setting up of the MASB and FRF which may have been pushed by the matter of ethnicity and strong pragmatic government was perhaps just a device to bring back top Malay partners from the big audit firms to be in charge of the responsibility to issue accounting standards that for nearly a decade earlier was in the hands of the Chinese-controlled MIA. With that very action, the nation's elite may be assured that their unbridled conducts in financial reporting and related matters which match their strong and direct presence in the corporate sector shall continue as before.

The power held by the elite in the nation's economy is not hard to decipher. During the NEP era, in a study by Sieh Mei Ling (1977) of the top 98 manufacturing companies in Malaysia 
in 1974-75, it is found that one percent of the over 100,000 shareholders accounted for almost 80 percent of the shares held, worth a total of about RM 1.2 billion (see also Sieh Mei Ling, 1982). Also, Lim Mah Hui (1981) in his study of share ownership of one hundred largest companies in Malaysia, 1974-76, reveals that it was highly concentrated in the hands of a few institutions. The share ownership of these institutions were in turn concentrated in the hands of a few individuals and families through interlocking directorates. He concludes that the Berle-Means (1932) thesis of management control rather than ownership control could not be applied to Malaysia without strong corrective and empirical analysis. A decade later, the situation remained the same. Chandra Muzaffar (1989, p. 84) notes that in 1983 a large proportion of the top 797 stock-owners were Chinese and one percent of them accounted for 32.23 percent of the value of shares whereas the bottom 50 percent accounted for only 1.92 percent (see also Lim Mah Hui, 1983 and Ozay Mehmet, 1986, Chapter Five). In the late 1980s, when many facets of the NEP were amended, a study done by the KLSE also found similar results: 87.5 percent of the paid up capital of 225 Malaysian incorporated companies as at 31 December, 1987 was held by 8.1 percent of shareholders who held more than 10,000 shares each (Kuala Lumpur Stock Exchange, 1988, p. 22). Based on the same data, Salleh Majid (1989, p. 4) stated that on average, 75 percent of the equity of each company were normally held by the 20 largest shareholders. In the 1990s, no study had apparently been conducted to find out the extent of their share ownership. In all probability however, it is not expected that the extent of the elite's share ownership would be that different to that which took place in the previous two decades.

Since 1994, the number of new companies registered yearly in the country was roughly 40,000. In 1993, there were 277,018; and in 1996, there were more than 404,000 companies (Business Times, 18 Sept. 1996). ${ }^{\text {lxi }}$ Recently too the local stock market has expanded tremendously. In 1993, its daily trading averaged 800 million shares compared to around 3 million shares two decades earlier (NST, 21 May 1993). At the end of 1993, the market value of the KLSE rose to RM 620 billion - an increase of 152 percent from the RM 246 billion recorded at the end of the previous year (NST, 14 May 1994). In 1993 too, the total volume and turnover rose to 108 billion units valued at RM 387 billion, which exceeded the combined volume and turnover for the past 20 years. In 1994, the International Finance Corporation, an affiliate of the World Bank, posted in the Internet that the KLSE's market capitalisation as at November 1993 was US\$175 billions - the second biggest after Hong Kong among 22 emerging markets capitalisation. The number of listed companies at the KLSE had also increased from 187 in 1981 to 282 in 1990. In 1992, it increased to 321 (Parker, 1994). At the end of 1993, the number increased to 413 companies and by the end of 1995 to over 500 companies. Nonetheless, even with all these encouraging numbers, the local corporate scene is filled with individuals or companies owning at least 51 percent of the shares of the so-called public companies - including those listed at the KLSE. The NST (30 May 1994) reported that more than two-thirds of the 335 companies on the main board and all of the 92 on the second board were controlled either by one or a few shareholders with more than 51 percent of the shares. This domination is not illegal since the KLSE listing rules require no more than a public float of 25 percent of the total shares issued. 
Therefore, the listed companies still remain as private companies (Salleh Majid, 1989). They are public and listed only in names. Many of the listed companies were labelled by chairman of the Malaysian Institute of Economic Research (MIER), Datuk Dr. Kamal Salih, as "private-owned public company" (NST, 21 August 1991). Most shares were still held by insiders - family members, friends, clan members and others known personally to the companies' founders. And when it concerns the privatised government companies including those which are listed at the KLSE, majority of the shares as mentioned earlier are held by government entities. Therefore, in the whole, the "principal-agent" dichotomy does not exist or is at best blurred in the Malaysian context. Even though more and more companies are formed in recent time, while a number of them is listed at the KLSE, these were "companies" merely in name. In such context, nothing much may thus be expected from the owners/managers.

In particular, owners/managers of local companies have the tendency to flout established principles of the proper manner to operate companies, are reluctant to disclose much and quite discriminatory in the issuance of the annual reports. Regarding their tendency to flout the laws, in 1992, the ROC collected RM 7.39 million in penalties from 24,241 convicted companies compared with RM 8.49 million from 13,148 companies in 1991 (NST, 19 Feb. 1993). The majority of these convictions were derived from failures to convene AGMs or present the financial statements to members. In 1993, it was reported that a total of 67,000 companies were hauled-up by the domestic trade and consumer affairs ministry for the same transgressions (Business Times, 30 July 1993). The ministry had imposed fines between RM 200 to RM 2,000 on each offender, while 126 companies' directors had been charged in court for serious offences. And between January and August 1996, a total of over 30,000 fines valued at nearly RM 8 million were issued to errant companies by the ROC (Business Times, 18 Sept. 1996). About 70 percent of this amount was due to failure or delay in the tabling of their accounts at AGMs and sending in their annual returns and other documents to the ROC.

As for the reluctance of these owners/managers to disclose much in the financial statements, a number of anecdotal evidence is available. Dr. Barjoyai Bardai mentioned in his newspaper column (Berita Minggu, 25 July 1993) that very little information was disclosed in companies' annual reports with the companies using the excuse of safeguarding "trade secret". And those that were in fact disclosed were of limited usefulness. Later in 1995, the then minister of domestic trade and consumer affairs mentioned that "[m]any companies still think that the Annual Report is done just to satisfy statutory requirements and, hence, submit a report with minimal disclosure" (The Malaysian Accountant, Dec. 1995, p. 17). Besides these anecdotal accounts, an empirical study by Tan Liong Tong et al. (1989) on voluntary disclosure of selected items in listed Malaysian manufacturing and industrial companies' annual reports showed that the level of disclosure was very low. Out of 25 items compiled on several scales of importance, only 12 were disclosed or commented upon and out of these 12 , only one item was disclosed by more than 56 percent of the companies and three items by more than 40 percent of them. Nearly a decade later, Tan Liong Tong and Chew Tek Ann (1996) did research on voluntary disclosure in the income statements of 120 
KLSE main board listed companies (as of December 1993) selected on the basis of stratified random sampling technique. They found a high level of non-disclosure: about 79 percent of the total value of all charges or credits between turnover and profit before tax of Malaysian companies were not revealed. Finally, as if the failure of the owners/managers of local companies to comply with the law and to disclose much is not already so bad, another debilitating conduct of theirs is concerned with the treatment they provided to a section of their shareholders. Note the following related to the issuance of the annual reports to these shareholders coming from the then minister of domestic trade and consumer affairs (The Malaysian Accountant, Feb. 1995, p. 13):

... companies should not practice double standards in distributing their annual reports. Although it is appreciated that a company would want to impress financial institutions, creditors, fund managers and prominent businessmen by issuing them well laid-out, coloured copies of their annual reports, [minority] shareholders should not be given second-class treatment and be merely served poor quality black and white copies of the annual reports minus valuable information. In some cases, copies of annual reports sent to shareholders contain only the bare minimum disclosure stipulated by the law whilst those sent or distributed to selected clients of the company contain much more information. There should be fair play in the market. Shareholders are a necessary part of a capitalist system and have the right to expect the same level of information proffered by their companies to other parties.

Overall, accounting in Malaysia before the MIA was activated was in an uncertain and unsatisfactory state. But the situation has not really improved even after the MIA was revived in 1987. Thus, as stated by Nahapiet (1988), whilst accounting change may be mobilised in the pursuit of certain vested interests, once implemented it may shape and be shaped by the belief and expectations of the participants. But this explanation by Nahapiet (1988) may very well be only "part" of the story, for the full "story" is really a little more complicated. As stated by Belkaoui (1974) mentioned earlier, a class elite in many developing countries are interested in maintaining secrecy. In Malaysia, the MIA although it was activated in 1987, is not expected to emerge as a strong and respected accounting body able to play the required role in confronting cases of corruption, nepotism and patron-clientelism that have been present in the country for many decades but particularly in the last few years. And when it concerns the MASB formed a decade after the MIA's revival, it is never in the interest of this elite to have its accounting standards complied by all - regardless of what is stated on paper. In short it is in their interest to see a weak accounting profession and inadequate financial reporting. Therefore, while the MIA council members appear to be ineffective, others with the power to ensure that the accounting profession is made to be strong have not made the necessary moves. And while the MASB may issue one standard after another, the fact that these accounting standards in many cases may not be complied with shall never be of much interest of just about anyone.

In a number of accounting episodes such as the MIA lying low and its later activation, several factors other than ethnicity, foreign investments or strong pragmatic government were noted by those interviewed as being responsible for their occurrence. But this should not perhaps be surprising. Note what was stated by Miles and Huberman (1994, p. 276) earlier. Similar 
point was also developed by Kvale (1996, p. 4) who mentioned:

The aim of the qualitative research interview is not to end up with unequivocal and unquantifiable meanings on the themes in focus. What matters is rather to describe precisely the possibly ambiguous and contradictory meanings expressed by the interviewee. The contradictions of interviewees may not merely be due to faulty communication in the interview situation, nor to their personality structures, but may in fact be adequate reflections of objective contradictions in the world in which they live.

By and large, it may safely be said that the manner that accounting developed over time and space is closely related to particular features of the socio-political and economic context in which it has become institutionalised and developed. Different forms of accounting development can only be understood in terms of the broader social context in which they develop and become institutionalised. Accordingly, how entities are constituted and inter-connected are key questions for any comparative analysis of accounting structure and development and clearly depend on particular features of their societal contexts. The Malaysian accounting story has provided evidence of the character of accounting as a social activity within a specific network of changeable social relations. That is, accounting has been implicated in the broader political struggles in society which may persist across different temporal settings. To be more exact, with the inception of the NEP in 1971 where the government abandoned the relatively laissez-faire approach that had preceded it, accounting in Malaysia does not seem to be of much relevance to just about anyone - except perhaps the foreign investors. The reason for that may be found in the following remark by Miller (1994, p. 29):

The growth and deployment of accounting, that is to say, can be understood in relation to the emergence of particular political systems, and particular ways of seeking to govern the conduct of individuals. For accounting is one of the key ways in which attempts have been made to exert influence on individuals through indirect means. Such modes of government can be regarded as characteristics of liberal democratic societies. In so far as such societies mark out the economy as a distinct sphere with its own laws and regularities, and make the individual a fundamental locus of responsibility, accounting has a central place. Understood as a mode of government of economic life, accounting can be appealed to as a way of seeking to act upon the conduct of individuals to remedy deficits of rationality and responsibility. (Emphasis added.)

It thus may be deduced that as long as racial concern and strong pragmatic government are in the environment surrounding accounting emitting significant influence, and at the same time the powerful elite comprising those in the government, corporate and accounting sectors stays intact, accounting in Malaysia in the coming years just like what has largely been the case to date will continue to develop in a rather haphazard manner. There may of course be (cosmetic) changes taking place here and there. But the fundamental character of accounting in Malaysian society which is not quite liberal nor fully democratic would still be intact. It provides the image of corporate governance for the consumption of foreigners, but in actual effect is hardly to provide more reliable financial reports. It is a mere tool among 
so many others to entice those from overseas to invest into the country. So the more things (appear to) change, the more they stay the same. There is a need thus not to be easily misled by the presence of "changes" taking place in the accounting arena and the false and shallow picture that they provide. Indeed, the so-called changes occurring in the accounting arena in recent time are more ephemeral than real, structural rather than in-depth. They are the result of intrusive events in the form of economic recessions and Vision 2020 which, on the face of the distinctive social, economic and political attributes, have failed to ensure that their occurrence would really make a big difference to the pre-existing arrangement which emerged in the early 1970s with the launching of the NEP. Accounting in Malaysia is clearly influenced by the broader context in which it is embedded.

\section{Bibliography}

Abdul Khalid Sahan (1994) "Globalisation of Capital Markets and the Challenge for Malaysia". Paper presented at Securitisation: The Way to Financial Competitiveness conference, 19-20 September, Kuala Lumpur.

Abdullah Abdul Rahman (1991) "The Malaysia Incorporated Concept: A Key Strategy in Achieving Vision 2020" in the Proceedings for the National Seminar Towards a Developed and Industrialised Society: Understanding the Concept, Implications and Challenges of Vision 2020, 5-7 December, Kuala Lumpur: SERU, Prime Minister's Department.

Abdullah Taib and Mohamed Yusoff Ismail (1982) "The Social Structure" in E.K. Fisk and H. Osman Rani (eds.) The Political Economy of Malaysia, Petaling Jaya: Oxford University Press.

Abraham, C.E.R. (1997) Divide and Rule: The Roots of Race Relations in Malaysia, Kuala Lumpur: Insan.

Abu Hassan Kendut (1986) "Public Accounting and the Accounting Profession in Malaysia". Paper presented at the Universiti Utara Malaysia's Professional Lecture Series, October, UUM.

Adhikari, A. and Tondkar, R.H. (1992) "Environmental Factors Influencing Accounting Disclosure Requirements of Global Stock Exchanges", Journal of International Financial Management and Accounting, 4:2, pp. 75-105.

Aguirre, A. and Hagigi, M. (1987) "Accounting, Economic, and Environmental Determinants of Financial Reporting Practices in Guatemala", International Journal of Accounting, 22, pp. 169-192.

Ahmad Noordin Zakaria (1981) "Proposal for the Establishment of A National Institute of Public Finance and Accountancy", The Malaysian Accountant, 2:1, January, pp. 25-28.

Aliran (1981a) Aliran Speaks: Being a Collection of Aliran's Views on Various Social Issues From August 1977 to September 1981, Penang: Aliran. 
Aliran (1981b) Corruption, Penang: Aliran.

Aliran (1988a) Issues of the Mahathir Years, Penang: Aliran.

Aliran (1988b) Nation on Trial, Penang: Aliran.

Aliran (ed.) (1987) Reflections on the Malaysian Constitution, Penang: Aliran.

AlNajjar, F.K. and Volz, W.H. (1991) "The Status of Accounting and Its Environment in West Germany: An Overview", International Journal of Accounting, 26, pp. 104-117.

Annisette, M.A. (1996) Imperialism and the Professions: A Case Study of the Development of the Institute of Chartered Accountants of Trinidad and Tobago. Unpublished $\mathrm{PhD}$ Thesis, University of Manchester.

Ansari, S.L. and Bell, J. (1991) "Symbolism, Collectivism, and Rationality in Organizational Controls", Accounting, Auditing and Accountability Journal, 4:2, pp. 4-27.

Anuwar Ali (1994) "Industrial Development in Malaysia" in National Institute of Public Administration Malaysia (ed.) Malaysian Development Experience: Changes and Challenges, Kuala Lumpur: INTAN.

Anuwar Ali and H. Osman Rani (1987) "The Malaysian Experience with the MNCs in the Industrial Sector" in Faridah Shahadan and Nor Aini Darus (eds.) Financing for Development: With Special Reference to ASEAN, Singapore: Oxford University Press.

Anuwar Ali and Wong Poh Kam (1993) "Direct Foreign Investment in the Malaysian Industrial Sector" in Jomo K.S. (ed.) Industrialising Malaysia: Policy, Performance, Prospects, London: Routledge.

Armstrong, P. (1985) "Changing Management Control Strategies: The Role of Competition Between Accountancy and Other Organizational Professions", Accounting, Organizations and Society, 10:2, pp. 129-148.

Armstrong, P. (1987) "The Rise of Accounting Controls in British Capitalist Enterprises", Accounting, Organizations and Society, 12:5, pp. 415-436.

Azham Md. Ali (forthcoming) "Accounting in Malaysia in the Post-NEP Era: The Saga Continues".

Azham Md. Ali (2001) "The New Economic Policy and the Accounting Profession in Malaysia: A Case of A Misfit?" Paper presented at School of Accountancy, Universiti Utara Malaysia organised The Second Asian Academic Accounting Association Conference, 17-19 September, Penang, Malaysia.

Bass, J.R. (1973) Malaysian Politics, 1968-1970: Crisis and Response. Unpublished PhD Thesis, University of California, Berkeley.

Berry, A.J., Capps, T., Cooper, D., Ferguson, P., Hopper, T. and Lowe, E.A. (1985) "Management Control in an Area of the NCB: Rationales of Accounting Practices in a Public Enterprises", Accounting, Organizations and Society, 10:1, pp. 3-28. 
Bloom, R. and Naciri, M.A. (1989) "Accounting Standard Setting and Culture: A Comparative Analysis of the United States, Canada, England, West Germany, Australia, New Zealand, Sweden, Japan and Switzerland", International Journal of Accounting, 24, pp. 70-97.

Blumer, H. (1978) "Methodological Principles in Empirical Science" in N.K. Denzin (ed.) Sociological Methods: A Sourcebook, New York: McGraw-Hill.

Boo King Ong (1987) "Market Manipulation and the Securities Industry Act 1983", The Malaysian Accountant, Oct-Dec, pp. 25-31.

Brennan, M. (1985) "Class, Politics and Race in Modern Malaysia" in R. Higgott and R. Robison (eds.) Southeast Asia: Essays in the Political Economy of Structural Change, London: Routledge and Kegan Paul.

Bronfenbrenner, U. (1976) "The Experimental Ecology of Education", Teachers College Record, 78:2, pp. 157-178.

Brown, D. (1994) The State and Ethnic Politics in Southeast Asia, London: Routledge.

Burchell, S., Clubb, C. and Hopwood, A.G. (1985) "Accounting in its Social Context: Towards a History of Value Added in the United Kingdom", Accounting, Organizations and Society, 10:4, pp. 381-413.

Burrell, G. and Morgan, G. (1979) Sociological Paradigms and Organizational Analysis, London: Heinemann.

Bursal, N.I. (1984) "The Accounting Environment and Some Recent Development in Turkey", International Journal of Accounting, 19, pp. 93-128.

Carmony, L. (1987) "Accounting in the Context of its Environment: The Uruguayan Case", International Journal of Accounting, 22, pp. 41-56.

Central Bank (1987) The Role of External Auditors in the Supervision of Financial Institutions in Malaysia, October, Kuala Lumpur: SEACEN.

Chandra Muzaffar (1984) "Has the Communal Situation Worsened Over the Last Decade? Some Preliminary Thoughts" in Syed Husin Ali (ed.) Ethnicity, Class and Development in Malaysia, Kuala Lumpur: Malaysian Science Social Association.

Chandra Muzaffar (1986) Freedom in Fetters: An Analysis of the State of Democracy in Malaysia, Penang: Aliran.

Chandra Muzaffar (1989) Challenges and Choices in Malaysian Politics and Society, Penang: Aliran.

Chandrasekaran Pillay (1974) "Trends in Ethnic Relations" in Yong Mun Cheong (ed.) Trends in Malaysia II: Proceedings and Background Paper, Singapore: Institute of Southeast Asian Studies. 


\section{Macrothink}

Journal of Public Administration and Governance ISSN 2161-7104 2014, Vol. 4, No. 3

Choi, F.D.S. and Mueller, G.G. (1978) An Introduction to Multinational Accounting, Englewood Cliffs: Prentice-Hall, Inc.

Chua, W.F. (1986) "Radical Developments in Accounting Thought", Accounting Review, October, 61:4, pp. 601-632

Collins, M. and Bloom, R. (1991) "The Role of Oral History in Accounting", Accounting, Auditing and Accountability Journal, 4:4, pp. 23-31.

Committee on International Accounting Operation and Education, 1976-78, of the American Accounting Association (1978) Accounting Education and the Third World, Altamonte Springs, Florida: AAA.

Cooper, A.G. (1980) "Problems with the Implementation of International Accounting Standards 1 - 10". Paper presented at the MACPA Make International Accounting Standards Your Business, 8 March, Kuala Lumpur.

Cooper, D. and Sherer, M.J. (1984) "The Value of Corporate Accounting Reports: Arguments for a Political Economy of Accounting", Accounting, Organizations and Society, 9:3/4, pp. 207-232.

Covaleski, M.A. and Dirsmith, M.W. (1990) "Dialectic Tension, Double Reflexivity and the Everyday Accounting Researcher on Using Qualitative Methods", Accounting, Organizations and Society, 15:6, pp. 543-573.

Craig, J. (1988) "Privatisation in Malaysia: Present Trends and Futute Prospects" in P. Cook and C. Kirkpatrick (eds.) Privatisation in Less Developed Countries, London: Harvester Wheatsheaf.

Crouch, H. (1992) "Authoritarian Trends, the UMNO Split and the Limits to State Power" in Joel S. Kahn and Francis Loh Kok Wah (eds.) Fragmented Vision: Culture and Politic in Contemporary Malaysia, North Sydney: Asian Studies Association of Australia and Allen and Unwin.

David Lim (1973) Economic Growth and Development in West Malaysia, Kuala Lumpur: Oxford University Press.

Demirag, I.S. (1993) "Development of Turkish Capitalism and Accounting Regulation in Turkey", Research in Third World Accounting, 2, pp. 97-120.

Dillard, J.F. (1991) "Accounting as a Critical Social Science", Accounting, Auditing and Accountability Journal, 4:1, pp. 8-28.

Douglas, J. (1976) Investigative Social Research, Beverly Hills, CA: Sage.

Edmund Terence Gomez (1990) Politics in Business: UMNO"s Corporate Investments, Petaling Jaya: Forum Enterprise.

Edmund Terence Gomez (1994) Political Business: Corporate Involvement of Malaysian Political Parties, Townsville, Queensland: Centre for South-East Asian Studies, James Cook 
University.

Edmund Terence Gomez (1997) "The Economics and Politics of Privatization in Malaysia", Journal of the Asia Pacific Economy, 2:2, pp. 178-200.

Edwards, C. (1994) "The Role of Foreign Direct Investment" in National Institute of Public Administration Malaysia (ed.) Malaysian Development Experience: Changes and Challenges, Kuala Lumpur: INTAN.

Edwards, C.B. (1975) Protection, Profits and Policy: An Analysis of Industrialisation in Malaysia. Unpublished PhD Thesis, University of East Anglia.

Enthoven, A.J.H. (1973) Accountancy and Economic Development Policy, Amsterdam: North-Holland Publishing Company.

Enthoven, A.J.H. (1977) Accountancy Systems in Third World Economies, Amsterdam: North-Holland Publishing Company.

Filstead, W.J. (ed.) (1970) Qualitative Methodology, Chicago: Markham.

Fisher, C. (1964) Southeast Asia, London: Methuen.

Flanigan, M.A., Tondkar, R.H. and Coffman, E.N. (1994) "The Comparative Development of the Accounting Profession in England, the United States, and Australia: A Sociological Interpretation", Advances in International Accounting, 6, pp. 295-316.

Foo See Liang (1988) The Development of Accounting Systems in Indonesia and Singapore. Unpublished PhD Thesis, University of Hull.

Frankie, W. (1965) "Some Investigations in the Structure, Concepts and Ideals of Chinese Culture" in S.T. Alisjahbana, X.S.T. Nayagam and W. Gungwu (eds.) The Cultural Problems of Malaysia in the Context of Southeast Asia, Kuala Lumpur: The Malaysian Society of Orientalists.

Gale, B. (1985) Politics and Business: A Study of Multi-Purpose Holdings Berhad, Petaling Jaya: Eastern Universities Press.

Goetz, J.P. and LeCompte, M.D. (1984) Ethnography and Qualitative Design in Educational Research, New York: Academic Press.

Goh Cheng Teik (1971) The May Thirteenth Incident and Democracy in Malaysia, Kuala Lumpur: Oxford University Press.

Goh Joon Hai (1970/71) "Recent Legislation on the Profession of Accountancy in Malaysia and Singapore", The Accounting Journal, 1:1, pp. 25-36.

Guba, E.G. (1981) "Criteria for Assessing the Trustworthiness of Naturalistic Inquiries", Educational Communication and Technology Journal, 29, pp. 75-92.

Gul, F. (1983) History and Development of Accounting Education in Malaysia, Singapore: The Regional Institute of Higher Education and Development. 


\section{I Macrothink}

Journal of Public Administration and Governance ISSN 2161-7104 2014, Vol. 4, No. 3

Gullick, J.M. (1981) Malaysia: Economic Expansion and National Unity, Boulder, Colorado: Westview Press.

Hagigi, M. and Williams, P.A. (1993) "Accounting, Economic and Environmental Influences on Financial Reporting Practices in Third World Countries: The Case of Morocco", Research in Third World Accounting, 2, pp. 67-84.

Hammond, T. and Sikka, P. (1996) "Radicalizing Accounting History: The Potential of Oral History", Accounting, Auditing and Accountability Journal, 9:3. pp. 79-97.

Hanifah Noordin (1990) "Ethical Standards in the Accounting Profession". Paper presented at the UUM and Petronas jointly organised Seminar on Management Ethics, 13-14 March, Kuala Lumpur.

Harston, M.E. (1991) A Comparison of the Evolution of Accounting Institutions in Germany and the United States. Unpublished PhD Thesis, University of North Texas.

Hines, R. (1988) "Financial Accounting: In Communicating Reality, We Construct Reality", Accounting, Organizations and Society, 13:3, pp. 251-261.

Hirschman, C. (1971) "Ownership and Control in the Manufacturing Sector of West Malaysia", UMBC Economic Review, 7:1, pp. 20-39.

Ho Kai Leong (1988) Indegenizing the State: The New Economic Policy and the Bumiputera State in Peninsular Malaysia. Unpublished Phd Thesis, Ohio State University.

Hopper, T. and Powell, A. (1985) "Making Sense of Research into the Organizational and Social Aspects of Management Accounting: A Review of its Underlying Assumptions [1]", Journal of Management Studies, September, 22:5, pp. 429-465.

Hopper, T.M., Storey, J. and Willmott, H. (1987) "Accounting for Accounting Towards the Development of a Dialectical View", Accounting, Organizations and Society, 12:5, pp. 437-456.

Hopwood, A.G. (1983) "On Trying to Study Accounting in the Contexts in Which it Operates", Accounting, Organizations and Society, 8:2/3, pp. 287-305.

Hopwood, A.G. (1985) "The Tale of a Committee that Never Reported: Disagreements on Intertwining Accounting with the Social", Accounting, Organizations and Society, 10:3, pp. 361-377.

Hopwood, A.G., Burchell, S. and Clubb, C. (1988) "The Development of Accounting in its International Context: Past Concerns and Emergent Issues", in A.G. Hopwood, (ed.) Accounting from the Outside: The Collected Papers of Anthony G. Hopwood, London: Garland.

Hoskin, K.W. and Macve, R.H. (1986) "Accounting and the Examination: A Genealogy of Disciplinary Power", Accounting, Organizations and Society, 11:2, pp. 105-136. 
Hudack, L.R. (1989) An Exploratory Investigation of Socio-Economic Phenomena that may Influence Accounting Differences in Three Diverse Countries, Unpublished $\mathrm{PhD}$ Thesis, University of North Texas.

Humphrey, C. and Scapens, R.W. (1992) Theories and Case Studies of Organizational Accounting Practices: Limitation or Liberation (Or A Case of Accounting Theory Not Becoming What is Was Not), Working Paper 92/4, University of Manchester, England.

Hung Ai Yun (1984) "Capitalist Development, Class and Race" in Syed Husin Ali (ed.) Ethnicity, Class and Development in Malaysia, Kuala Lumpur: Malaysian Science Social Association.

Ismail Mohd. Salleh (1994) "The Role of Public Sector in the Malaysian Economy" in National Institute of Public Administration Malaysia (ed.) Malaysian Development Experience: Changes and Challenges, Kuala Lumpur: INTAN.

Jesudason, J.V. (1989) Ethnicity and the Economy: The State, Chinese Business, and Multinationals in Malaysia, Singapore: Oxford University Press.

Jesudason, J.V. (1997) "Chinese Business and Ethnic Equilibrium in Malaysia", Development and Change, 28, pp. 119-141.

Johan Saravanamuthu (1987) "The State, Authoritarianism and Industrialization: Reflections on the Malaysian Case", Kajian Malaysia, 5:2, December, pp. 43-75.

Johnson, T.J. and Caygill, M. (1971) "The Development of Accounting Links in the Commonwealth", Accounting and Business Research, Spring, pp. 155-173.

Jomo K.S. (1986) A Question of Class: Capital, the State, and Uneven Development in Malaya, Singapore: Oxford University Press.

Jomo K.S. and Edwards, C. (1993) "Malaysian Industrialisation in Historical Perspective" in Jomo K.S. (ed.) Industrialising Malaysia: Policy, Performance, Prospects, London: Routledge.

Jomo, K.S. (ed.) (1995) Privatizing Malaysia: Rents, Rhetoric, Realities, Oxford: Westview Press.

Junid Saham (1980) British Industrial Investments in Malaysia, 1963-1971, Kuala Lumpur: Oxford University Press.

Kaplan, R.S. (1983) "Measuring Manufacturing Performance: A New Challenge for Managerial Accounting Research", Accounting Review, October, pp. 686-705.

Kaplan, R.S. (1984) "The Evolution of Management Accounting", Accounting Review, July, pp. 390-418.

Kaplan, R.S. (1986) "The Role for Empirical Research in Management Accounting", Accounting, Organizations and Society, 11:4/5, pp. 429-452. 
Keiko Saruwatari (1991) "Malaysia's Localization Policy and its Impact on British-Owned Enterprises", The Developing Economies, December, pp. 371-386.

Kennedy, J. (1993) A History of Malaya, 3rd ed., Kuala Lumpur: S. Abdul Majeed and Co.

Kenzo Horii (1991) "Disintegration of the Colonial Economic Legacies and Social Restructuring in Malaysia", The Developing Economies, December, pp. 281-313.

Khor Kok Peng (1979) Dependence and the Malaysian Economy. Unpublished Master Thesis, Universiti Sains Malaysia.

Khor Kok Peng (1983) The Malaysian Economy, Kuala Lumpur: Marian and Sons (Mal.) Sdn. Bhd.

Kuala Lumpur Stock Exchange (1988) Fact Book, Kuala Lumpur: KLSE.

Kuala Lumpur Stock Exchange and Malaysian Strategic Consultancy Sdn. Bhd. (eds.) (1992) Malaysia The Rising Star: Business and Investment Opportunities and Challenges Towards 2020, Kuala Lumpur: KLSE and MSC Sdn. Bhd.

Kvale, S. (1996) InterViews: An Introduction to Qualitative Research Interviewing, London: Sage.

Laurence K.L. Siaw (1977) "Characteristics of the Ethnic Chinese Community in Malaysia A Sociological Perspective", Jurnal Antropologi dan Sosiologi, 5, pp. 43-52..

Lehman, C. and Tinker, A. (1987) "The 'Real' Cultural Significance of Accounts", Accounting, Organizations and Society, 12:5, pp. 503-522.

Lehman, C.R. (1985) Discourse Analysis and Accounting Literature: Transformation of State Hegemony, 1960-1973. Unpublished PhD Thesis, New York University.

Leigh, M. (1992) "Politics, Bureaucracy, and Business in Malaysia: Realigning the Eternal Triangle" in A.J. MacIntyre and K. Jayasuriya (eds.) The Dynamics of Economic Policy Reform in South-East Asia and the South-West Pacific, Singapore: Oxford University Press.

Lent, J.A. (1984) "Restructuring of Mass Media in Malaysia and Singapore - Pounding in the Coffin Nails?" Bulletin of Concerned Asian Scholars, 16:4, pp. 26-35.

Lim Kit Siang (1978) Time Bombs in Malaysia: Problems of Nation-Building in Malaysia, 2nd ed., Petaling Jaya: Democratic Action Party.

Lim Kit Siang (1982) Malaysia in the Dangerous 80s, Petaling Jaya: Democratic Action Party.

Lim Kit Siang (1986) Malaysia: The Crisis of Identity, Petaling Jaya: Democratic Action Party.

Lim Mah Hui (1981) Ownership and Control of the One Hundred Largest Corporations in Malaysia, Kuala Lumpur: Oxford University Press.

Lim Mah Hui (1983) "The Ownership and Control of Large Corporations in Malaysia: The 
Role of Chinese Businessmen" in Linda Y.C. Lim and L.A. Peter Gosling (eds.) The Chinese in Southeast Asia: Ethnicity and Economic Activity, Vol. I, Singapore: Maruzen Asia.

Lim Mah Hui (1988) "Contradictions in the Development of Malay Capital: State, Accumulation and Legitimation" in J.G. Taylor and A. Turton (eds.) Sociology of 'Developing Societies' Southeast Asia, London: Macmillan Education Ltd.

Limlingan, V.S. (1994) The Visible Hand and the Developing Economy: Essays on Management in Southeast Asia, 2nd ed., Manila: De La Salle University Press.

Lin See Yan (1994) "The Malaysian Economy, 1957-91: An Overview" in National Institute of Public Administration Malaysia (ed.) Malaysian Development Experience: Changes and Challenges, Kuala Lumpur: INTAN.

Lincoln, Y.S. and Guba, E. (1985) Naturalistic Inquiry, Beverly Hills, CA: Sage.

Linderberg, M.M. (1973) Foreign and Domestic Investment in the Pioneer Industry Program, Malaysia 1965-1970, Political, Economic, and Social Impacts. Unpublished PhD Thesis, University of Southern California.

Loft, A. (1986) "Towards a Critical Understanding of Accounting: The Case of Cost Accounting in the U.K., 1914-1925", Accounting, Organizations and Society, 11:2, pp. 137-169.

Mahathir Mohamad (1985) "Whither Malaysia?" in A.J.L. Armour (ed.) Asia and Japan: The Search for Modernization and Identity, London: The Athlone Press.

Mahathir Mohamad (1991) "Malaysia: The Way Forward". Paper presented at the Inaugural Meeting of the Malaysian Business Council, 29 February, Kuala Lumpur which may be found in Kuala Lumpur Stock Exchange and Malaysian Strategic Consultancy Sdn. Bhd. (eds.) (1992) Malaysia The Rising Star: Business and Investment Opportunities and Challenges Towards 2020, Kuala Lumpur: KLSE and MSC Sdn. Bhd.

Mahathir Mohamad (1995) The Malaysian System of Government, Kuala Lumpur: Prime Minister's Office.

Malaysian Institute of Accountants (1991) Who is an Accountant? Kuala Lumpur: MIA.

Mauzy, D.K. (1984) "Malaysia" in D.K. Mauzy (ed.) Politics in the ASEAN States, Kuala Lumpur: Marican \& Sons (Malaysia) Sdn. Bhd.

Meek, G.K. and Saudagaran, S.M. (1990) "A Survey of Research on Financial Reporting in a Transnational Context", Journal of Accounting Literature, 9, pp. 145-182.

Megat Abdul Rahman (1979) "Future of the Accountancy Profession in Malaysia". Paper presented at the MACPA 21st Anniversary seminar, 29 September, Kuala Lumpur.

Megat Abdul Rahman (1980) "The Accountancy Profession in Malaysia - Some Current Issues". Paper presented at the New Approaches and Technologies in Management, 
Universiti Kebangsaan Malaysia, 22 June.

Meilink-Roelofsz, M.A.P. (1962) Asian Trade and European Influences in the Indonesian Archipelago Between 1500 and about 1630, The Hague: Martinus Nijhoff.

Merino, B.D. (1988) "Accounting History: Structure and Methodology" in N.X. Dressel, E.L. Slocum and A.R. Roberts (eds.) Dedication of the Accounting History Research Center Proceedings, The Academy of Accounting Historians.

Miles, M.B. and Huberman, A.M. (1994) Qualitative Data Analysis: An Expanded Sourcebook, 2nd ed., London: Sage.

Miller, P. (1994) "Accounting as Social and Institutional Practice; An Introduction" in A.G. Hopwood and P. Miller (eds.) Accounting as Social and Institutional Practice, Cambridge University Press.

Miller, P. and O'Leary, T. (1987) "Accounting and the Construction of the Governable Person", Accounting, Organizations and Society, 12:3, pp. 235-265.

Mitchell, C.L. (1974) Corporate Financial Reporting in Malaysia, Kuala Lumpur: KLSE.

Mohamed Ariff and Tan Ey Chye (1994) "Trade and Development" in National Institute of Public Administration Malaysia (ed.) Malaysian Development Experience: Changes and Challenges, Kuala Lumpur: INTAN.

Mohd. Ariff Yusof (1993) "Securities Commission: Regulator of the Capital Market". Paper presented at the 9th National Accountants' Conference, 20-21 July. Kuala Lumpur.

Mohd. Salleh Majid (1993) "The Malaysian Capital Market: New Rules of the Game", Capital Markets Review, pp. 1-21.

Mohd. Sheriff Mohd. Kassim (1991), "Vision 2020: Its Linkages with the Sixth Malaysia Plan and the Second Outline Perspective Plan" in the Proceedings for the National Seminar Towards a Developed and Industrialised Society: Understanding the Concept, Implications and Challenges of Vision 2020, 5-7 December, Kuala Lumpur: SERU, Prime Minister's Department.

Mohd. Sheriff Mohd. Kassim (1992) "Economic Outlook and Privatization Trends Towards 2020" in Kuala Lumpur Stock Exchange and Malaysian Strategic Consultancy Sdn. Bhd. (eds.) Malaysia The Rising Star: Business and Investment Opportunities and Challenges Towards 2020, Kuala Lumpur: KLSE and MSC Sdn. Bhd.

Mohd. Taib Osman (ed.) (1985) Malaysian World-View, Singapore: Institute of Southeast Asian Studies.

Morgan, G. (1988) "Accounting as Reality Construction: Towards a New Epistemology for Accounting Practice", Accounting, Organizations and Society, 13:5, pp. 477-485.

Nahapiet, J. (1988) "The Rhetoric and Reality of an Accounting Change: A Study of 
Resource Allocation", Accounting, Organizations and Society, 13:4, pp. 333-358.

Nawawi Mat Awin (1979) Speech delivered at the MACPA 21st Anniversary seminar, 29 September, Kuala Lumpur.

Neher, C.D. (1994) Southeast Asia in the New International Era, 2nd ed. Boulder: Westview Press.

Neuman, W.L. (1991) Social Research Methods: Qualitative And Quantitative Approaches, Boston: Allyn and Bacon.

Nobes, C. (1992) International Classification of Financial Reporting, 2nd ed., London: Routledge.

Nor Mohamed Yakcop (1994) "Mobilising Foreign Capital in the Malaysian Securities Market". Paper presented at Securitisation: The Way to Financial Competitiveness conference, 19-20 September, Kuala Lumpur.

Norma Mahmood (1994) "Malaysia" in Norma Mahmood (ed.) Rethinking Political Development in Southeast Asia, Kuala Lumpur: University of Malaya Press.

Norma Mansur and Ahmad Nordin Zakaria (1990) "Public Accountability - The Malaysian Case" in Faculty of Economics and Administration (ed.) Issues and Challenges for National Development: Selected Papers Presented During the 21 st Anniversary Conference, December 1987, Kuala Lumpur: Faculty of Economics and Administration, University of Malaya.

O'Brien, L. (1993) "Malaysian Manufacturing Sector Linkages" in Jomo K.S. (ed.) Industrialising Malaysia: Policy, Performance, Prospects, London: Routledge.

Oh Chong Peng (1987) "Monitoring Standards". Paper presented at the MIA and MACPA jointly organised 3rd National Accountants Conference, 10-11 September, Kuala Lumpur.

Ozay Mehmet (1986) Development in Malaysia: Poverty, Wealth and Trusteeship, London: Croom Helm.

Parker, R.H. (1989) "Importing and Exporting Accounting: The British Experience" in A.G. Hopwood (ed.) International Pressures for Accounting Change, London: Prentice Hall.

Parker, R.H. (1994) "Context, Diversity and Harmonization" in T.E. Cooke and R.H. Parker (eds.) (1994) Financial Reporting in the West Pacific Rim, London: Routledge.

Parker, W.C., Jr. (1973) Communications and the May 13th Crisis: A Psychocultural Interpretation, Kuala Lumpur: University Malaya Press.

Patrick Pillai and Pauline Almeida (1988) "Accountants: Power, Profits and Politics", Malaysian Business, 16 August, pp. 11-22.

Patton, M.Q., (1990) Qualitative Evaluation and Research Methods, 2nd ed., Newbury Park, CA: Sage.

Perera, H. (1989) "Accounting in Developing Countries: A Case for Localised Uniformity", 
British Accounting Review, 21:2, pp. 141-157.

Phenix, P. (1986) "Directors, Shareholders and Auditors Under the Companies Act 1965 - As Amended", The Malaysian Accountant, April, pp. 7-16.

Pillai, P.N. (1984) Companies and Securities Handbook - Singapore \& Malaysia, Singapore: Butterworths.

Pratt, J. and Behr, G. (1987) "Environmental Factors, Transaction Costs, and External Reporting: A Cross-National Comparison", International Journal of Accounting, 22, pp. 1-24.

Puthucheary, J. (1960) Ownership and Control in the Malayan Economy, Singapore: Eastern Universities Press Ltd.

Puxty, A.G., Willmott, H.C., Cooper, D.J. and Lowe, T. (1987) "Modes of Regulation in Advanced Capitalism: Locating Accountancy in Four Countries", Accounting, Organizations and Society, 12:3, pp. 273-291.

Radebaugh, L.H. (1975) "Environmental Factors Influencing the Development of Accounting Objectives, Standards and Practices in Peru", International Journal of Accounting, Fall, pp. $39-56$.

Radebaugh, L.H. and Gray, S.J. (1993) International Accounting and Multinational Enterprises, 3rd ed., New York: John Wiley and Sons, Inc.

Raja Tan Sri Mohar Raja Badiozaman (1979) "Foreign Investment - The Malaysian Experience", Malaysian Management Review, 13:3, pp. 12-25.

Rajah Rasiah (1993) "Free Trade Zones and Industrial Development in Malaysia" in Jomo K.S. (ed.) Industrialising Malaysia: Policy, Performance, Prospects, London: Routledge.

Ravenhill, J. (1995) "The Ethnic Factor in Development" in J. Ravenhill (ed.) The Political Economy of East Asia: Singapore, Indonesia, Malaysia, The Philippines and Thailand, Vol. II, Edward Edgar Publishing Limited.

Report on the 3rd ASEAN Federation Accountants Conference, 8-11 September, 1982, Bangkok.

Report on the First Forum of Accountants of ASEAN Member Countries, 15-17 September, 1976, Manila.

Rigg, J. (1991) Southeast Asia: A Region in Transition, London: Unwin Hyman. Ltd.

Rohwer, J. (1995) Asia Rising: How History's Biggest Middle Class Will Change the World, Singapore: Butterworth-Heinemann Asia.

Ryan, B., Scapens, R.W. and Theobald, M. (1992) Research Method and Methodology in Finance and Accounting, London: Academic Press.

Salleh Majid (1989) "The Equity Structure of Listed Companies". Paper presented at the Persatuan Sains Sosial Malaysia and Institut Pengajian Tinggi, Universiti Malaya jointly 
organised New Economic Policy and Its Future, 24-26 July, Universiti Malaya.

Samuels, J.M. and Oliga, J.C. (1982) "Accounting Standards in Developing Countries", International Journal of Accounting 17, pp. 69-88.

Samuels, J.M. and Piper, A.G. (1985) International Accounting: A Survey, London: Croom Helm.

Scapens, R.W. (1990) "Researching Management Accounting Practice: The Role of Case Study Methods", British Accounting Review, 22, pp. 259-281.

Schlossstein, S. (1991) Asia's New Little Dragons: The Dynamic Emergence of Indonesia, Thailand and Malaysia, Chicago: Contemporary Books.

Selltiz, C., Wrightsman, L.S. and Cook, S.W. (1976) Research Methods in Social Relations, 3rd ed., New York: Holt, Rinehart and Winston.

Shaari Isa (1990) "Tabling of Accounts at the AGM - Keeping the Deadline", Akauntan Nasional, October, pp. 13-15.

Sieh Mei Ling (1977) "The Managerial Revolution in Malaysia", Malaysian Management Review, 12:1, pp. 40-47.

Sieh Mei Ling (1982) Ownership and Control of Malaysian Manufacturing Corporations, Kuala Lumpur: UMCB Publications.

Simon Tan (1990) "The Rise of State Authoritarianism in Malaysia", Bulletin of Concerned Asian Scholars, 22:3, pp. 32-42.

Simone, V. and Feraru, A.T. (1995) The Asian Pacific: Political and Economic Development in Global Context, New York: Longman.

Smith, A.D. (1976) Social Change, London: Longman Group Ltd.

Smith, C., Whipp, R. and Willmott, H. (1988) "Case Study Research in Accounting: Methodological Breakthrough or Ideological Weapon", Advances in Public Interest Accounting, 2, pp. 95-120.

Stake, R. (1976) Evaluating Educational Programs: The Need and the Response, Washington, DC: OECD Publications Center.

Stephen Hong-Chye Chee (1971) Sociocultural Pluralism and Political Change: The Dilemmas of the Bimodal Society in Malaya. Unpublished PhD Thesis, University of Pittsburgh.

Sterling, R.R. (ed.) (1974) Institutional Issues in Public Accounting, Scholars Book Co.

Strauch, J. (1986) "Multiple Ethnicities in Malaysia: The Shifting Relevance of Alternative Chinese Categories" in B. Gale (ed.) Readings in Malaysian Politics, Petaling Jaya: Pelanduk Publications.

Stubbs, R.S. (1974) Counter-insurgency and the Economic Factor, The Impact of the Korean 
War Prices Boom on the Malayan Emergency, Singapore: Institute of Southeast Asian Studies.

Subimal Sen Gupta (1987) "The Accountancy Profession: Today and Tomorrow". Paper presented at the 21st Anniversary of the Faculty of Economics and Administration, Universiti Malaya, Dec. 15th-16th.

Sumitro Djojohadikusomo (1968/69) Trade and Aid in South-East Asia, Vol. 1: Malaysia and Singapore, Kuala Lumpur: University of Malaya Co-op.

Syed Husin Ali (1965) "A Note on Malay Society and Culture" in S.T. Alisjahbana, X.S.T. Nayagam and W. Gungwu (eds.) The Cultural Problems of Malaysia in the Context of Southeast Asia, Kuala Lumpur: The Malaysian Society of Orientalists.

Syed Husin Ali (1981) The Malays: Their Problems and Future, Kuala Lumpur: Heinemann Asia.

Syed Husin Ali (1984) "Social Relations: The Ethnic and Class Factors" in Syed Husin Ali (ed.) Ethnicity, Class and Development in Malaysia, Kuala Lumpur: Malaysian Science Social Association.

Tan Chee Beng (1987) "Ethnic Relations in Malaysia in Historical and Sociological Perspectives", Kajian Malaysia, 5:1, June, pp. 99-119.

Tan Liong Tong (1992) "Goodwill and Identifiable Intangible Assets: An Empirical Study of Company Practices and User Preferences in Malaysia", The Malaysian Accountant, April, pp. 3-10.

Tan Liong Tong and Chew Tek Ann (1996) "Non-Disclosure in the Abridged Profit and Loss Accounts of Malaysian Listed Corporations", The Malaysian Accountant, April, pp. 2-5.

Tan Liong Tong, Zainal Abidin Kidam and Cheong Pooi Wah (1989) "Information Needs of Users and Voluntary Disclosure Practices of Malaysian Listed Corporations", Paper presented at the International Accounting Seminar on Accounting Trends, Issues and Challenges, 22-24 August, Universiti Pertanian Malaysia.

Tham Seong Chee (1983) Malays and Modernization: A Sociological Interpretation, National Singapore University Press.

Ting Chew Peh (1976) The Chinese in Peninsular Malaysia: A Study of Race Relations in Plural Society. Unpublished PhD Thesis, University of Warwick.

Tinker, A.M. (1980) "Towards a Political Economy of Accounting: An Empirical Illustration of the Cambridge Controversies", Accounting, Organizations and Society, 5:1, pp. 147-160.

Tinker, T., Lehman, C. and Neimark, M. (1991) "Falling Down the Hole in the Middle of the Road: Political Quietism in Corporate Social Reporting", Accounting, Auditing and Accountability Journal, 4:2, pp. 167-200. 


\section{I Macrothink}

Journal of Public Administration and Governance ISSN 2161-7104 2014, Vol. 4, No. 3

Tony Seah (1993) "Challenges and Problems Faced by the Accounting Profession". Paper presented on the occasion of MIA's practising members Dialogue with the MIA's public practice committee, 12 November, Awana Golf and Country Club.

Van Maanen, J. (1979) "Reclaiming Qualitative Methods for Organizational Research: A Preface", Administrative Science Quarterly, 24, pp. 520-526.

van Manen, M. (1977) "Linking Ways of Knowing with Ways of Being Practical", Curriculum Inquiry, 6:3, pp. 205-228.

Viswanathan Selvaratnam (1983) "Intercommunal Relations and Problems of Social-Economic Development: The Malaysian Dilemma" in G. Gunatilleke, N. Tiruchelvam and R. Coomaraswamy (eds.) Ethical Dilemmas of Development in Asia, Lexington: Lexington Books.

von Vorys, K. (1975) Democracy Without Consensus: Communalism and Political Stability in Malaysia, Princeton University Press.

Vreeland, N., Dana. G.B., Hurwitz, G.B., Just, P., Moeller, P.V. and Shinn, R.S. (1976) Area Handbook for Malaysia, 3rd. ed., Washington, D.C.: U.S. Government Printing Office.

Walton, P. (1986) "The Export of British Accounting Legislation to Commonwealth Countries", Accounting and Business Research, Autumn, pp. 353-357.

Wheelwright, E.L. (1963) "Industrialisation in Malaya" in T.H. Silcock and E.K. Fisk (eds.) The Political Economy of Independent Malaya: A Case-Study in Development, Singapore: Eastern Universities Press Ltd.

Wheelwright, E.L. (1965) Industrialization in Malaysia, Melbourne University Press.

Williams, B.C. (1988) A Realist Theory of Auditing. Unpublished PhD Thesis, University of East Anglia.

Willmott, H.C. (1990) "Serving the Public Interest? A Critical Analysis of a Professional Claim" in D. Cooper and T. Hopper (eds.) Critical Accounts, London: Macmillan.

World Bank (1993) The East Asian Miracle: Economic Growth and Public Policy, New York: Oxford University Press.

Yanow, D. (1994) "Interpretive Policy Analysis: Notes Toward a Theory" in J.S. Jun (ed.) Development in Asia Pacific: A Public Policy Perspective, Berlin: Walter de Gruyter and Co.

Yong Hang Chang (1988) A Comparative Study of the Accounting Systems of Five Countries in East and Southeast Asia, Unpublished PhD Thesis, Virginia Polytechnic Institute and State University.

Yoshihara Kunio (1988) The Rise of Ersatz Capitalism in South-East Asia, Singapore: Oxford University Press.

Yoshiyuki Hagiwara (1972) "Political Culture and Communalism in West Malaysia", The Developing Economies, 10:3, Sept., pp. 250-266. 
Zainal Abidin Putih (1986) "A Commentary on Accountability in the Profession" in the Proceedings for the MIA and MACPA jointly organised 5th ASEAN Federation of Accountants Conference, 4-7 November, Kuala Lumpur.

Zainal Aznam Yusof (1994) "Growth and Equity in Malaysia" in National Institute of Public Administration Malaysia (ed.) Malaysian Development Experience: Changes and Challenges, Kuala Lumpur: INTAN.

Zakaria Haji Ahmad (1993) "Malaysia in an Uncertain Mode" in J.W. Morley (ed.) Driven by Growth: Political Change in the Asia-Pacific Region, London: M.E Sharpe.

\section{Annual Reports}

MACPA Annual Reports: 1995, 1994, 1992, 1990, 1989, 1987, 1986, 1985, 1984, 1983, 1982, 1981, 1977,

MIA Report and Accounts: 1995, 1994, 1989, 1967-1987.

Securities Commission Annual Report: 1995.

Central Bank Annual Report: 1963.

\section{Legislations}

Act No. 94, Accountants Act, 1967 and Accountant Rules 1972 (As at 14th July 1984), Kuala Lumpur: Malaysian Law Publishers Sdn. Bhd.

Act No. 94, Accountants Act, 1967 and Rules, 1972 \& Audit Act, 1967 (Act 62) (As at 10th February 1993), Kuala Lumpur: International Law Book Services.

Act No. 125, Companies Act and Companies Regulation (All Amendments up to March 1995), 15th ed., Kuala Lumpur: MDC Publishers Printers Sdn. Bhd.

Act No. 498, Securities Commission Act, 1993 (Up to 10 Apr. 1993), Kuala Lumpur: Internatonal Law Book Services.

Act No. 558, Financial Reporting Act 1997, Kuala Lumpur: Percetakan Nasional Malaysia Berhad.

Official Documents (unless stated otherwise they are issued by the Government of Malaysia) Malayan Constitutional Documents 1960.

The First Outline Perspective Plan, 1970-1990.

The Malaysian Plans: Third (1976-80), Fifth (1986-1990), Sixth (1990-95), Seventh (1996-2000).

The May 13 Tragedy: A Report by the National Operations Council dated 9 October 1969.

The Mid-Term Review of the Second Malaysian Plan. 
The Second Outline Perspective Plan, 1991-2000.

\section{Endnotes:}

iSee Burrell and Morgan (1979) for more who in coming out with these four mutually exclusive research paradigms create a dichotomy between the subjective and objective approaches. Hopper and Powell (1985) disagree with the dichotomy and view subjective-objective dimension as a continuous with radical humanist and radical structuralist combined to create the radical paradigm.

${ }^{i i}$ For the excellent discussion of the relationship between race and class in Malaysia, see Brennan (1985), Hung Ai Yun (1984), Syed Husin Ali (1984) and Yoshiyuki Hagiwara (1972).

iii As defined by Khor Kok Peng (1979, p. 193) to be the ratio between net fixed investment and net profits.

${ }^{\text {iv }}$ This meant that local companies of not only ploughing back all their profits for further productive activity, but also borrowing an equivalent amount to invest (Jomo, 1986, p. 241, footnote 20).

${ }^{\mathrm{v}}$ This took place when it became evident that the domestic market was limited by the fact of the nation's small population and relatively low average income and that such strategy did not generate sufficient employment opportunities to absorb an ever growing work force. In addition, there was a tendency for industrial capital to prefer already developed areas. In short, the strategy produced disappointing results (Jomo, 1986, p. 222).

${ }^{\mathrm{vi}}$ This fall in the share had however not been consistent across all sectors, for there had been increases in foreign ownership in 1987 compared to 1970 in the case of mining (particularly in crude oil) and construction (Edwards, 1994, p. 688).

${ }^{\text {vii }}$ Sedition Act was first enacted by the British in 1948 to fight the communists.

viiiThe Act superseded the Printing Press Act of 1948 put forward by the British which was later strengthen by its 1971 amendments.

${ }^{\mathrm{ix}}$ So, it is a mix economy that may be found in Malaysia - just like in the case of many other developing countries. The same could perhaps be said about the developed countries for in practice the economic system contains a varying degree of private and public sector involvement.

${ }^{\mathrm{x}}$ Note that the interview quotes are rendered in the present work in a written style following Kvale (1996, p. 267). The use of individual quotes deriving from the interviews and various documents to enrich the analysis may allow the possibility that meanings may be ascribed to words out of their context. This however appears unavoidable in the process of abstraction for such interpretive work. Rest assured, however, that a triangulation strategy is utilised to ensure that only quotes supported by other interviewees and/or documents have been chosen. Those which are not supported by other sources of evidence are still presented in some cases in this work when they are considered plausible.

${ }^{\mathrm{x}} \mathrm{He}$ was among the first few Bumiputra sent to Australia under the Colombo Plan to do accounting (Business Times, 17 Aug. 1989). He qualified as chartered accountant in 1960 after five years with Price Waterhouse in Melbourne. Upon his retirement in 1989, he took over the business of the audit firm Baharom-Jasani. In 1991, it was reported (The Star, 10 July 1991) that Shamsir Jasani \& Co, the seventh largest accounting firm in the country, had 130 staff and was backed by Grant Thornton International.

${ }^{x i i}$ There are three categories of membership of the MIA. The public and registered members are those with accounting bachelor or post-graduate diploma degrees from local higher institutions or accounting professional qualifications from MIA's recognised local and overseas accounting bodies. To become a member, he or she also needed to have three to five years relevant experience in public accounting firms for public accountants and in commerce/industry/public sector entity for registered accountants. (Five years are the rule. But it will be shortened to four years for those with High School Certificate and to three years for those graduating with degrees or diploma from local higher institutions.) The recognised accounting 
bodies (as listed in the Accountants Act's First Schedule) are the Chartered Institutes of Scotland, England and Wales, Ireland, Australia, Canada and India; the Societies of Accountants of Australia and New Zealand; the Association of Certified Accountants (UK); the Institute of Cost and Management Accountants (UK); and Malaysian Association of Certified Public Accountants (MACPA). As for the licensed accountants, they do not have MIA recognised accounting qualifications but are allowed to practice for either one of the following two reasons: they are already in operation as accountants, tax-consultants or tax advisers prior to the passing of the Accountants Act in 1967; the finance minister has granted them limited approval to act as company auditor under Section 8(6) of the Companies Act 1965.

xiii The Act however with regard to a tax consultant or a tax adviser has a provision allowing him or her to practice or hold him/herself out as one when he or she has the authority to do so as granted by any other law that is enforced within the country.

${ }^{\text {xiv }}$ See Johnson and Caygill (1971, p. 167) for more.

${ }^{\mathrm{xv}}$ Some sort of assistance by the ICAEW appears to have also taken place in the early 1980s. See the MACPA 1981 (p. 17) and the 1982 (p. 17) Annual Reports.

${ }^{x v i}$ It may be said that the policy had been forced upon the nation's leaders then. Limlingan (1994, pp. 95-96) notes the "promises" extracted by the British from the nation's leaders (as the prerequisite for the former's willingness to transfer power) include among others the continuance of an economic policy of free enterprise which meant the non-nationalisation of British-owned companies. It also did not help to have the World Bank in its report published in 1955 (which provided comprehensive recommendations to be followed by the newly-elected government for post-colonial economic development) to stress that there should not be any state enterprises or economic nationalism (Jomo, 1986, p. 221).

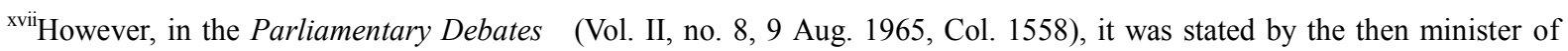
commerce and industry, Dr. Lim Swee Aun, that the committee with the responsibility to draft the Companies Bill (whose chairman came from the ministry of commerce and industry and with the assistance of John Finemore, a Colombo Plan draftsman from Australia) had considered not only the present legislation in force in the UK, Australia, India and New Zealand, but also the draft code prepared for Ghana by Professor Gower and the reports presented in the UK by the committees chaired by Lord Cohen and Lord Jenkin.

xviii In the Federation of Malaya, company law was governed by the Companies Ordinance 1946, whilst in the State of Singapore, it was governed by the Straits Settlements Ordinance 1940. The Sarawak Companies Ordinance was similar to the North Borneo Companies Ordinance, which was based on Hong Kong companies legislation which in turn was modelled from the English Companies Act of 1929.

${ }^{x i x}$ Unfortunately, however, the MIA's registeration function was not executed successfully. In other words, there were those fully qualified to register with the MIA who had failed to do so. Thus, just a few months after MIA was made active in 1987, it was found that as of 29 February, 1988, of the country's 6000 or so qualified accountants only 4453 had registered themselves with the MIA (NST, 20 March 1988). The reminder who did not register were comprised of 600 members of the MACPA, 800 of the CACA and 200 accounting graduates from local universities.

${ }^{x x}$ As a matter of fact, in the case of the UM graduates, it was in 1973 that the MIA recognised their Bachelor of Economics (Accounting). This took place when they also held the post-graduate diploma in accounting programme (Gul, 1983, p. 14). The latter was introduced with the aid of the Canadian Government through the provision of faculty from Canada (The Accounting Journal, 1977, p. 1). To be more exact, the post-graduate diploma was recognised by the MIA on 15 June 1973 allowing its holders with a three-year experience in accounting to enter the government's accounting service. The MACPA however had failed to fully recognise the programme that was discontinued in 1980.

${ }^{x x i}$ This may be seen on the subjects of among others MAS 6 Accounting for Goodwill (see Appendix 3), the setting up of the MASB and the inspection of audit working papers by the ROC (discussed in the text).

${ }^{x x i i}$ Note however that The Malaysian Accountant (July 1981, p. 6) reported the remarks made by none other than then 
MACPA president himself of the "failure" of Streams II and III.

xxiii One of those who mentioned this reason was one of the leaders of the MACPA. Following that answer he was asked that if such was the case why in the world the Accountants Act was passed in the first place? His answer which was not at all believable was that the Act was around "in case there was a necessity" to have it put into implementation later on!

${ }^{\text {xxiv }}$ There is a similarity of this particular fact concerning Malaysia to that describe by Annisette (1996) in the case of the accounting profession in Trinidad and Tobago. Annisette mentioned that the situation in Trinidad and Tobago had led to the case of professional training and credentialing of accountants in the country rested largely in the hands of overseas professional accountancy bodies, particularly the UK-based Chartered Association of Certified Accountants.

${ }^{\mathrm{xxv}}$ Hereafter referred to as CACA (MC).

${ }^{x x v i}$ From the reading of the Accountants Act 1967 it appeared that the MIA council then was acting against the Accountants Act. The Second Schedule of the Accountants Act 1967 mentions the following in its Paragraph 8, part 2 under the heading "General Meeting": "The Council shall hold a general meeting of the Institute within six weeks of the receipt of a written request to do so, specifying the objects of the meeting signed by not less than twenty-five members entitled to vote."

${ }^{x x v i i}$ Note however that the MACPA appeared to say that the merger discussion only began sometime during 1976 . See the MACPA 1976 Annual Report (p. 8). Perhaps the discrepancy in date when the merger talks actually began should not surprise anyone. The discrepancy on accounts of for example what have taken place or who were involved are found in many other cases during interviews and also from various documented sources chosen to be analysed.

xxviii It seemed this statement is hard to deny for the MACPA itself which had been conducting exams since 1963 was only able to produce 134 accountants or merely 11.1 percent of the total members of the MACPA of 1,203 by 1980 . Three foreign bodies had actually more members in the MACPA than what the MACPA could produce on its own. These were the Australian Society of Accountants (ASA), ICAEW and Institute of Chartered Accountants of Australia (ICAA), which had, respectively, 381, 366 and 176 members in the MACPA, accounting together for 76.7 percent of the total number of MACPA members of 1,203 .

${ }^{x x i x}$ This ruling was later reversed in 1989. From I January, 1989, the MACPA grants exemption to accountants who are members of certain recognised professional accounting bodies from its Taxation II and Law II papers (Business Times, 5 Aug. 1989). The members of these bodies are however required to attend an interview and must have at least five years working experience in Malaysia after being qualified as full members of the foreign accounting bodies. It may be said however that much damaged had already been done by the time the ruling was reversed. In particular, as noted by the MIA president, many accountants who were members of CACA and CIMA did not apply for admission to be members of the MACPA "because of certain entry requirements" (Hanifah Noordin, 1990, p. 2). Later when the government gave a nod for the activation of the MIA they were among the people who pushed their way to helm the MIA at the expense of the MACPA people. They were the "new forces" versus that of the "old boys" from the big audit firms who were in control of the "elitist" MACPA. These were the terms used by Pauline Almeida in her excellent piece of writing in the Malaysian Business (16 Aug. 1988, p. 18) on Malaysian auditors.

${ }^{\mathrm{xx}}$ The page number is not stated because the journal for this 1974/75 issue had failed to print numbers on its pages.

${ }^{\mathrm{xxxi}} \mathrm{A}$ year after this letter was published, the then MACPA president was quoted as rejecting the accusation made by members of the general public that there was discrimination committed by CPA firms' non-Malay partners in not taking Bumiputra article students, contributing to the problem of very low proportion of Bumiputra CPAs (Business Times, 5 Aug. 1989): "Accounting firms do not limit the number of Bumiputra students in their organisations but the number of Bumiputra students staying for long is small." He also stressed that there was a problem in attracting Malay students from rural areas to join articleship due to the fact that they normally did not have the basic qualifications needed to enter the training scheme.

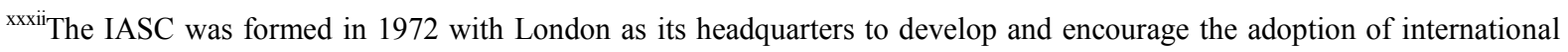
accounting standards that concern the form and content of disclosure in financial statements. The IASC consists of 
representatives from professional accounting bodies from North America (3), Europe (4), Japan and Australia.

${ }^{\text {xxxiii }}$ To be more exact, the government targets included that within the span of two decades, the incidence of poverty in the peninsula should be reduced from 49.3 percent to 16.7 percent and that the ownership of share capital in the corporate sector should be restructured such that the share of Malays and other Bumiputra ("sons of the soil") (54 percent of the population in 1970) would increase from 2.4 percent to at least 30 percent while that of other Malaysians, from 34.3 percent to 40 percent by 1990 . Foreign holdings were targeted to fall from about 63.4 percent to 30 percent. Thus, Malaysians were to account for 70 percent of total share capital within the corporate sector. Although the foreign share was expected to decline from 61 percent in 1970 to 30 percent in 1990, the volume of shares held by foreign interests was projected to be about five times more in 1990 than in 1970 (Vreeland et al., 1976, p. 295).

${ }^{\text {xxiv }}$ The excessive speculation in the then Malayan Stock Exchange (formed through the efforts of the Central Bank and a group of brokers who were members of the Malayan Stockbrokers Association in 1960) was duly noted in the Central Bank 1963 Annual Report. And even when the Securities Industry Act, 1973 (SIA) was enacted to provide the government with powers to curb various forms of market manipulation, it was not brought into force until 1976. Unfortunately, it appears that its enforcement did not result in anything new in the way the market was treated by investors and even their own regulators. As noted by Boo King Ong (1987, p. 26): "The Malaysian experience has so far been one of wide and sudden fluctuations in prices. Allegations of market-rigging and manipulation and other forms of securities frauds, failure by the KLSE both to maintain an orderly market and to instil confidence in both the investors and the government that it is an effective regulatory body, and a situation where members of the regulatory body, that is, the KLSE's committee, have themselves been disciplined by the Registrar instead of their disciplining errant members."

${ }^{x x x v}$ Note that Chandra Muzaffar and Aliran appear to be well versed in this subject matter. Check for example Aliran (1981a, Chapter Three), Aliran (1981b), Aliran (1988a, Chapter Four) and Chandra Muzaffar (1989, pp. 47-56). For more on the same subject, please check also the following: The speeches made by Lim Kit Siang on 25 October 1977,27 October 1975 and 14 July 1971 which appear in Lim Kit Siang (1978); the section entitled "On a Clean, Efficient and Democratic Government" in Lim Kit Siang (1986); and finally Schlossstein (1991, Chapter Four).

${ }^{\text {xxxi }}$ The support did not arrive, but that did not stop the MACPA leaders trying to find ways to ensure that the MIA and the MACPA would at the end be integrated. Thus, the then MACPA president in 1987 mentioned (The Malaysian Accountant, July 1987, p. 3): "The Council has recently announced that arrangements have been finalised and put into effect for cooperation between the Association and the Malaysian Institute of Accountants in order to work towards the final objective, an objective that the Association has pursued for more than ten years - that of a Single National Body of Accountants." He next announced that in order to achieve this objective the Association and the MIA had agreed that the "previous cooperation" that existed between the two bodies should be enhanced through the joint cooperation of most of the committees of the two bodies.

xxxvii Please note however that in subsequent interview a few weeks later this person changed this story of his to that of "personal" reasons to be the basis for the MIA to be activated in 1987. One of the personal reasons concerned the presence of so many accountants then who could not get into the MACPA but who were still hoping to be members of an active national accounting body at the local level. The MIA found languishing by these people were found to be a good vehicle to do it. Why did he change the story? Probably because the old one brought bad light to the MACPA.

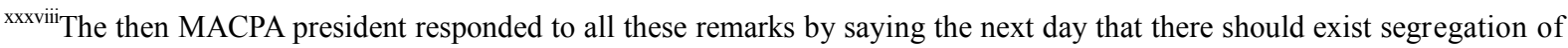
duties between the MACPA and the MIA in the arena of accounting practice/profession in the country (The Star, 13 Oct. 1988). He also said that the MIA and MACPA were not currently working for merger but that did not mean that the two bodies could not hope for "unification" through close co-operation. He pointed out that there should not be any duplication of resources or the case where "... one party tried to impose a 'one-voice' system in the profession."

${ }^{\mathrm{xxxix}}$ That of the equity requirements on investment in most business enterprises: 30 percent equity in a business enterprise for 
Bumiputra, 40 percent for other Malaysians and 30 percent foreigners.

${ }^{\mathrm{xl}}$ It appears that all these efforts had borne fruits. While the net inflow of FDI into Malaysia averaged RM 200-RM 300 million annually from the 1960s to the early 1970s and hovered around RM 1 billion annually during the period 1974-79 before rising to a record level of RM 3.3 billion in 1982, since 1987 the amount of FDI has shot up tremendously: it was RM 1.1 billion in 1987, RM 1.9 billion in 1988, RM 6.8 billion in 1990 and RM 9.5 billion in 1991 (Lin See Yan, 1994, p. 569). In particular, private investment in the manufacturing sector grew at an average rate of 50 percent per year between 1987 and 1990. There was a three fold increase in three years of investment in the manufacturing sector with approved projects totalling RM 9.1 billion in 1988 increasing to RM 28.1 billion in 1990. Over the 1980-88 period, manufacturing goods' share of the nation's total exports grew from 22 percent to 49 percent. In 1990, the export of manufactures accounted for 60.4 percent of total exports while the export of agricultural commodities accounted for only 10 percent (Anuwar Ali, 1994, p. 710).

xli The new developments included the followings: the corporatisation of the stockbroking members of the KLSE, the installation of real-time price reporting system for brokers (MASA), the forming of Advance Warning and Surveillance Unit (AWAS), the launching of the Second Board, the introduction of semi-automated trading system called System on Computerised Order Routing and Execution (SCORE) to replace that of the open-outcry, the implementation of Fixed Delivery and Settlement System (FDSS) to make clearing and settlement more efficient, the raising to RM 20 million as the minimum capital requirements for all stockbroking companies, the issuance of new listing manual containing a new section of corporate disclosure policies and penalties, the delisting of all Malaysian companies from the Stock Exchange of Singapore and last but certainly not the least the granting of permission for the listing of property trust, warrants and TSR in the KLSE. It appears that all these and other related strategies had helped in ensuring the KLSE to grow by leaps and bound in the late 1980s (Kuala Lumpur Stock Exchange and Malaysian Strategic Consultancy Sdn. Bhd., 1992, pp. 28-29): from 1980 to 1989, the 250 companies listed in 1980 increased to 307 in 1989, and the nominal value and market capitalisation grew to RM 34.3 billion and RM 156.1 billion, respectively; also, the volume of transactions rose from 1.5 billion units in 1980 to 10.2 billion units in 1989, while value increased from RM 5.6 billion to RM 18.5 billion in 1989; by the end of 1989, a record RM 10.7 billion had been raised from the market, the largest amount coming from rights issues, at RM 6.1 billion.

${ }^{x l i i}$ As late as 1987, companies which submitted accounts late were not fined while appeals for extensions to submit accounts or to hold annual general meetings were usually granted. This was because the ROC had only two choices: either to approve the extension of time or to take the responsible party to court (Akauntan Nasional, Oct. 1988, p. 16). In the NST (20 Aug. 1988), the then trade and industry minister said that the latter was not executed for it involved a lot of work. However, with the amendments to the Companies Act 1965 which came into effect on 1 February, 1987, the Registrar had now been empowered to impose compound fines on those who failed to table their accounts at the company's AGM within six months of the balance sheet date. Thus, in July and August 1988, only 43 out of almost 6,000 applications for extensions of the presentation of accounts to shareholders at the AGM were approved. In 1988 total fines of nearly RM 5.5 million were collected. In 1989, it was over RM 4 million - a reduction in amount compared to the previous year due to the temporary lowering of the compound rate (Shaari Isa, 1990, p. 13). These compared to less than RM 300,000 in 1987 (Business Times, 20 Aug. 1988). In the 1990s, the amount of fines collected have continued to go up.

xliii Like the ROC, the IRB also appears to come fully to life in the late 1980s. The director-general of IRB had issued in 1988 an "Advance Notice for Submission of Income Tax Returns for Year Assessment 1989" where it was stated that for all accounts prepared they needed to be accompanied by confirmation letters from qualified accountants and tax agents (The Star, 21 Jan. 1989). Such demand ensured that the unregistered accountants would fail to fulfil it. The IRD would also implement for the "first time" Sections 82 and 114 of the Income Tax Act 1967 in 1989 (NST, 25 Sept. 1988). Three days later the NST (28 Sept. 1988) came out with two news stories showing that the IRB until now had not exactly been quite 
awake: The first was that some 142,000 private limited companies had no income tax records. The then IRB deputy director-general mentioned that the IRB had only 57,000 files on private limited companies although there were 199,000 companies registered with the ROC. The second was on the level of tax compliance in the country that was very low: 60 percent of the revenue in West Germany and the UK comes from income tax; 55 percent in Japan, 50 percent in South Korea and 45 percent in Singapore. But in Malaysia the figure was only 22.3 percent. The following month, in a related and an interesting report published by the Akauntan Nasional (Oct. 1988, p. 19), it was mentioned that with the enforcement of Sections 82 and 114 of the Income Tax Act 1967 in 1989, any businessmen who failed to provide true and complete records of accounting would incur penalties that could go up to RM 10,000 or three years in prison or both. In addition, accountants who assisted their clients to falsify the accounting records would face the same consequence.

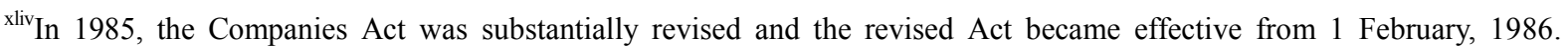
Related to financial reporting in particular, extensive changes were made to the existing Ninth Schedule to incorporate those elements that are regarded as best accounting standards and practices leading towards a much higher disclosure level than previously. For example, companies now are required to prepare a funds statement (statement of changes in financial position) together with the income statements and balance sheets that the auditors have to report on. In regard to the annual company audit, the 1985 amendment requires for the first time all public accounting firms and the individual partners of such firms to register with the Registrar of Companies. Each partner is allocated a number that must be cited in all audit reports. The amendment also increases the range of persons excluded from acting as auditor. It appears that the purpose of this provision is to catch company secretaries operating as auditors (Phenix, 1986, p. 12). The term of an audit license is also reduced from three to two years and the procedure of granting licenses overhauled to make it a more effective method of monitoring and policing standards of auditing. Furthermore, an auditor is required to report to the ROC if he or she were to find that there has been a breach or non-observance of any provisions of the Act. The onus is on the auditor to justify why he has not reported a breach of the Act to the Registrar. This seems to be a major break with the tradition in Malaysian Company Law based as it is on the British system, although it is contained in the corresponding sections of the Australian and Singaporean Acts. Failure to report could result in a requirement for the auditor to justify in a court of law his or her opinion that the breaches have been otherwise adequately dealt with by either one of these two approaches: by a comment about such matter in his or her audit report or by bringing the matter to the attention of the company directors. Section 174(8) of the Act also makes it clear that the auditor making the report would be protected by the law.

${ }^{x l v}$ In the run up to the election, remarks were also thrown from one side to the other. Among the interesting ones were these: In the NST (11 Dec. 1993), the "reformers" had among others mentioned that "... there was a need for the MIA council to be more fairly represented by all recognised accounting organisations, institutions and professionals in the country." In response to this and other related remarks, the MIA vice-president, Soon Kwai Choy, was reported to say in The Star (15 Dec. 1993) that the MACPA "... should accept its subordinate role within the Malaysian Institute of Accountants." He also claimed that the MACPA could not live with the fact that a new era had emerged in the nation's accounting profession when the then MIA leadership was elected by the members to lead the body. He was also quoted to say: "We are elected as MIA members first and foremost. We do not subscribe to sectoral, parochial and elitist policies of certain people who are using MACPA for their own vested interests." He also claimed that "[t]he influential minority is using some of the big firms to champion their cause."

${ }^{x l v i}$ In regard to the one involving the ROC, what happened was that Section 132A of the Companies Act 1965, as a result of the Companies Amendment Act 1992, included the MACPA together with the MIA and MAICSA as the bodies whose members were recognised to be among those who were automatically qualified to act as companies' secretaries and who thus needed not to be given licenses by the ROC (Business Times, 11 Feb. 1993). The inclusion of the MACPA was not to the liking of the MIA president who then urged the ROC to "reconsider" the status of the MACPA to avoid "conflicts" in the implementation of the Companies Act and the Accountants Act 1967 (Business Times, 11 Feb. 1993). He claimed that by 
gazetting the MACPA the ROC had incurred "grave consequences" for the MIA since it undermined MIA's ability to carry out its functions as the only national body enshrined by the Accountants Act to unify and regulate the accountancy profession. The then Company Registrar, Zainon Ali, in response mentioned that the ROC had the right to decide whether any party was "fit and proper" to act as a company secretary and that it was "improper" for any party to question the ROC's decision (Business Times, 13 Feb. 1992).

xlvii This rivalry episode that led to the involvement of the finance ministry to stop the accounting bodies to have their problem settled in court revolved upon the use of statutory designation of either "PA" for public accountants or "LA" for licensed accountants by MIA members in describing their firms. There is an additional provision under the By-Laws - in cases where members in public practice needed to sign any reports or other documents - where a member may have other designatory letters indicating membership to other recognised accounting bodies or accounting degrees after his or her name as long as the statutory designation letters are used in precedence to the other designatory letters (Akauntan Nasional, Feb. 1992, p. 20). This additional provision appears for some reasons not to have come to the knowledge of the MACPA leaders. In early 1992, they claimed that MACPA members should not be denied the right to use the CPA designation that they had earned through hard work (The Malaysian Accountant, Feb. 1992, p. 15). The MACPA official journal, The Malaysian Accountant (Feb. 1992, p. 15), also stated: "The amendment to MIA's By-law 6, if implemented, will effectively prevent members from using the designation 'Certified Public Accountant' after their names, to describe their firms or to describe themselves when signing any reports or other documents in their professional capacity. The implications for members, registered students and the Association's position as a professional body are, therefore, significant." Later that year in a speech that was littered with remarks to embarrass the MACPA in front of leaders of accounting profession from many parts of the world and where among the audience were the country's then King and Queen, the MIA president mentioned that "some people" must have felt that ".... their eminence must be achieved through differentiation" (Akauntan Nasional, Aug. 1992, p. 26).

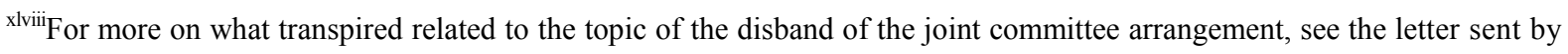
the MIA president dated 5 October, 1987 and the reply by the then MACPA president, Subimal Sen Gupta dated 30 October, 1987 that are placed as Appendices 1 and 2, respectively, in the "MIA 1988 Bounded Document".

${ }^{\text {xlix }}$ For the first MIA council election in 1987, the CACA had certainly tried its best to win more than a few seats. It did that by being better organised than other groups in facing the election. Among others, the CACA had been sending circulars to its members about the elections, and had even a room at the AGM venue where its members could gather, and presumably be briefed about what they were supposed to do (Business Times, 21 Sept. 1987). The CACA was also very much helped by the fact that it had a large number of members who were members of the MIA. In fact, in 1988, the CACA had more members $(1,800)$ and students (about 6,000) in Malaysia than in any other country - except for Hong Kong (Business Times, 2 March 1988). Internationally, the association had then 30,000 members with over 10,000 were based outside the UK and more than 70,000 students. In 1995, the CACA in Malaysia had 12,000 registered students and about 2,000 members (Business Times, 22 May 1995).

${ }^{1}$ Such a rule was certainly in operation as far as the MACPA was concerned. It came in the form of the new admission ruling mentioned earlier.

${ }^{l}$ The fact that this activity by the ROC which has never been conducted before happened to coincide with the efforts conducted by yours truly (to interview personalities such as the then finance minister and the companies' registrar) had led yours truly to conclude that there was more to this action of the ROC than what meets the eye. At any rate, in early 1997, the Business Times (21 Feb. 1997) reported that a total of 67 complaints were received by the ROC in 1996 from the public, particularly from investors who were in doubt as to the validity of various company accounts and that the ROC itself in 1996 had made 300 queries regarding discrepancies in company accounts. It also said that the ROC had now begun a nationwide operation involving ten ROC accountants that would only complete at the end of the year. The operation entailed the 
ROC team "calling on" 1,074 ROC-registered audit firms with whom 1,493 licensed auditors were attached. It also said that auditors found guilty by the ROC would have to pay compound fines or be charged in court and possibly even have their licenses revoked. But note that a few months after the ROC had started to embark on the nationwide inspection of the audit work, the domestic trade and consumer affairs minister came out to say that there were five cases of auditors obstructing the ROC officers in conducting their inspection which to that date numbered to 123 audit firms (NST, 8 July 1997). He also mentioned that the southern branch of the MIA had sent out circulars asking its members not to co-operate with the ROC should their firms be called for inspection. So, he reminded the auditors to co-operate with the ROC or face legal action.

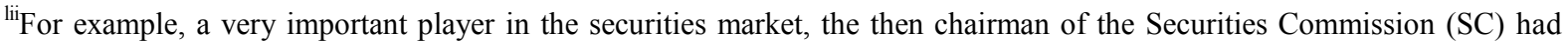
mentioned in his hard-hitting lecture on Malaysia's corporate governance as to his views on the work performance delivered by local auditors (The Malaysian Accountant, Oct/Dec 1993, p. 15). Stating early on that he was uncertain whether the accounting bodies should be self-regulatory in nature, he stressed that the auditors in the country had much room for improvement. He also mentioned that "[t]here have been a number of weaknesses in the performance of the audit function which I do not propose to dwell at length here" (p.15). He said in no uncertain term as follows (p.15): "The health, growth and development of the securities industry is, therefore, related to how well auditors perform their task .... Of course, it is primarily the directors' responsibility to ensure the integrity of the accounts, but let us not thereby marginalise the role of auditors. Otherwise we might as well not have the accounts audited." For other examples, see remarks made by Tun Daim Zainuddin, the finance minister in 1989 (Akauntan Nasional, Sept. 1989, pp. 21-23) and 1990 (Akauntan Nasional, Aug. 1990, p. 26), (Akauntan Nasional, Oct. 1990, pp. 20-21) and those by Tun Ismail Ali, the former Governor of the Central Bank and the chairman of the Bumiputra trust agency, Permodalan Nasional Berhad (PNB) and several listed companies, in 1988 (The Malaysian Accountant, July-Sept 1988, p. 18). Note that the PNB in 1988 had investments in 153 companies where 94 of them were listed at the KLSE (The Malaysian Accountant, July-Sept. 1988, p. 20).

liiiIn the MIA 1994 Annual Report (p. 8), it was revealed that public hearings and fora had now been decided to be put into place. The annual report also noted that copies of the standard would from now on be sent to interested parties such as Federation of Public Listed Companies (FPLC), Federation of Malaysian Manufacturers (FMM) and SC in order to ensure that prior to the adoption of the standard by the MIA any issues raised could be dealt with. Later in the MIA 1995 Annual Report (pp. 12, 18, 20), it was disclosed that a public hearing was conducted (for the first time) in 1995 and that the MIA had organised public discussion on the issues of "financial management and accounting" and "professional conduct and ethics".

${ }^{\text {liv }}$ As early as 1987, the then MACPA president mentioned the need for Malaysia to have an accounting standard-setting body like the one in the United States (Subimal Sen Gupta, 1987). He said (p. 8): “A single standard-setting body similar to the Financial Accounting Standards Board (FASB) in the US may be set up as an independent body with the sole authority to develop and issue approved accounting standards for Malaysia which will be binding on all persons responsible for the accounts." He suggested that the board should be made up of representatives from the profession, the relevant government authorities, the stock exchange, educational institutions and other professional bodies whose work were affected by accounting standards. In the same year, Oh Chong Peng (1987, p. 12) who later became the MACPA president had also made similar remarks. In the following year in July, the then MACPA president gave a press briefing on the formation of an "accounting standards consultative committee" which as mentioned earlier caused much consternation in the MIA council (NST, 23 July 1988). The then MACPA president without discussing the matter beforehand with the MIA leaders stated that the MACPA would initiate the formation of such entity to develop and issue accounting standards and auditing practices in Malaysia. The committee would have representations from MACPA, the MIA, universities and the relevant regulatory authorities.

${ }^{\mathrm{lv}}$ Vision 2020 is supported in the short term by two instruments of national planning: the Second Outline Perspective Plan (OPP2) which covers a ten-year period beginning 1990 and ending in the year 2000 and the five-year development plans (see Mohd. Sheriff Mohd. Kassim, 1991). The latter are comprised of the Sixth (1990-95) and Seventh (1996-2000) Malaysian 
Plans. The OPP2 embodied the National Development Policy (NDP) introduced with the end of OPP1, itself premised on the NEP. The NDP taking off from NEP is expected to ensure that through the continuing application of the philosophy of growth with equity, by the year 2020, there would be almost a complete eradication of poverty and a distribution of wealth to closely reflect the population structure.

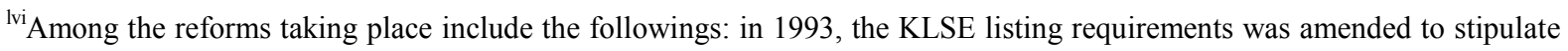
that companies seeking listing must establish an audit committee. Existing listed companies had to set-up such a committee by 1 August, 1994 (Akauntan Nasional, Nov/Dec. 1993, p. 26). The deadline was later extended to 1 October, 1994 (NST, 2 Sept. 1994). The following year, the penalties for any breach of the KLSE listing requirements, which included non-disclosure of corporate information, were upgraded from public reprimands and suspension of trading to fines of up to RM 100,000 (NST, 30 Sept. 1994). In 1993 the Securities Commission (SC) was established with the passing of the Securities Commission Bill by Parliament in October 1992 (Mohd Ariff Yusof, 1993; Mohd Salleh Majid, 1993). The SC is given the task of promoting the modernisation and ensuring orderly development of the capital market in Malaysia. In 1995, the government embarked on a series of actions to deepen the capital market, unveiling an 18-point liberalising package. This package includes various strategies to liberalise the fund management industry, lower its transaction costs, widen the local participation, relax the monetary restrictions on banks and companies and strengthen the market's regulatory framework. The objective is to ensure Malaysia meets its financial needs and provides a competitive environment to attract foreign financial institutions to site their regional base in Malaysia. The ultimate aim is to help Malaysia to take a leading role and develop as a "regional capital market centre" (Deputy Prime Minister Speech, 22 June 1995).

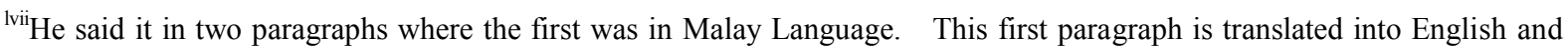
appears in the form of the first two lines of his quoted remark.

lviii Exception perhaps may be found in the small publication made available to the public in 1987 ! See Central Bank (1987).

${ }^{\text {lix }}$ The World Bank (1993, p. 226) has also noted that in this regard, based upon a recent study by Stiglitz in 1993, the situation was the same as in the developed economies where their equity markets too did not play dominant role in capital formation.

${ }^{1 x}$ It however does not mean that when shareholders are a dominant source of corporate funds, the opposite would take place for accounting. This is due to some extent to the fact that the stock market may not be active: people or institutions rarely trade their shares.

lxilxilxi This number may be contrasted with just about 4,000 in 1963 (Business Times, 24 Apr. 1997), 66,105 companies in 1980 (NST, 13 Nov. 1992) and 201,705 companies in 1990 (Business Times, 18 Sept. 1996). 